


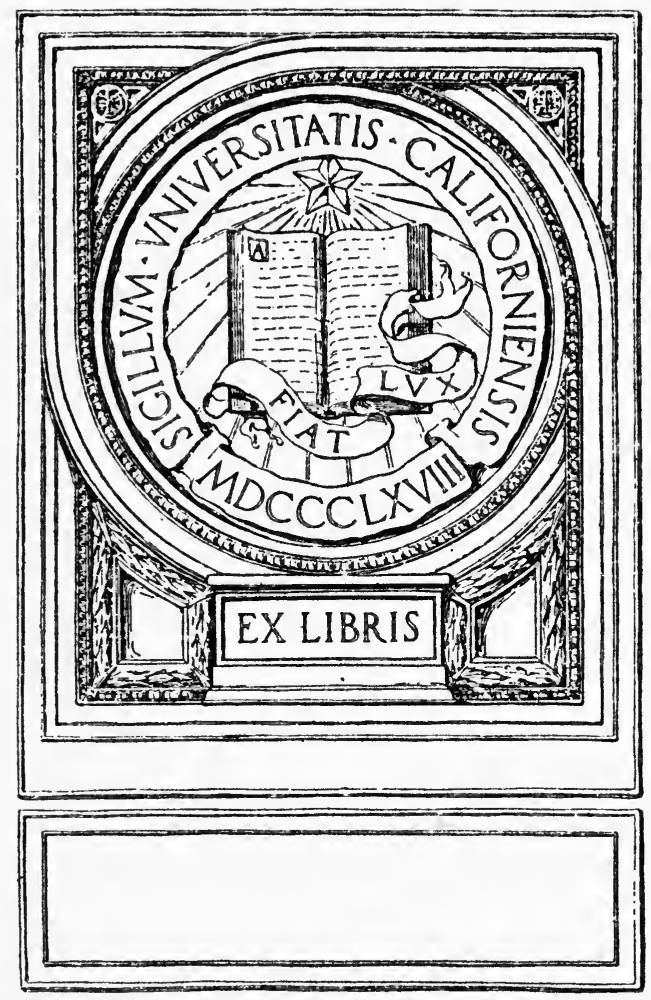




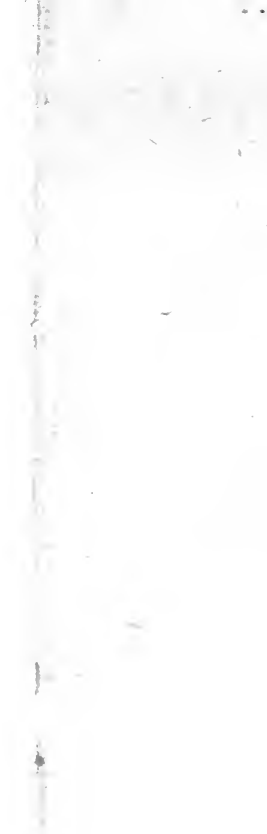

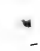



JOHN ROSS AND THE CHEROKEE INDIANS 
TO

THE MEMORY OF MY MOTHER 



\section{JOHN ROSS AND THE CHEROKEE INDIANS}

RACHEL CAROLINE EATON, A.M.

The Collegiate

GEORGE BANTA PUBLISHIṆG COMPANY MENASHA, WISCONSIN

I9I4 


$$
\begin{aligned}
& \text { EQ } \\
& . C 52
\end{aligned}
$$

Copyright, 1914, By

George Banda Publishing Company Publishers

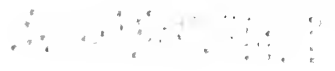




\section{FOREW ORD}

There is no more tragic history than that of the Cherokee Indians. The steady growth and development of this group of aborigines living among the mountains of Georgia, North Carolina and Tennessee is interesting as showing their capacity for building a culture of their own. Landowners, masters of negro slaves, inventors of an alphabet of their own and organizers of an adequate civil government, they offered from the close of the American revolution to the advent of Andrew Jackson, a unique example of Indian life. And what is more important to the student of the politics of the United States the Cherokees proposed to form a state of their own after the manner of the other states of the Union. This bold proposition raised many problems: What would the people of Georgia do if the United States refused to guarantee the integrity of her boundaries? What would the Federal Supreme Court answer to a petition under the treaties with the national government for local authority and self-government inside the bounds of one of the original thirteen states? And if the Georgians and the Indians came to blows what would be the effect of Federal intervention?

Thus we see that the history of the Cherokee Nation offers a good opportunity to any student who has sympathy for the natives and a proper sense for the realities of the American national development. Mrs. Eaton in her Life of John Ross, about whose career centers most of the story of the Cherokee exploitation and sorrowful removal to Oklahoma, has touched upon or answered most of these questions, and her story is presented clearly and in most interesting manner. The book ought to find many readers.

University of Chicago,

William E. Dodd

September 30, 1914. 


\section{PREFACE}

In the written records of America the place accorded the aboriginal peoples who once ruled over the whole western world can scarcely be considered a reputable one. The very name Indian is a misnomer due to a geographical error of the fifteenth century which enlightened knowledge has failed to correct.

On the pages of United States history the Indian usually appears seated at the council fire grimly plotting the destruction of his enemy, or formidable in feathers and war paint, tomahawk in hand, he lurks darkly on the outskirts of civilization awaiting an opportunity to fall upon defenseless pioneers whose scalp he can display as proof of his prowess. That he has ever cherished any but sinister sentiments for those who dispossessed him of his birthright or that he has exercised any but destructive influences upon the history of the country has been too often ignored. It is even denied that he is capable of Anglo-Saxon civilization.

Nevertheless it true that some of the most eminent physicians, eloquent preachers, prominent authors, astute financiers and constructive statesmen in America today are of this same aboriginal stock.

The aim of this historical sketch is to trace the evolution from barbarism to civilization of one of the most progressive tribes of North American Indians; to give a sympathetic interpretation of their struggle to maintain their tribal identity and ancestral domains against the overwhelming tide of economic development advancing from the Atlantic seaboard westward; to relate the story of their forcible removal to the western wilderness where in the midst of hard-won prosperity they were plunged into the horrors of the Civil War. John Ross by reason of his chieftainship of nearly four decades, was the most interesting of several able men of this tribe.

In the preparation of the book abundant use has been made of the manuscripts placed at my disposal by the Sequoyah Historical Society of Claremore, Oklahoma, of the Payne Manuscripts in the Ayer Collection of the Newberry Library, Chi- 
cago, and of the manuscript letters and records in the United States Indian Office.

I am also deeply indebted to Mr. Leon C. Ross and Mr. Robert L. Ross of Tahlequah, Oklahoma, for the free use of their rare collections of letters and documents: to Mr. A. S. Wyley for information on Cherokee education, and to Mr. Andrew Cunningham and Colonel J. C. Harris for access to the Cherokee National records at Tahlequah.

To Professor Edward M. Sheppard of Drury College, who first encouraged me to take up the study of Indian history, I owe sincere thanks. To Professor William E. Dodd, of the University of Chicago without whose helpful suggestions and unfailing interest the book would never have been completed, I desire to express my special gratitude. For a critical reading of the manuscript I am under obligations to Professors A. C. McLaughlin, Frances W. Shepardson and Frederick Starr of the University of Chicago.

In addition to those mentioned there are others whom I wish to thank for assistance rendered and encouragement given. Among these is Mrs. Frances J. Moseby, my late colleague at the Industrial Institute and College of Mississippi.

Lastly, if the background of the story adds anything to the merit of the book the credit is due to Mrs. Lucy Ward Williams, one of the last of the fireside historians of her race, whose vital interest in her people constrained her to repeat their story in season and out of season until it was rooted and grounded in my memory from earliest childhood. 


\section{CONTENTS}

Page

Chapter I

The Youth and Early Training of John Ross ....... 1

Chapter II

Early History of the Cherokees ............. 7

Chapter III

John Ross Beginning his Public Career .......... 23

Chapter IV

Georgia's Growing Demand for Indian Land . . . . . . . 39

Chapter V

Georgia's Hostility to the Cherokees .......... $4{ }_{47}$

Chapter. VI

The Cherokees Adopt a Constitution .......... 52

Chapter VII

The Removal Bill .................... 60

Chapter VIII

Factional Strife $\ldots \ldots \ldots \ldots \ldots \ldots \ldots \ldots \ldots \ldots \ldots$

Chapter IX

The National Executive Refuses Protection to the Indians

Chapter $\mathrm{X}$

The Annuity Plot $\ldots \ldots \ldots \ldots \ldots \ldots \ldots \ldots \ldots .63$

Chapter XI

The New Echota Treaty ............... 92

Chapter XII

Opposition to the Treaty ............... 100

Chapter XiII

Compulsory Removal .................. 110 
Chapter XIV

The Trail of Tears ................... 121

Chapter XV

A Triple Tragedy .................. 126

Chapter XVI

Political Readjustment ................. 136

Chapter XVII

Political Readjustment, Concluded ............ 148

Chapter XVIII

Two Decades of Economic Development .......... 161

Chapter XIX

The Civil War ................... 174

Chapter XX

The Civil War, Concluded ............... 188

Chapter XXI

Reconstruction of the Cherokee Nation ......... 198

BIBLIOGRAPHY $\ldots \ldots \ldots \ldots \ldots \ldots \ldots \ldots .210$ 




\section{CHAPTER I}

\section{'T'me Youth and Early Training of John Ross}

Few men of aboriginal American stock have figured more conspicuously in United States history or have been the subject of more diverse opinions than has John Ross, who, for nearly forty years, was chief of the Cherokee Indians.

Beginning his political career when Georgia was commencing to assert her extreme views in regard to the Indian question, he was considered by Georgia statesman and border politician as "a silent and a sordid man,"1 dangerous and obnoxious, to be feared for his influence over the Indians and hated because he was absolutely incorruptible. To the majority of the Cherokees he was a Solomon in the council and a David in the defense of their rights. Between these extreme opinions were those of such men as Clay, Webster, and Marshall, who considered him a cultured and an honest gentleman, the peer of many who sat in the legislative halls at Washington. Even his bitterest enemies conceded that he possessed ability of no mean order.

His qualities of leadership early forced him into the forefront of the conflict which, for almost two decades, waged so bitterly in Georgia and on the borders of Tennesssee and Alabama, and which finally terminated in the expatriation of the Cherokees. In the new nation which they organized beyond the Mississippi he was again at the head of government, which position he held until his death, just after the close of the Civil War.

Tracing the lineage of John Ross, we find that he inherited his white blood from sturdy and eminently reputable Scotch stock, while his Indian ancestors were prominent clansmen of the Cherokees, this most progressive tribe of North American aborigines. His maternal grandfather was John McDonald, born at Inverness, Scotland, in 184\% As a youth of nineteen McDonald visited London, and there falling in with another young Scotchman who had just engaged passage to America, he decided to go with him and try his fortunes in the New

${ }^{1}$ Cong. Doc. 315, No. 120, p. 573. 
World. They landed in Charleston, South Carolina, in 1766. McDonald soon made his way to Savannah where he secured a clerkship in a mercantile establishment which carried on a thriving trade among the Indians. His business judgment and steady habits inspired his employers with such confidence that they sent him to Fort Loudon on the Tennessee near Kingston, ${ }^{2}$ to open up and superintend trade among the Cherokees. It was not long until he set up in business for himself and married Ann Shorey, a half-blood Cherokee woman.

In the early days of colonization, when a white man married an Indian woman, it was the custom among the Indians to adopt him into the tribe if he was deemed worthy of such honor; thereafter he cast his lot among his adopted people, adapting himself to their customs and becoming identified with their interests. So John McDonald, to all intents and purposes, became a Cherokee of the Cherokees, and when a band of them encroached upon by the white settlers and out of sympathy with the garrison at Fort Loudon, left their homes and pushed out into the wilderness of northwest Georgia, he went with them and settled near Lookout Mountain. It was here he met, under most romantic circumstances, Daniel Ross, another Scotchman, who was destined to play a larger part than his countryman in the affairs of the Cherokees.

Daniel Ross was originally from Sutherlandshire, Scotland. In his childhood he had gone with his parents to America in the latter half of the eighteenth century. They settled in Baltimore where Daniel was left an orphan at the close of the American Revolution. Like many another young man of the time the West so appealed to him that he accompanied a Mr. Mayberry to Hawkins County, Tennessee, where they built a flatboat, filled it with merchandise and started down the Tennessee to the Chickasaw country to trade in furs. Their route led them through the most hostile part of the land of the Cherokees, and when the party reached the town of Sitico on the Tennessee River near Lookout Mountain, their appearance caused considerable excitement among the natives. The whole community turned out at once eager to know the design of the

${ }^{2}$ Tennessee. 
strangers. Upon investigation it was found that, in addition to valuable merchandise, the party had on board a hostile chief named Mountain Leader. Bloody Fellow, a Cherokee chief, counseled the massacre of the whole party and a confiscation of their property. A division of opinion having arisen concerning this course, John McDonald, who lived fifteen miles away, was summoned to give his advice on the subject. Arriving on the scene of excitement he investigated the nature of the party and, finding its object a legitimate one, urged that no harm be done the strangers. He also warned Bloody Fellow that any injury done the white men would be considered a personal affront to him. Not only were the traders released, but they were invited to remain and establish a trading post in that country, and the invitation was accepted. ${ }^{3}$

Daniel Ross soon afterwards married Mollie McDonald, daughter of John McDonald, a woman said to possess rare beauty of face and charm of manner. During the next twenty years he travelled in different parts of the Cherokee Nation, establishing trading posts and conducting successful business enterprises. He was a man of irreproachable character and sturdy honesty, with the same code of ethics for red man and white, and gradually he came to wield a considerable influence among the Cherokees.

Of the nine children of Mollie and Daniel Ross, John, the third son, was born at Tahnoovayah, on the Coosa River, in 1790. He grew up for the most part like any other little Indian boy of the time in the free, outdoor life of the tribe in the beautiful hills and valleys of the Cherokee Nation, enjoying all the sports and undergoing all the hardships of Indian life.

When he was about seven years of age he accompanied his parents to Hillstown to attend the Green Corn Festival, an annual thanksgiving feast held in the spring when Indian corn was in the roasting ear. For several days the clans gathered from the hills and valleys of all parts of the nation and gave themselves up to feasting and ball playing, religious ceremonies, and social intercourse. John Ross's mother on this occasion p. 293.

${ }^{3}$ McKenney and Hall, Indian Tribes of North America, Vol. III, 
had dressed him in his first suit of nankeen brand new made after the white man's style, and he sauntered out to meet his playmates with all the self-consciousness of one wearing, for the first time, his new spring suit. But if he expected to be surrounded immediately by admiring and envious playmates he was doomed to disappointment. Shouts of derision and taunts of "Unaka!" greeted him on all sides; even his most intimate friends held aloof. Although the day was a most unhappy one he stood staunchly by his new suit until bedtime. But while being dresssed by his grandmother the next morning he burst into tears and after much coaxing told her of his humiliation of the day before. She comforted him as grandmothers are wont to do the world over. Promptly the nankeen suit came off, the hunting shirt, leggins and moccasins went on, and the small boy ran shouting to his play happy and "at home" again, as he termed it, warmly welcomed by his dusky clansmen who had "boycotted" him the day before.

About the time of this incident the problem of educating his children began seriously to concern Daniel Ross. There were no schools in the Cherokee Nation and, because of hostility between the Indians and backsettlers, there was great hesitancy on the part of conservative chiefs to adopt any European customs. A few of the more progressive members of the tribe, however, were beginning to realize that in order to cope successfully with the white man they must understand his language, customs and laws. The broader policy prevailed in the great council to which Ross presented a request to establish a school on his own premises, ${ }^{5}$ and import a schoolmaster. The request was granted. John Barber Davis was employed as teacher, and the school, started about the end of the eighteenth century, was the beginning of a new era in the history of the tribe. It was in this school and under this schoolmaster that John Ross laid the foundation for good English, both oral and written, which in his later life often astonished statesmen, baffled politicians, and served him well in his long career in Cherokee national affairs.

4 White man.

'Daniel Ross was now living at Maryville, Tennessee, about six hundred miles from his former residence. 
When John and his brother, Lewis, were old enough they were sent to Kingston ${ }^{6}$ to attend a popular academy at that place. While here they lived in the family of a merchant, a friend of their father, and helped him in the store out of school hours. Kingston was a busy and enterprising town on the great emigrant road from Virginia and Maryland through Cunberland Gap to Nashville. At the beginning of the nineteenth century a constant stream of emigrants was pouring over this highway seeking homes in the rich valleys of Tennessee and Kentucky. Here the two Scotch Cherokee lads, coming in contact with the busy, bustling life about them, had their minds aroused to such activity that progress in their school work went by leaps and bounds, and they proved to be among the brightest scholars of the institution. They also received practical training as clerks in the store, learning methods of business and accommodation to circumstances which proved to great advantage to them when they were ready to go into business for themselves. ${ }^{7}$

After spending two or three years at Kingston they were called home by the death of their mother to whom both the boys were particularly devoted. She was a woman of strong character and unusual intelligence, and her influence upon her children was one of the dominant factors of their lives. Herself intensely loyal to the traditions of her ancestors, she lost no opportunity of instilling these sentiments in the minds of her children. For her son John, who was the pride of her heart, she had cherished the greatest love and ambition. He was heartbroken and almost prostrated with grief at her loss and never, throughout his long life, ceased to cherish her memory.

When the brothers, John and Lewis, grew to manhood they set up in business for themselves at Ross's ${ }^{8}$ Landing in company with John Meigs. ${ }^{9}$ Their business prospered and the young men enjoyed the reputation for sobriety and honesty, which their father had established before them.

- Tennessee.

'McKenney and Hall, p. 296.

${ }^{8}$ Now Chattanooga, where he finally located.

${ }^{\circ}$ Son of R. G. Meigs, Indian agent for the Cherokees. 
John developed into an especially attractive young man of medium height and slender, supple figure. His eyes were blue and his hair was brown. He is said to have looked like a typical Scotchman, though he manifested many Indian traits of character. He possessed a quiet, reserved manner and a personality which inspired everyone with confidence and respect.

When still a youth he took an active interest in the affairs of the tribe, and the older men discussed with him freely the problems which were interesting and puzzling them at this time. He thus began at an early age not only to be interested in the development of the Cherokees into the greatest nation of civilized Indians, but to have a vital part in that development.

In order to have a better understanding and appreciation of his character it is necessary at this point to take at least a rapid survey of the history of the Cherokee Indians up to this time. 


\section{CHAP'TER II}

\section{Early History of the Cherokees}

At the beginning of the nineteenth century the Cherokees were the most powerful and the most civilized of all the North American Indians. Their possessions, which at one time extended from the eastern slope of the Blue Ridge Mountains almost to the Mississippi and from northern Kentucky to central Alabama and Georgia, though greatly diminished, still covered a territory of fifty-three thousand square miles, almost half of which lay in Tennessee, a small area in southwestern North Carolina, the rest being about equally divided between Alabama and Georgia. They were the mountaineers of the south holding the mountain barriers between the English settlements on the Atlantic Seacoast and the French and Spanish garrisons in the Mississippi Valley and on the Gulf Coast.

They called themselves Yun-wi-yah, meaning principal people. The name Cherokee, or Cheraqui has been given more than one interpretation. According to one version it is a contraction of two words meaning "He takes fire." It was believed by the Spaniards to signify rock-dwellers, and was probably given them by neighboring tribes as descriptive of their mountain country, ${ }^{2}$ which according to Bancroft, was the most picturesque and salubrious region east of the Mississippi. "Their homes are encircled by blue hills rising beyond blue hills of which the lofty peaks would kindle with the early light and the overshadowing night envelop the valleys like a cloud." David Brown, a Cherokee youth educated at Cornwall, Connecticut, writing in 1822, describes it as a well-watered and fertile region; "Abundant springs of pure water are to be found everywhere," he says. "A range of lofty and majectic mountains stretch themselves across the nation, the northern part of which

${ }^{1}$ This probably originated in the belief that at the Creation the Great Spirit gave the tribe a sacred fire which was to be kept perpetually burning.

${ }^{2}$ Mooney, Myths of the Cherokees. 19th. Rep. Bureau of Ethnology, Vol. I, p. 15.

Bancroft, History of the United States, Vol. II, p. 95. 
is hilly while in the southern and western parts are extensive and fertile plains, covered partly with tall trees through which beautiful streams of water glide. The climate is delightful and healthy; the winters are mild and the spring clothes the ground with richest verdure. Cherokee flowers of exquisite beauty and variegated hues meet and fascinate the eye in every direction."

Cradled in such surroundings it is not strange that the Cherokees were instinctively artistic and responsive to every form of natural beauty. The song of bird and the delicate fragrance of wild flower delighted, while the massive grandeur of mountain and forest filled with awe and admiration these children of the wilderness, often inspiring their minds to lofty flights of fancy which sometimes found expression in metaphors of exceeding subtlety and beauty.

Attachment to their ancestral homes was strong and sincere and had its root deep in the past of their domestic and religious institutions. As is always the case when a primitive people has dwelt for a long time in the same region their legends had become localized and were associated with mountain peak and prominent rock and tree, with spring and cave and deep riverbend.

'The English traveller Bartram describes the people of this tribe as of larger stature and fairer complexion than their southern neighbors. "In their manner and disposition they are grave and steady; dignified and circumspect in their deportment; rather slow and reserved in their conversation, yet frank, cheerful and humane; tenacious of the liberties and natural rights of man; secret, deliberate and determined in their councils; honest, just and liberal, and ready always to sacrifice every pleasure and gratification, even their blood and life itself, to defend their territory and maintain their rights." 5 The men are described as tall, erect and moderately robust; their feaures regular and their countenances open, dignified and placid, exhibiting an air of magnanimity, superiority and rude independence; The women as tall, slender, erect and of delicate frame; their features formed with perfect symmetry; their

4 American State Papers, II, p. 651.

${ }^{5}$ Bartram, Travels through North and South Carolina and Georgia, etc., pp. 366-368 (1792). 
"countenance cheerful and friendly; they move with a becoming grace and dignity.",

They were a religious people: but "never in their most savage state did they worship the work of their own hands, neither fire nor water." They believed in a Great First Cause, in a spirit of Good, and a spirit of Evil in constant warfare with each other, the Good finally prevailing. Heaven, an open forest of shade and fruit trees, was adorned with fragrant flowers and mossy banks beside cool sparkling streams; game abounded and there were enough feasts and dances to satisfy but not to cloy the appetite for pleasure. This happy and immortal region reserved for beautiful women, prepared and adorned by the Great Spirit, and men distinguished for valor, wisdom and hospitality, lay just across the way from the land of Evil Spirits, where the wretched who had failed on earth were compelled to live in hunger, hostility and darkness, hearing and seeing the rejoicings of the happy without the hope of even reaching the delectable shores.

Witches and wizards were abroad in the land, who professed supernatural powers and were supposed to have intercourse with evil spirits and to have the power of transforming themselves into beasts and birds in which forms they took nocturnal excursions in pursuit of human prey, usually, though not always, those stricken with disease. The croak of a frog or the hoot of an owl in the twilight was enough to strike terror to the heart of the bravest Indian child who verily believed that the witches "would get him if he didn't watch out."

Adair, who for forty years was a trader among the southern Indians and travelled extensively through their country between 1735 and 1775 describes the Cherokees as living in villages situated beside "cool, sparkling streams," in which they bathed frequently, either as a religious rite or for the purpose of "seasoning" the body and rendering it indifferent to exposure.

Ibid.

${ }^{7}$ John Ridge to Albert Gallatin, 1826. Payne Mss. 8.

${ }^{8}$ John Ridge to Albert Gallatin. Payne Mss. 8.

${ }^{9}$ Adair, J., History of the American Indians, pp. 224-226. 
"They are almost as impenetrable to cold as a bar of steel," he declares. ${ }^{10}$

Their villages lay in four main groups $:^{11}$ the Lower Settlements lying upon the head streams of the Savannah; the Middle Settlements on the Tennessee and its southern tributaries; the Valley Towns west of them between two ranges of the Blue Ridge Mountains; and the Overhill Settlements on the Little Tennessee between the Blue Ridge and Holston. Besides these main groups were scattered towns situated in different parts of the Cherokee country. It was estimated in 1735 that there were sixty-four towns and villages, "populous and full of women and children,"12 with about sixteen or seventeen thousand souls all told, over six thousand of whom were warriors. Each village had its council house and its outlying fields of maize, beans and squashes, the common property of the community. The head man of the village, together with certain warriors distinguished for prowess, not only managed local affairs but represented the village at the General Council of the Nation usually held ${ }^{13}$ at Chota $^{14}$ on the Tellico River. A certain loose tribal unity was maintained by a principal chief and by certain laws or regulations by which every member of the tribe was bound.

To summarize, the Cherokees, by virtue of their location had developed an artistic temperament, certain physical and mental characteristics and a form of religious belief in keeping with and influenced by their surroundings. Because of this intimate relation their attachment to their country was exceedingly strong, a fact important in the explanation of their later actions, but often either overlooked or disregarded by the ever encroaching whites.

Contact of the Cherokees with Europeans dates back to the middle of the sixteenth century when the daring and adventurous De Soto marching northward from Tampa Bay and

${ }^{10}$ Ibid, p. 226.

${ }^{11}$ Each village having its own peculiar dialect.

${ }^{12}$ Adair, p. 227.

${ }^{13}$ Before 1785.

${ }^{14}$ The Ancient peace town or "City of Refuge." 
passing over "rough and high hills" arrived in the land of the Cheraqui. The Spaniards described the Indians as a naked, lean and unwarlike people given to hospitality to strangers. To the travellers they presented baskets of berries and presents of corn, wild turkeys and an edible species of small dog which latter the Cherokees themselves did not eat, according to the Gentleman of Elvas. ${ }^{15}$

From time to time the Cherokees met Spanish explorers and English and French settlers from whom they gradually adopted such civilized arts as appealed to them. That they so long remained conservative to European ideas and appeared to disdain anything alien was due to the fact that there was so little in civilization that appealed to people in the barbarous stage, and not to their lack of intellectual vigor. Their own tools and implements were so admirably suited to their purposes that they did not feel the need of better ones. Fire arms proved an exception. The Indian learned their use readily for by them he was enabled to supply the growing demand of furs, the chief article of trade with Europeans, and to hold his own with his enemies. By 1715 about twelve hundred Cherokee warriors were supplied with guns, and a few years later the governor of South Carolina furnished two hundred more with guns and ammunition on condition that they would help him in a war upon a neighboring tribe. ${ }^{16}$

Before the end of the seventeenth century Virginia and South Carolina traders began dealing with the Cherokees. In 1690 Cornelius Daugherty, a Virginia Irishman, established himself among the tribe with whom he spent the remainder of his life. He was followed by other traders, some of whom were not on the very best terms with the aborigines, due chiefly to their custom of purchasing or capturing Indians to be sold in the settlements or to the West Indies, and to their general conduct toward the natives which was described as sometimes "very abuseful."17 Complaints of these abuses coming from

${ }^{15}$ The Gentleman of Elvas. Publication of the Hakluyt Society IX, pp. 52, 58, 64 .

${ }^{16}$ Haywood, Natural and Aboriginal Tennessee, p. 227. Fire arms were first introduced among them about 1700 .

${ }^{17}$ Hewat, A., Historical Account of the Rise and Progress of the Colonies of South Carolina and Georgia, Vol. I, pp. 297, 298. 
the Cherokees to Governor Nicholson, coupled with the jealousy of French encroachments upon English trade with the Indians, caused him to arrange for a conference of chiefs to be held at Charleston in 1721. A treaty establishing a boundary between the Cherokees and the settlement was agreed upon; a chief was designated as the head of the nation to represent it in all dealings with the Colonial Government; a commissioner was appointed to superintend the relation of the colony with the Cherokees and a small cession of land was made, ${ }^{18}$ the first in the long list that was to follow.

Nine years later we find North Carolina commissioning Sir Alexander Cummings to arrange a treaty of alliance with the tribe. After a preliminary meeting with the chiefs on the Hiwassee in the Cherokee country he conveyed a committee of six of them, bearing the crown of the nation, to England where after a visit of several weeks they signed the treaty of Dover. The treaty provided that the Cherokees trade with no other country than England, and that none but Englishmen be allowed to build forts or cabins, or plant corn among them. ${ }^{19}$ In return for these concessions the chiefs carried home a generous supply of paint, a few pounds of beads and some other equally worthless articles. Flattered by the courteous treatment which they received in England they did not at first realize the disproportionateness of the bargain.

These two treaties were but the beginning of land cessions by which, year after year, from this time on, under one pretext or another, the aborigines were shorn of their ancestral domains and found themselves powerless to prevent it.

In 1755, a treaty and purchase of land were again negotiated by South Carolina. ${ }^{20}$ In 1756 North Carolina commissioned Hugh Waddel to conclude a treaty of alliance and cession which was followed up the same year by Governor Glenn's p. 144.

${ }^{18}$ Ibid; Royce, Cherokee Nation. 5th Report of Bureau of Ethnology,

${ }^{19}$ Hewat, A., Historical Account of the Rise and Progress of the Colonies of South Carolina and Georgia, Vol. II, pp. 3, 9, 11. The crown of the nation consisted of five eagle tails and four scalps. It is otherwise known as the "War Bonnet."

${ }^{20}$ Ibid. 
chain of military forts, Fort Prince George erected on the Savannah, Fort Monroe $\mathbf{1 7 0}$ miles farther down the river and Fort Loudon on the Tennessee at the mouth of the Tellico. ${ }^{21}$ In 1777 Cherokee hostilities were put down with a heavy hand by the combined forces from Virginia, North Carolina and South Carolina and most of their principal towns on the Tennessee destroyed. ${ }^{22}$ A cession ${ }^{23}$ of land was wrung from the Indians which proved so distasteful to the Chicamauga band that they refused to assent to it. Moving westward they settled the "Five Lower Towns" on the Tennessee, among which was Lookout Mountain town where Daniel Ross came so near losing his life. With various other treaties these bring us to the end of the official relations of the Cherokees with Colonial Government so far as concerns land cession and to the War of Independence and the formation of the Confederation.

The mother country and her colonies by failing at the outset to adopt a definite systematic policy of justice and humanity towards the Indians established the precedent for all subsequent dealings with them. Charters and patents granted by England to the Colonies neglected to give due consideration to the prior claims of the aboriginal tribes. The colonies left their course with the Indians to be directed by circumstances. Agents and commissioners were given a free hand in securing land cessions and arranging treaties. Bribes were used without scruple and chiefs and headmen corrupted by every available means. 'That any advantage which might be taken of the ignorance and misunderstanding of natives unfamiliar with the English language was considered legitimate is evident to any one familiar with the history of Indian treaties. Neither governments nor individuals considered it dishonest to cheat an Indian, criminal to rob him nor murder to kill him. Any attempt to protect him or to teach him the way of salvation was scarcely deemed meritorious. That amicable relations existed at all between the Indians and the English was due to two causes: first, the few exceptional white men who looked upon the savage as entitled to the same justice and humanity as that to which the white

${ }^{21}$ Martin, North Carolina, Vol. II, p. 87.

${ }^{22}$ American State Papers, Indian Affairs, Vol. I, p. 431.

${ }^{23}$ At Dewitt's Corners; Haywood's History of Tennessee, p. 451. 
man is entitled; and second, to the increasing proximity of Spaniards in Florida and French in the Mississippi Valley and on the Gulf Coast, bidding for Indian trade. These the English watched with jealous eye, dreading not only the loss of profitable trade but the hostility of the natives who could become formidable enemies at the very back doors of the settlements.

This fear caused the Colonists to adopt a conciliatory policy toward the Cherokees who, responding to their advances, formed an alliance with them against the French. In the attack upon Fort Duquesne a band of Cherokee warriors rendered valuable service to the English. The contemptuous attitude of British and Colonial officers, the severe military restraint placed upon them, suspicion of their fidelity together with various other reasons, caused them to become dissatisfied and return home. Having lost their horses in an encounter with the French and being fatigued by the long journey, they supplied themselves with mounts from a herd which they found running at large on the frontier. The inhabitants of Virginia, horrified at this act of horse stealing, attacked the warriors on their way home through the settlements and killed forty of them. An act of treachery on the part of a settler who invited a party of Cherokees to his house in order that they might be surrounded and shot down as they left his hospitable roof completed the estrangement. Ata-Kulla-Kulla, a prominent chief, calling a council of war declared that after they should have safely conducted back to the settlements some Englishmen who were among them for the purpose of arranging a treaty, "the hatchet shall never be buried until the blood of our people shall be avenged." "But let us not violate our faith," said he, "by shedding the blood of those who have come among us in confidence bearing belts of wampum to cement a perpetual friendship. Let us carry them back to the settlements and then take up the hatchet and endeavor to exterminate the whole race of them." ${ }^{24}$ In the bloody war which followed villages were burned, orchards and maize fields destroyed, women and children murdered, many warriors slain, and the remaining inhabitants

${ }^{24}$ McKenney \& Hall, History of the Indian Tribes of North America, Vol. III, p. 343 (1855). 
forced to take refuge in the caves of the mountains until peace was restored by the humiliating treaty of $\mathbf{1 7 6 0}$.

The tribe had not fully recovered from the effects of this struggle when they were confronted with the War of Independence. Smarting under their recent defeat and resenting the steady encroachment of colonists upon their hunting grounds, they promptly ranged themselves on the side of the British and placed their warriors at the service of King George. In the border warfare which followed, Indians and whites vied with each other in the atrocity of their deeds. The Cherokees, finally completely defeated, were forced to sue for peace in $\mathbf{1 7 8 5}$. By the terms of the treaty of Hopewell which followed, Congress was to pass laws regulating trade with them; the Cherokees were allowed to send a delegate to Congress and no whites were to be suffered to settle upon Cherokee lands. ${ }^{25}$ This treaty was unsatisfactory to Indians and whites alike. The latter paid scant attention to the article forbidding them to settle on Indian lands; the natives refused to submit to the encroachment of the settlers and kept them terrified by sudden raids and bloody massacres. The whites retaliated in kind and this condition of affairs kept up until stopped by intervention of the Federal Government in $\mathbf{1 7 9 0 .}$

As early as 1789 General Knox, Secretary of War, called the attention of President Washington to the disgraceful violation of the treaty of Hopewell and recommended the appointment of a commission to look into the matter and, if need be, negotiate a more effective treaty. ${ }^{26}$ In August of the next year the Senate passed a resolution providing for such a commission and the result was the treaty of Holston which, in addition to settling the boundary question, gave the Federal Government the exclusive right to trade with the Cherokees, granted an annuity of $\$ 1000$ and promised to supply implements of husbandry and send four persons into the Cherokee Nation to act as interpreters. ${ }^{27}$

An Indian agent who was sent to see that the policy of the treaty was carried out established headquarters on the Hi-

${ }^{25}$ Amer. State Papers, Indian Affairs, Vol. I, p. 953.

${ }^{2}$ Ibid, p. 52.

${ }^{27} 7$ U. S. Statutes at Large, p. 62; Cong. Doc. 531, No. 28, p. 148. 
wassee River near where it empties into the Tennessee and from this point settled disputes between the whites and Cherokees, enforced intercourse laws, apportioned annuities and distributed plows, hoes, spinning wheels, cards and looms among the Indians and instructed them in their use. Colonel Silas Dinsmore, ${ }^{28}$ who was agent from 1796 to 1799 devoted his energies to the raising of cotton, to which some sections of the nation were excellently well suited. Major Lewis succeeded him and was succeeded in turn by R. J. Meigs, an old Revolutionary soldier, who had marched to Quebec with Arnold. For twenty-two years he served as Indian agent rendering efficient and intelligent service and acquiring a knowledge of the character and needs of the Cherokees which made him authority in their affairs ${ }^{29}$ as long as he lived.

This new policy of the Federal Government gave encouragement, impetus and direction to the progressive spirit already abroad in the nation. Notwithstanding the half century of intermittent warfare the Cherokees had made considerable advancement before the treaty of Holston. Adair states that horses had been introduced among them early in the eighteenth century and that by 1760 they had a prodigious number of them and they were of excellent quality. The same may be said of cattle, hogs and poultry. Sevier on his expedition against the Coosatowns in $\mathbf{1 7 9 3}$ allowed his army to kill three hundred beeves at Etowah and leave their carcasses rotting on the ground. ${ }^{30}$ Benjamin Hawkins while travelling through the Cherokee Nation three years later met two Indian women driving ten fat cattle to the settlements to sell. ${ }^{31}$ Indian pork was highly esteemed by the Colonists; "At the fall of the leaf" says Adair, "the woods are full of hickory nuts, acorns, chestnuts and the like, which occasions the Indian bacon to be more streaked, firm and better tasted than any we met with in the English settlement." ${ }^{\text {32 }}$ Baskets were made by the women and pottery of simple though pleasing design was moulded from

${ }^{28}$ Payne Mss. 8, Ridge to Gallatin, 1826; also Payne Mss. 5, extract from Journals of the Moravians.

${ }^{20}$ Royce, Cherokee Nation, p. 231.

${ }^{30}$ Mooney, Myths of the Cherokees, p. 82.

${ }^{31}$ Ibid.

${ }^{32}$ Adair, p. 230. 
clay and glazed by holding in the smoke of corn meal bran $;^{33}$ hunting was a lucrative occupation of the men until the end of the nineteenth century, a party of traders taking home at one trip thirty wagon loads of furs.

By their geographic position and superior numbers, the Cherokees might have held the balance of power in the south had it not been for the looseness of their tribal organization. The first attempt to weld the whole nation into a political unit was in 1736 when Christian Priber, a French Jesuit, went to live among them and, by promptly adapting himself to their language and dress, won their confidence to such an extent that he was able to induce them to adopt a scheme of government which he drew up, modelled on the French monarchy, with the chief medicine man as emperor, himself as secretary of state, and Great Tellico as the national capital. ${ }^{34}$ But when Priber was arrested by the authorities of North Carolina on the accusation of being a secret emissary of the French, this scheme gradually went to pieces. It was seventy-two years later that they reorganized their government and adopted their first code of written laws. In $\mathbf{1 8 0 8}$ the Council provided for the organization of regulating parties to maintain order in the nation, named the penalty for horse stealing and declared that fatherless children should inherit the father's property in case the mother married again. ${ }^{35}$ It had been the custom among the Cherokees, time out of mind, to transmit from father to son the memory of the loss by violence of relatives or members of the clan. With the memory also was transmitted the obligation to revenge the loss. "Who sheddeth man's blood, by the clansmen of the deceased shall his blood be shed," was considered good savage ethics; but the Cherokee Nation emerging from barbarism had outgrown this ancient custom, and in 1810 an act of oblivion for all past murder was passed by unanimous consent of the seven clans in council at Oostinaleh; ${ }^{36}$ punishment was taken from the clan and placed in the hands of the

${ }^{3}$ Payne Mss. 6, p. 61.

${ }^{34}$ Adair, pp. 240, 243.

${ }^{35}$ Amer. State Papers, Indian Affairs, II, p. 282.

${ }^{26}$ Ibid, p. 283. 
General Council. The later development in government will be taken up and treated in a future chapter.

With the exception of the work done by Priber and the Federal Government no outside aid had heen given the Cherokees and no effort was made to civilize or Christianize them before the end of the eighteenth century. A writer of the times declares that, "to the shame of the Christian name no pains have ever been taken to convert them to Christianity., ${ }^{, 37}$ On the other hand their morals were perverted by contact with some of the worst vices of the white man: chief of these was intoxicating liquors, which wrought sad havoc with the tribe corrupting morals and government until strict laws were passed by the Council prohibiting its importation under a penalty of forfeiture to natives and forfeiture and a fine of $\$ 100$ for outsiders. Indeed it has proven a curse and a blight to these Indians even down to the present generation.

The first mission station in the Cherokee Nation was established in 1801 by the Moravians and grew out of a desire on the part of the Cherokees to educate their children rather than eagerness to embrace a new religion. This peaceful sect of German Christians had established a settlement on the Upper Yadkin about 1752. During the Indian Wars Cherokee chiefs who had been hospitably received by them expressed a desire that teachers be sent to their people and the evangelizing of that tribe had never been lost sight of by the Brethren. ${ }^{38}$ In 1799 two missionaries from this place visited the Cherokees to investigate the question. As a result the next year a Council was held at Tellico Agency and after much discussion in which considerable opposition was expressed permission was granted the missionaries to start a school. The Rev. Abraham Steiner and Gottlieb Byham began to hold religious services in the home of David Vann, a mixed-blood Cherokee of progressive ideas, but on account of various difficulties the school was not started promptly. At the Great Council held at Oostinaleh a few miles distant, it was declared that the Cherokee Nation wanted edu-

${ }^{87}$ Mooney, Myths of the Cherokees, p. 38; Carroll's Hist. Collections of South Carolina, II, pp. 97-8, 517 (1836).

${ }^{38}$ Thompson, A. C., Moravian Missions, p. 341; Amer. State Papers, Indian Affairs, I, p. 282. 
cators, not theologians, and unless the missionaries could open a school within six months they should leave the Nation. With the encouragement of Agent Meigs and the assistance of Vann and Charles Hicks the school was finally built, Vann donating a part of his farm as a location, lodging the missionaries while the mission was building and lending substantial aid in the construction of the house. The school was opened in due time and the children of some prominent chiefs soon enrolled as students. In 1805 Reverend and Mrs. John Gambold took charge at Spring Place where they remained until her death fifteen years later.

In 1804, the Presbyterians followed the Moravians and established a school at Maryville, Tennessee, with the Reverend Gideon Blackburn at its head, while the American Board of Foreign Missions established in $1817^{39}$ the famous Baptist School at Brainard Mission from which Missionary Ridge took its name. A great religious revival swept over the country beginning about $1818,{ }^{40}$ but up to this time there were remarkably few conversions to the Christian religion, those of Catherine Brown, the first Cherokee convert, Margaret Vann, wife of David Vann, and Charles Hicks, later to become for a short time Principal Chief of the Nation, being the most notable.

The missionaries worked side by side with their pupils their instruction being thus practical as well as theoretical and industrial as well as religious. 'They in this way gained a very strong hold upon the natives, and their influence among them for good is not easily estimated. To them is due in large part the splendid school system which the Cherokees were able to build up and maintain in after years in the wilderness beyond the Mississippi.

Intermarriage of the Cherokees with Europeans dates back to early colonial times. Until the end of the eighteenth century it was confined chiefly to white men, but after that time several white women married into the tribe. The intermarried white men were usually traders or officers and soldiers of the frontier forts with a few men from the back settlements and were of

${ }^{29}$ Gude, Mary B., Georgia and the Cherokees, p. 24.

${ }^{40}$ Ibid, p. 23. 
good English, Scotch, Irish or Huguenot stock. The Dougherties, Vanns, Rogers, Gunters, Wards and McDonalds are among their descendants. By the beginning of the nineteenth century the mixed population with civilized ideas was one of the dominant political forces among the Cherokees which made itself felt in the reorganization of the government from 1808 to $182 \%$.

The opening of highways in the Indian country was another tremendous influence for civilization, though, like most other innovations of the white man, they were bitterly resented by the conservative Indians. But by 1816, however, treaties had been arranged ${ }^{41}$ permitting the opening of all roads necessary for intercourse between Tennessee, Georgia, and the territory lying directly west of them for the convenience of travellers. For the same purpose general stores and public houses of entertainment were built at intervals along these roads which proved a source of considerable income to the owners, who were natives of the nation. The opening of highways through this country brought the whole nation more closely in touch with the outside world and by stimulating trade and encouraging the accumulation of property prepared the way for further developments. ${ }^{42}$

Negro slavery also had its part in the history of the development of the Cherokees. The first of the slaves were runaway negroes from the Virginia and Carolina settlements whom the Indians appropriated to their own use in cultivating their fields. ${ }^{43}$ They proved so profitable that others were bought from the settlers from time to time and slavery gradually became a settled institution of the tribe. In their relations with their slaves it is to the credit of the Cherokees that their treatment of them was so humane that slaves preferred living in the nation to residence in the United States; and that there was rarely ever an intermixture of Cherokee and African blood. ${ }^{44}$ In 1825 there were one thousand two hundred and seventy-seven negro slaves in the Cherokee Nation. ${ }^{45}$ By their

${ }^{41}$ Cong. Doc. 531, No. 28, p. 148; Amer. State Papers, Ind. Aff., I, p. 649; Royce, Cherokee Nation of Indians, p. 187; Amer. State Papers, I, p. 698; 3 U. S. Statutes at Large, p. 139.

${ }^{42}$ Morse, Indian Reports, Hicks to Calhoun, 1822.

${ }^{43}$ McKenney \& Hall, Indian Tribes of North America, Vol. III, p. 331.

${ }^{44}$ Amer. State Papers, Indian Affairs, II, p. 651. Letter of David Brown.

${ }^{45}$ Ibid. 
help farming, especially the raising of cotton, developed more rapidly than it would have done under native labor, and more leisure and opportunity for culture were given to both men and women.

The beginning of the westward emigration among the Cherokees is shrouded in legend and tradition. The story of the Lost Cherokees indicates that a part of the tribe migrated beyond the Father of Waters at a very early time. It is probable that bands of hunters visited the western prairies at intervals before the discovery of-America by Europeans. Wars with the settlers, discontent over land cessions and intrusion of whites upon their domains led small bands to migrate into Spanish territory where a settlement was made on the St. Francis River in Arkansas $;^{46}$ later they removed to a tract of land between the Arkansas and the White Rivers, and in 1803 came under the control of the Federal Government.

Jefferson, in order to validate the Louisiana Purchase and justify himself in the eyes of his strict construction constituents, thinking he saw light in the direction of Indian removal, drew up a rough draft of a constitutional amendment which had for its central idea the removal of all the Indian tribes to the newly acquired territory. ${ }^{47}$ On his recommendation an appropriation of $\$ 15,000$ was made by Congress as the preliminary step towards bringing about this result. ${ }^{48}$ When, in 1808, a delegation of Cherokees was about to visit Washington to ask for an adjustment of their differences and a more equitable distribution of annuities, the Secretary of War wrote Agent Meigs to embrace every occasion for sounding the chiefs on the subject of the removal of the whole tribe. $^{49}$ A considerable difference existed at this time between the Upper and Lower Cherokees; the former were chiefly farmers while the latter, still hunters, were beginning to feel themselves hedged in by the narrowing boundaries of their hunting grounds. Differences of opinion growing out of these

${ }^{48}$ Payne Mss. 2, 71.

${ }^{47}$ Abel, Indian Consolidation, Chap. 1.

${ }^{48}$ Royce, Cherokee Nation of Indians, pp. 202, 203.

- Indian Office Manuscript Records, Secretary Dearborn to Agent Meigs, March 25, 1808. 
differences in occupations led to discontent. In May, 1808, a delegation of Upper Cherokees arrived in Washington, requesting that a line be drawn between their lands and those of the Lower Cherokees, that their lands be allotted them in severalty, and that they be admitted as citizens of the United States, while their brethren in the South might hunt as long as the game lasted. In his talk with them Jefferson encouraged removal, but informed them that citizenship could not be conferred upon them except by Congress ${ }^{50}$ The next year or two the idea of removal seems to have gained favor with both Upper and Lower Cherokees. An appropriation having been made for the purpose a delegation was sent out to investigate the Arkansas country and returned with such favorable reports that a large number was prepared to move at once. Jefferson went out of office, however, before anything could be accomplished and Mr. Madison was not in favor of removal on a large scale. Although by $181 \%$ between 2000 and $3000^{51}$ had emigrated, the emigration was not officially countenanced either by the United States or their own Nation. ${ }^{52}$ Other delegations went to Arkansas in 1818 and 1819 and still later, even to within a short time before the New Echota Treaty of 1835. These Cherokees constituted what were later called Old Settlers. In this way there came to be a Cherokee Nation East and a Cherokee Nation West.

This survey of Cherokee history will furnish a partial idea of the conditions in the Cherokee Nation when John Ross, was growing to manhood, and beginning to enter upon the duties of a citizen of the Cherokee Nation.

\footnotetext{
${ }^{50}$ Jefferson's Works, Library Edition, XVI, 432-435.

${ }^{51}$ Royce, p. 204.

${ }^{52}$ Amer. State Papers, Indian Affairs, II, pp. 97, 125.
} 


\section{CHAPTER III}

\section{John Ross Beginning His Public Career}

It chanced that John Ross, though peculiarly devoted to the interests of his own people, the Cherokees, nevertheless rendered his first public services to the Federal Government, as the following incidents will prove.

During the years just preceding the War of 1812 the Indian question assumed unusual importance at Washington. The Southern tribes were still strong enough, if united by Tecumthe's plan of a Southern Confederacy, to cause considerable trouble should they choose to renew their allegiance with Great Britain. Frequent reports reached the War Office that agents of the British Government were arming the Indians of the Great Lakes and the Western frontier and encouraging hostilities to the United States. ${ }^{1}$ A war with England and an uprising on the frontier at one and the same time appeared doubly embarrassing to a government poorly equipped for fighting in either direction. In order to conciliate the Indians and attach them as strongly as possible to the American cause, the Secretary of War instructed Indian agents to promote and maintain friendly relations with the Indian tribes ${ }^{2}$ and at the same time furnished them the means of carrying out this policy. Gifts to prominent chiefs, medals for services to the Federal Government, appointments in the army, a friendly interest in their tribal affairs, all tended to have the desired effect upon the Southern tribes. This was true particularly of the Cherokees, whose agent, Colonel R. J. Meigs, was one of the wisest and most efficient men who has ever served the United States and the Indians in the capacity of agent. The Eastern Cherokees were enjoying unprecedented prosperity and were rapidly taking on civilized manners and customs; consequently, they favored peace. To make sure of the band in Arkansas, the agent dispatched an interpreter to them bearing gifts as peace offerings. The interpreter, alarmed by rumors of an

${ }^{1}$ Indian Affairs, I, 797-804.

${ }^{2}$ Circular letter from Department of War to Southern Agents, June 20, 1805, Indian Office Manuscript Records. 
earthquake at New Madrid, returned home. Colonel Meigs, thereupon, asked John Ross, then a young man about nineteen years of age, to undertake the mission. On Christmas day he set out from Ross's Landing armed with additional gifts and accompanied by John Spier, a half-breed, Kalsatchee, an aged Cherokee, and Peter, a Mexican. The boat which carried the party was a rude craft entirely unsuited to such a journey. Isaac Brownlow, ${ }^{3}$ a famous frontiersman of his day, swore, on meeting the party, that Colonel Meigs was either stupid or careless to send an inexperienced young fellow on a long expedition in such a plight. He accompanied them eighty miles down the river and on leaving them exchanged his good keel boat for their "clapboard ark" taking an order on the government for the difference, and declaring that he would rather lose his boat than see Ross risk making the journey as he had started. After sixty days upon the rivers in dead of winter, chased by warlike Indians who thought they were whites, and suspicious settlers who thought they were an Indian party on mischief bent, they wrecked their boat, lost the greater part of their baggage and were compelled to finish the way on foot. Often up to their knees in mud and water and with only such game as they could kill for food, they covered the remaining two hundred miles in eight days.

From start to finish the story of the expedition fairly bristles with stirring adventures and hairbreadth escapes; it even rivals in interest that of the American hero so dear to the heart of every schoolboy. Late in April the party reached Ross's Landing from whence they had started, and were able in a short time after to report to Colonel Meigs at the agency the success of the expedition. ${ }^{4}$

The next two or three years were comparatively uneventful ones for young Ross, spent at his father's home at Rossville or on trading trips to different parts of the Cherokee Nation. These trading trips gave him opportunity to become acquainted with the conditions of the country and brought him in contact day.

${ }^{3}$ Brother of Parson Brownlow, both well known in Tennesse in their

4 McKenney and Hall, Indian Tribes of North America, Vol. III, p. 298 (1870).

${ }^{5}$ Now Chattanooga. 
with many of the more backward members of the tribe as well as with leading chiefs. Always quiet and unassuming and always scrupulously honest in his dealings, he won confidence and respect wherever he was known. The intimate knowledge of country and people acquired during these years was destined to be of infinite service to him later on.

When Tecumthe made his tour through the south and with his burning eloquence and his "almanac of red sticks" tried to fire the southern tribe to revolt against the United States he met with cool courtesy among the Cherokees. A few of the mountain chiefs expressed a desire "to dance the war dance of the Indians of the Lakes and sing their song," but thanks to the influence of Major Ridge, a progressive and influential chief of whom we shall hear more later, the war spirit was promptly quenched in the council of the tribe. ${ }^{6}$ When the General Council assembled they decided that, as there would be more loss than gain to them from an alliance with either of the contending parties, they would remain neutral. Thereupon, the Red Sticks, as the war party of the Creeks was called, perpetrated outrages upon the Cherokees which aroused such indignation among the young warriors, already eager to test their prowess in battle, that the Council abandoned its peace policy, declared war upon the hostile Creeks and placed their forces at the command of the Federal Government. Between seven hundred and eight hundred warriors under their own officers took part in the Creek war and rendered valuable services to the American cause.

Ross promptly enlisted in a regiment raised to coöperate with the Tennessee troops, was appointed adjutant and set out to the Creek country where he served with distinction in several engagements. He took a prominent part in the battle of Horse Shoe Bend, where it was undoubtedly the bravery and daring of the Cherokees and loyal Creek forces that won the victory for General Jackson which rendered him a military hero and prepared the way for his promotion, a few years later, to the highest rank in the American army. The battle took

'McKenney and Hall, Indian Tribes of North America, Vol. II, pp. 93, 94 (1855). 
place on the Tallipoosa River about two miles from the site of the present village of Tohopeka, Alabama. The Creeks had thrown up a strong fortification of logs across the neck of the peninsula, made by a bend in the river, and behind it about a thousand warriors and three hundred women and children had taken refuge. Moored to the river bank behind them were their canoes to be used in case retreat became necessary. ${ }^{7}$ When it was found that General Jackson with his artillery was making no headway on the breastworks, John Ross, ${ }^{8}$ with several other Cherokees, plunged into the river, swam to the peninsula at the risk of their lives and brought off the canoes. In these the Cherokee forces crossed the river and attacked the Creeks in the rear. This diverted the attention of the Creeks from the front and Jackson succeeded in storming the fort. They fought desperately, but were cut down without mercy. Of the three hundred who survived in the fort only three were men. The defenders of the Horse Shoe were practically exterminated. Some of the Cherokees lived to rue the part they took in this inhuman massacre. "If I had known Jackson would drive us from our homes I would have killed him that day at the Horse Shoe,"9 said Junaluska, an aged chief, many years after.

On his mission to the Western Cherokees Ross had shown energy, tact, prudence and perseverance in prosecuting and bringing to a successful close a difficult undertaking. In the Creek war he had proved himself a fearless soldier. What more was needed to give him prestige with the tribe and a place among the foremost men of the Cherokee Nation? Moreover, he was a man of education according to the standard of the time and could meet white men on their own ground. It is not surprising, therefore, to find his name in the list of delegates who went up to Washington in the winter of 1816 to protest against the action of commissioners sent to carry out the provisions of the treaty of Fort Jackson which came at the close of the Creek war. General Jackson, who was appointed one of the commissioners to arrange the treaty, showed scant con-

${ }^{7}$ Pickett's Alabama, pp. 58-591 (Reprint of 1896).

${ }^{8}$ Congressional Globe, 2nd Session, 25th Congress, p. 404.

${ }^{\ominus}$ Drake, American Indians, p. 401. 
sideration to the loyal Creeks and the Cherokees. From the former he demanded the cession of the Hickory Grounds comprising more than half the territory of the Creek Nation and when they demurred, told them to sign the treaty or join their kinsmen who had fled to Florida. General Coffee, detailed by General Jackson to survey the lines limiting the cession on the north and west, encroached upon the claims of the Cherokees. When they objected he promptly made a private contract with Richard Brown, a Cherokee chief through whose village the lines ran. ${ }^{10}$ The Cherokees, protesting against the action of the commissioners, sent a delegation of seven men to Washington to lay the matter before the Secretary of War. Agent Meigs accompanied them. Notwithstanding the efforts of General Jackson who was in Washington at the time the delegation arrived to prejudice the Secretary of War against them, they secured an interview, stated their case and convinced Mr. Crawford of the justice of their claim. The result was the negotiation of the treaty of Washington in which the boundary lines were satisfactorily established and a claim of two thousand five hundred dollars for damages during the Creek war was allowed the Cherokees. ${ }^{11}$ General Jackson was greatly chagrined over the success of the delegation and his intense hatred of Crawford is said to date from this incident. ${ }^{12}$ He was naturally no friend to the Indians, though he did not hesitate to accept favors from them when occasion arose, and his determination to rid the southern states of them was strengthened by his temporary embarrassment and humiliation. From this time forward he and his friends managed to secure more and more of the Indian patronage and their influence on the War Department tended steadily and persistently towards the ultimate aim, removal.

The delegation to Washington in 1816, consisting of Colonel Lowrey, Major Walker, Major Ridge, Adjutant Ross

${ }^{10}$ To these proceedings Gen. Jackson gave such eager support as to cause suspicion that he and Gen. Coffee were personally interested in the new land. Abel, p. 279, note.

${ }^{11}$ March 22, 1816. 7 U. S. Statutes at Large, p. 139; Indian Treaties, pp. 185-187 (1837).

${ }_{12}$ Parton, Life of Jackson, p. 356. 
and Cunnessee, show that the Cherokees were no longer a savage nation to be dealt with after the fashion of former times. "These men are men of cultivation and understanding," says the National Intelligencer in mentioning their arrival. "Their appearance and deportment are such as to entitle them to respect and attention."

The fact that the Indians were becoming civilized and showed evidence of the ability to develop into good American citizens, thereby adding strength to the whole American nation, did not appeal to politicians who coveted Indian lands. In truth this class of men opposed any policy for civilizing the Indians, since it would tend to attach them more firmly to the soil. And to many a white man just over the border the Indian country was the promised land of wealth and plenty which he hoped some day to possess. If the delegates returned home with the belief that their territorial boundaries were permanently fixed they were soon undeceived.

Soon after his return from the Creek war, John Ross, in partnership with Timothy Meigs, ${ }^{14}$ had started a general store at Rossville, and in the autumn of 1816 he went to New York to buy goods. With a supply of deerskins and furs for traffic he went by way of Savannah to New York and Baltimore, where he bought the stock of shawls, calicoes, implements and such other articles as were in demand among the Cherokees at this time. While absent, reports reached him through the newspapers, of a commission appointed at Washington for the purpose of negotiating a treaty with the Cherokees, the object of which was to secure their consent to remove west of the Mississippi. The Tennessee contingent in Congress had been urging the President to free that state of Indians. ${ }^{15}$ Governor McMinn had an agent in the Cherokee Nation all winter campaigning for removal. The Arkansas Cherokees were having trouble with the Osages and the Quapaws, ${ }^{16}$ as no definite tract

${ }^{19}$ Niles' Register 10, p. 16.

${ }^{14}$ Son of Agent Meigs. He died soon after this and Mr. Ross's brother Lewis succeeded him in business.

${ }^{15}$ Abel, Indian Consolidation, p. 280; Crawford to Meigs, May 27, 1816, Indian Office Letter Manuscript Records.

${ }^{16}$ Niles' Register 13, p. 74. 
of land had been assigned to them nor was likely to be without a corresponding cession in the east. They appealed to Washington. President Monroe, relying upon reports sent the War Office the previous summer by General Jackson, then among the southern tribes, concerning the willingness of the Cherokees to emigrate, appointed a commission, ${ }^{17}$ which was to meet the Cherokees at the Agency, June 20, 181\%. The Spring Council of the Cherokees met in May at Amohe. The news of the impending negotiations had gone abroad and men and women turned out in full force, as was the custom, to hear the discussions in the council and perhaps have a voice in them. ${ }^{18}$ Ross decided to attend merely as an observer. At Spring Place he met Judge Brown, a prominent man of the tribe and a member of the National Committee, a branch of the Cherokee legislative body. As they rode on together Judge Brown jestingly remarked that they were going to put Ross in purgatory when he arrived at Amohe. When the young merchant expressed objections to such a fate Judge Brown explained that he meant they were going to run him for a member of the National Committee. He was not entirely unprepared, therefore, when soon after the council was convened he was called in and Major Ridge, speaker of the Council, announced to him that he had been appointed a member of the National Committee. ${ }^{19}$

The discussions in the council revealed strong opposition, not only to removal, but also to the cession of any more land. "If the western band was not happy where they were let them return to the eastern nation," was an argument heard on all sides. If there had been a sentiment for removal the previous year as Jackson had affirmed, there was no evidence of it at this time. When the commission arrived at the Agency, June 20, only representatives from Arkansas were present to meet them, and it was three weeks before a sufficient representation could be obtained to open negotiations. The Arkansas members who had everything to gain and nothing to lose were weather.

${ }^{17}$ Composed of General Jackson, Governor McMinn and General Meri-

${ }^{18}$ The chiefs never conclude a very important business before they find out the popular sentiment of their people. Agent Meigs to Secretary of War, Nov. 8, 1816. American State Papers, Indian Affairs, II, p. 117. (1870).

${ }^{10}$ McKenney and Hall, Indian Tribes of North America, Vol. III, p. 299 
graciously compliant; the Eastern Nation firmly opposed removal or a cession of territory. In a talk which he made to them General Jackson took the ground that the Cherokee delegation of 1809 had arranged with President Jefferson for an exchange of lands east of the Mississippi River for lands west of it, and that the time had now come when the exchange must be made. In order to fix the boundaries of the western country so as to prevent white people from settling within them it was necessary for all who expected to remove at any future time to declare it now, as after the bounds were marked and the lands laid off they would not otherwise be allowed to settle there. The United States would provide the means for removing to those who wished to go and to the poorer classes would furnish implements of husbandry, arms and ammunition for hunting and would allow them reasonable compensation for improvements. Those who preferred to remain might do so by becoming citizens of the United States. "As free men you have now to make your choice," he declared. "Those who go west go to a country belonging to the United States. There your father, the President, can never be urged by his white children to ask their red brothers, the Cherokees, for any of the lands laid off at that place for them." As for the eastern lands he declared that the right of possession or hunting was the only right guaranteed to the Cherokee Nation by former treaties. ${ }^{20}$

The Cherokees chose Elijah Hicks, and John Ross to frame a reply to the commissioners. Going into the forest they drew up a memorial with careful deliberation, Ross doing the writing. 'This memorial having been signed by sixty-seven chiefs was presented by the council to General Jackson. It stated that the great body of the Cherokees desired to remain in the land of their birth where they were rapidly advancing in civilization. They did not wish to revert to their original conditions and surroundings. They prayed, therefore, that the question of removal be pressed no farther and that they be allowed to remain peaceably in the land of their fathers. ${ }^{21}$ No attention was paid to the memorial and a treaty prepared by General

${ }^{20}$ Jackson's Talk to the Cherokees, 1817. Payne Mss. 7, 31-44.

${ }^{21}$ Payne Mss. 7, p. 45. 
Jackson was signed by the Arkansas representation and by twenty-two of the chiefs, though not the most representative ones, of the Eastern Nation who were susceptible to Jackson's influence.

Great preparations were promptly started to incline the Cherokees to removal. A special agent was sent to assist $\mathrm{Mr}$. Meigs and when the work still did not go fast enough to suit Governor McMinn, he himself went to the Nation and canvassed for emigrants. Although bribes passed freely and intimidation was unsparingly used ${ }^{22}$ to get Indians to come in and enroll for removal, the governor of Tennessee, who was notoriously self-interested in the project, was doomed to disappointment in the final results. By the last of June about seven hundred had enrolled and several boats were ready to descend the river bearing them to the western country. ${ }^{23}$ But they did not represent the sentiments of the nation. The Cherokees as a body were opposed to emigration and as the summer wore away, hostility towards the treaty became more and more bitter. Those who enrolled were ostracized and in some cases cruelly persecuted. The council which met in the fall deposed and deprived of any further authority in the tribe Toochelah, the Second Chief. It took his commission from him and appointed in his place Charles Hicks a leader in the opposition party. The body even went further and passed the resolution that, "We consider ourselves a free and distinct nation and the National Government has no polity over us further than a friendly intercourse in trade," ${ }^{24}$ thus setting forth the earliest formulation of their opinion concerning their political status, a question which was to be settled more than a decade later by a decision of the Supreme Court. ${ }^{25}$

So active was the opposition to the treaty that when a delegation of twelve Cherokees appeared at Washington in $1819^{26}$ Secretary Calhoun entered into a new treaty which effectually put an end to removal for the time being. By it

${ }^{22}$ Cong. Doc., 98, No. 127, pp. 52-82 (18th Cong.).

${ }^{23}$ Niles' Register 13, p. 74, Letter of Agent Meigs.

${ }^{24}$ Exec. Doc. 98, No. 127, p. 76.

${ }^{25}$ In the Case of Cherokee Nation vs. Georgia.

${ }^{28}$ Niles' Register 16, p. 158. 
the Cherokees agreed to cede to the United States a tract of land at least as extensive as that to which it was entitled under the treaty of 1817 and consented to the distribution of annuities in the proportion of two to one in favor of the eastern nation; the United States agreed to dispense with taking the census of the treaty of $181 \%$, and obligated itself to remove intruders from the Cherokee Nation. ${ }^{27}$

John Ross was a member of this delegation and faithfully stood guard over tribal, as opposed to personal, interests. After the first draft of a treaty had been arranged, Major Walker, one of the delegation, with a view to "feathering his own nest" proposed an additional grant of land to be made in such a way as to benefit him personally but to cause distinct loss to the Cherokee Nation. Ross saw through this scheme and promptly thwarted it, much to the chagrin of Walker, who, however, said nothing at the time. The night before the party was to leave Washington, Ross was writing at a late hour in his room which was also occupied by his brother Lewis and James Brown, who had already retired. Elijah Hicks occupied the adjoining room. Judge Martin, another member of the delegation, seeing a light in the room as he returned from the theatre, went in and was giving Mr. Ross an account of the play when suddenly the door was opened and in rushed Walker with eyes glaring and face flushed, a brickbat in one hand and a drawn sword in the other. Rushing upon Ross he shouted, "I am come to whip you!" at the same time flinging the brick at him and narrowly missing his head. Ross, who had tilted back in his chair to avoid the missile, slipped and fell just as Walker was upon him with his sword. Quick as a flash he was on his feet, knife in hand ready to strike blow for blow when both men were seized and separated by Judge Martin and Lewis Ross. Ross was thrust through the door into the next room, while the drunken Walker was hustled off to his own quarters and put to bed. The two men met at Baltimore the next day, but neither then nor ever after mentioned the incident. They met afterwards as if nothing had happened and so the unfortunate

${ }^{27} 7$ United States Statutes at Large, p. 195. 
affair died away. Walker from then on drank more heavily and gradually lost his prestige among his people. ${ }^{28}$

The Cherokees now earnestly addressed themselves to further national improvements. Their hopes and ambitions ran high. In a circular letter to the adjoining states in 1813, they declared that many of their youth of both sexes "had acquired such knowledge of letters as to show the most incredulous that our mental powers are not, by nature, inferior to yours, and we look forward to a period of time when it may be said 'this artist, this mathematician, this astronomer is a Cherokee"!"29 There was an increasing desire among them to have their children educated. The treaty of 1819 contained a provision for a reservation of land twelve miles square to be sold by the United States, the proceeds to be invested by the President in stocks and bonds and the income applied in the manner best calculated to promote education among the Cherokees east of the Mississippi. ${ }^{30}$ In 1822 seven Cherokee boys were being educated in a mission school at Cornwall, Connecticut. Of these John Ridge, Elias Boudinot and Richard Brown were to play a prominent part in the politics of their nation.

In 1817 missionary activities among the southern tribes increased. In less than ten years they had eight churches and thirteen schools among the Cherokees. These schools were very well attended. Children were taught not only reading, arithmetic and writing but also the agricultural arts. "In the latter," says one who visited the Cherokee Nation in 1818, "the boys take the different branches in weekly rotation; and on Monday morning such as are to turn out to labor are called by naming their avocations of labor, as plow boys, hoe boys, axe boys, to which call they answer and appear with the greatest cheerfulness and alacrity. The girls are taught in

${ }^{28}$ Payne Mss. 2, p. 450.

${ }^{29}$ Niles' Register 4, p. 125.

${ }^{20}$ Niles' Register 26, p. 102. 
similar method, their occupations being suited to their sex. They are instructed in the use of the needle, the art of spinning, knitting and all household business and it is stated that among them are some gentle young women who would not disgrace more polished society. "31 While progress in the academic branches was slow at first the industrial training met with eager interest and wrought such results that village life was almost completely abandoned, the inhabitants scattering out and taking up farms. As the land was held in common a farm was in reach of any member of the tribe who had the energy to clear it and put it in cultivation. By 1822 most families cultivated from ten to forty acres and raised corn, rye, oats, wheat and cotton. The women spun and wove their own cotton and woolen cloth and blankets and knitted all the stockings used by their families. ${ }^{32}$

By 1826 the mass of the Cherokees lived in cabins, some of which were built of hewn logs and were floored and furnished with chimneys, while well-to-do slave owners built comfortable two-story houses, some of which were really elegant, and were living in much the same style as the white planters of the same economic standing in the south. Except in remote mountain regions, the hunting shirt, leggings and moccasins, along with old customs and religion, were fast disappearing under the influence of commerce, education and missionary zeal. "It no longer remains a doubt," wrote a missionary from Brainard, Tennessee, as early as 1812, "whether the Indians of America can be civilized. 'The Cherokees have gone too far in the pleasant paths of civilization to return to the rough and unbeaten track of savage life." ${ }^{33}$

Political advancement kept pace with economic and educational progress. By 1820 the government was well organized and administered. It had undergone considerable change since its organization in 1808. The Light Horse, or Regulators, provided for at that time served their purpose well and were not dispensed with until 1825 when district officers made their ser-

${ }^{81}$ Niles' Register 14, p. 390.

${ }^{32}$ Payne Mss. 6 and 7; Morse, Indian Report, Hicks to Calhoun, 1822.

${ }^{23}$ Niles' Register 20, p. 102. 
vices no longer necessary. In 1815 the Council provided for a standing committee whose business it was at first to look after claims and adjust financial differences. This committee, appointed by the Council of Chiefs for two years, developed into the upper house of the legislature, while the General Council became the lower house. Thus was a bicameral system worked out by an aboriginal tribe groping towards the light of a civilized form of government. The former body, composed of thirteen members including its president with a clerk to record its proceedings, had the power, as it was later developed, to control and regulate financial affairs, inspect the treasurer's books $^{34}$ and to acknowledge claims. The council under the old system had been large and the responsibility of each chief trifling. In $181 \%$ it was reorganized; useless members were stricken off and a standing body of legislators was created. This body was to assemble in October of each year at New Echota, hereafter to be the permanent seat of government. By 1826 it consisted of thirty-three members including its speaker. It had power to legislate and fill vacancies in its own body and in the committee. The principal chief and second chief were elected by joint ballot of both houses. In 1820 the Council determined to divide the nation in eight districts in each of which was located a council house where court was held twice yearly. District officers administered all business purely local. A code of laws was developed regulating taxes, internal improvements, the payment of debts, the liquor traffic and marriages; the franchise was limited to Cherokee citizens and punishments were defined for crimes and misdemeanors. ${ }^{35}$

In 1819, on the removal of John McIntosh, John Ross became president of the National Committee which position he filled successfully for eight years. With other prominent and progressive men of the Cherokee Nation he recognized that in order to realize their national ambition the Cherokees must maintain their tribal unity and integrity. In order to prevent

${ }^{34}$ A treasurer was first appointed in 1819 to take charge of annuities. Payne Mss. 2, p. 379.

${ }^{35}$ Payne Mss. 2, p. 379, Letter of Ridge to Gallatin, 1826; also, Vols. 6 and 7; American State Papers, Indian Affairs, II, 279-283; McKenney's Letter, Ibid, p. 657 ; Drake's Indians, pp. 437, 438 (1880). 
a repetition of the treaty of 1817 the Council adopted a resolution making it a death penalty for individuals to sign a treaty ceding Cherokee land. Further cession must be made by the National Committee and the National Council acting together. It appears that in 1826 the organization of the government had been pretty thoroughly accomplished and the tribe was not unprepared for the next step which was taken by the council in its resolution providing for a convention to draw up a written constitution. They were laying large plans also for improving educational facilities: a national library was under contemplation and the best method of establishing a Cherokee national school system was being discussed by such Cherokee citizens as Major Ridge, Major Walker, Elijah Hicks, the Vanns and the Rosses, all considered men of ability and refinement even in Washington.

An event occurred in 1821 which profoundly influenced the whole future history of the tribe. A young mixed-blood Cherokee, known among the whites as George Guess and among his own people as Sikwayi, invented the Cherokee alphabet. Of the father of Sequoyah very little is definitely known. On his mother's side he was of good family, being a nephew of Oconostota, a famous war chief of pre-Revolutionary times. His early youth was spent at Chota, ${ }^{36}$ the ancient peace town of the Cherokees, amid the bloody scenes of Indian wars during the Revolution. He never attended school and never learned to read, write or speak the English language. Like most Indian youths of his time he hunted and trapped and lived a wild, free life among his native mountains and valleys. Possessed of considerable mechanical skill, he liked especially to work in silver. When about forty years of age a chance conversation called his attention to the white man's ability to communicate thought by means of writing. Naturally of a contemplative turn of mind he reflected upon the possibility of working out a similar system for his own people and finally determined to attempt it. After years of patient effort, in spite of repeated failures and the discouragement and the ridicule of friends and relatives, he finally evolved a Cherokee syllabary, which was so simple and so remarkably adapted to the language that in order to ${ }^{2}$ Near Fort Loudon. 
read and write it was necessary only to learn the eighty-six characters of which it was composed. The mass of the people immediately recognized its possibilities and in a few months thousands who could not speak English and had despaired of acquiring an education were learning to read and write in their own tongue. With one accord the whole Cherokee Nation seemed to resolve itself into a great Indian academy, old men and children as well as the youth and the middle-aged, addressing themselves to the mastery of the system. As soon as one had learned it he taught another. Thus almost every fireside became a school and every man, woman and child, either teacher or pupil. Even at the post office, in the public houses, or by the roadside, instruction was given and received, "so that within a few months without school or other expense of time or money, the Cherokees were able to read and write in their own language. ${ }^{937}$

When, three years later, by an act of the National Council, a printing press was set up at New Echota and the Cherokee Phoenix, a weekly paper printed in both English and Cherokee, was started with Elias Boudinot, just returned from school in Cornwall, Connecticut, as editor, the most illiterate members of the tribe were able to read the proceedings of their legislative body and keep in touch with the progress of their nation. Soon the Bible was translated into Cherokee, and later hymn books and textbooks followed. An active correspondence sprang up between the eastern and western nations, for Sequoyah had a true missionary zeal and carried his inventions to Arkansas where he took up his permanent abode in $\mathbf{1 8 2 3}$. In the fall of that year, the Cherokee Council, in recognition of his merits, awarded a silver medal bearing a commemorative inscriptions in both languages. ${ }^{38}$ The president of the National

${ }^{37}$ McKenney and Hall, Indian Tribes of North America, I, p. 46 (1858).

${ }^{38}$ Indian Treaties, p. 425 (1837). A very interesting account of the life of Sequoyah written by a full-blood Cherokee, translated into English by another Cherokee and passed upon by a Committee of the National Council is found in Payne Mss. 2, pp. 224-249.

- Other accounts are found in Mooney's Myths of the Cherokees, pp. 107110; Phillip's Sequoyah, Harper's Magazine, September, 1870, pp. 542-548; Pilling, J. C., Bibliography of Iroquois Languages, pp. 72, 73; Foster, Sequoyah, (1885). 
Committee was commissioned to bear this token of regard to him and once more John Ross crossed the Father of Waters and journeyed to his tribsmen on the Arkansas. While his second mission was not attended with as many wild adventures and harrowing experiences, as was the one made fourteen years earlier, it was full of interest and importance as it gave him opportunity to investigate the nature of the country and the condition of the people in the territory to which the Federal Government had been offering many inducements to the Eastern Cherokees to remove. That his impressions of the country were not favorable is evidenced by the fact that he returned home to use every effort for strengthening the government and welding the Cherokees into a strong, united nation in order that they might present a solid front of resistance to any further project for removal. 


\section{CHAPTER IV}

\section{Georgia's Growing Demand for Indian Lands}

Georgia, meanwhile, as her population increased and spread from the coast plain up the fertile river valleys, year by year pushing back the line of the frontier further into the highlands, found an ever growing demand on the part of her citizens for the removal of the aborigines. The Creeks and Cherokees, particularly, they regarded as serious obstacles to progress. By 1823 demand for their removal from the state had become insistent. The Federal Government in 1802 had entered into an agreement with Georgia to extinguish, for the use of Georgia, the Indian title to land lying within the state as soon as it could be done on peaceable and reasonable terms. ${ }^{1}$ A select committee, of which George R. Gilmer ${ }^{2}$ was chairman, submitted a report to the House of Representatives on January 7, 1822, on the question whether or not the United States was keeping her part of the compact. It was the opinion of the committee that she was not so doing. ${ }^{3}$ As a matter of fact the largest Indian cessions had been obtained in other states, where, as soon as the natives relinquished their title to the land, it became part of the public domain. Acting on the report of the Gilmer committee, Congress appropriated $\$ 30,000$ for the extinguishment of Indian land titles within the limit of Georgia and Calhoun promptly appointed a commissioner to negotiate with the Cherokees for a cession of a part or all of their eastern land.

The Cherokee Council, hearing of this action of Congress, passed a resolution in its autumn cession, declaring unanimously and with one voice, the determination to hold no more treaties with the United States for the purpose of making cessions of lands, being resolved not to dispose of even one foot of ground. "But upon any question, not relating to a land cession", the resolution stated, "we will at all times during the session of

${ }^{1}$ Amer. State Papers, Public Lands, I, p. 125.

${ }^{2}$ Later governor of Georgia.

'American State Papers, Indian Affairs, II, p. 257.

${ }^{4} \mathrm{U}$. S. Statutes at Large, p. 688. 
the National Council at Echota, Newtown, receive the United States commissioners or agents with friendship and cordiality and will ever keep bright the chain of peace and friendship which links the Cherokee Nation and the Government of the United States." The Council sent copies of the resolutions to the Secretary of War and to the commissioners with the assurance that it would be entirely useless to put the United States to the trouble and expense of negotiating another treaty of cession. The commissioners remonstrated with the chiefs and threatened them with the indignation of the Great Father at Washington who would shake them off if they persisted in their obstinacy. ${ }^{6}$ So determined and bitter was the opposition, however, that the matter was allowed to rest until the following year. Meanwhile a vacancy having occurred at the Cherokee agency, the Secretary of War appointed to fill it Joseph McMinn whose advocacy for removal was well known. If prompted to this course by the expectation that the Tennesseean's familiarity with Cherokee affairs would prove advantageous to the commissioners in negotiating a treaty, Mr. Calhoun was reckoning amiss. The Cherokees both feared and hated the ex-governor for his disgraceful part in the treaties of 1817 and 1819.

In spite of the Cherokee resolutions of the previous year the War Department was so optimistic that aversion to cession might be "conquered by a little perseverance and judicious management" that it allowed the Board of Commissioners to be provided with about $\$ 35,000$ to aid them in conducting their negotiations. The Department also instructed them to coöperate with commissioners appointed by Georgia to press claims of that state arising under former treaties, and to proceed to the Cherokee Nation in the fall of 1823. The Federal Commissioners, Campbell and Meriweather, ${ }^{8}$ arrived at New Echota October 4, to find the Cherokee Council in regular session and representatives from Georgia already on the ground. Agent

- Payne Mss. 2, pp. 501-503.

${ }^{6}$ Ibid, p. 504.

'Abel, Indian Consolidation, p. 324; Indian Office Manuscript Records, Calhoun tc Campbell, March 17, 1823.

${ }^{3}$ Both Georgia men. 
McMinn promptly notified the Council of their arrival and was informed that the Grand Council was disposed to receive and be introduced to the Board according to the customs and ceremonies of the Cherokee Nation. Thereupon, accompanied by the state commissioners, they were conducted to the council house and presented in due form to the chiefs, the Council, and the committee in joint session. Major Ridge, speaker of the Council, addressed them in terms of congratulation and friendship and was answered by Mr. Campbell, who paid a high compliment to Cherokee civilization. After this auspicious beginning the commissioners showed no inclination to haste in opening formal negotiations. Time and deliberation were essential to the judicious expenditure of the appropriation placed at their disposal and the building up of a party in the Cherokee Nation favorable to cession. This last could be done only by detaching the more susceptible chiefs from the strong body of opposition and splitting the Council into factions. It was, therefore, somewhat to their discomfiture when they were called upon by the President of the Committee, two days later, for a full statement of their instructions from the President of the United States relating to their business with the Cherokees. After some hesitation on the part of the commissioners formal negotiations finally began and, by request of the Cherokees, ${ }^{9}$ were conducted by both sides in writing. "A novel procedure", undoubtedly it was, as Mr. Campbell observed, this "correspondence in writing conducted with a government regularly organized, composed of Indians." 10

The negotiations are remarkable for two things: first, the illogical arguments presented by the representatives of the United States; second, the ability and strength with which the Cherokees met these arguments and advanced cogent reasons why a further cession or removal could not be considered by them. The commissioners urged the plea that the white people were so cramped for land they were driven from friends and connections to foreign lands, while the Cherokees had more

- Payne Mss. 2, 505. Commissioner Campbell reported to the Secretary of War that it was the desire of both parties. The Cherokees claimed it was at their request.

${ }^{10}$ Campbell to Calhoun, Amer. State Papers, Indian Affairs, II, p. 464. 
land in Georgia than they needed; this was unjust; the Great Father of the universe intended the earth equally for his white and red children. The Cherokees replied that, as to the intentions of the Great Father, they did not know, but it was quite evident that neither individual nor nation had ever respected the principle. Meeting the arguments for removal, they declared that the unfortunate part of the tribe which had emigrated to the west had suffered severely in the new country from sickness, wars and other calamities, and many of them would return if they could do so; had it been their desire to go west they would have embraced opportunities formerly offered them; it was not their desire; they loved the soil which had given them birth and continued to nourish them. Pressed further for a cession of land, since they would not consider removal, they declared that the limits of their nation were small, embracing mountains, hills, and poor lands which could never be cultivated; the Cherokees had once possessed an extensive country; in order to gratify the wishes of their neighbors, they had granted to the President cession after cession, until their limits had become circumscribed. Experience had taught them that a small cession would never satisfy the white man. Therefore they had come to the unalterable conclusion never to part with another foot of land. ${ }^{11}$

As negotiations proceeded and the Cherokees remained firm, the talk of the commissioners grew harsh and threatening. They denied the right of the Indians to the soil they inhabited claiming that it had been forfeited by their hostilities to the United States during and after the War of the Revolution. Jackson's argument of $181 \%$, that the Indians were tenants at the will of the state within whose boundaries their nation lay, ${ }^{12}$ was then renewed.

But arguments, cajolery, threats and bribery proving of no avail the commissioners, finally reduced to desperation, determined upon a keen stroke of policy. It was a delicate business to be handled by an agent of rare ability and skill. A man who seemed to fill all the requirements was found in the

${ }^{11}$ American State Papers, Indian Affairs, II, 468-69.

${ }^{12}$ Ibid. 
person of William McIntosh, a Creek chief. He enjoyed the confidence and respect of the Cherokees who called him Beloved Brother. He frequently attended their councils, where he was always welcome, and occupied the "white bench" or seat of honor, reserved for distinguished guests. He really occupied an official position in the Cherokee councils, being a delegate from the Creek Council with the power to examine into and settle controversies arising between the two nations, an office established during earlier times when the southern tribes ${ }^{13}$ had a common agent. His appearance at Echota at this time, therefore, would excite no distrust in the minds of the Cherokees, for, although it was generally known that a spirit of peculation was abroad among the Creeks, no suspicion had as yet been attached to General McIntosh.

Council had been in session about three weeks when a messenger brought word that General McIntosh and several Creek chiefs would arrive at the council ground the following day. Preparations were promptly made to receive them with suitable distinction. Formal greetings and congratulations had barely been exchanged when the purpose of the delegation was revealed in a note ${ }^{14}$ from their leader to John Ross asking, in broken English, for his private opinion on the question of a treaty. In case Ross could see his way clear to favor it, the dusky general would promise to make the commissioners give him $\$ 2000$, and Isaac $\mathrm{McCoy}^{15}$ and Charles Hicks, each $\$ 2000$ for a present. And "no one shall know it", he assured them. He then added, "I will get you the amount before the treaty is signed, and if you have any friend you want him to receive, he shall receive". McIntosh himself was to have $\$ 7000$ for his services. ${ }^{16}$

Upon receipt of this communication Ross, hastily calling a meeting of his most trusted associates, laid the case before them. Their anger and surprise were equal to his own. After consultation a plan of action was determined upon. By revealing the plot of bribery in General Council in such way as

${ }^{18}$ Cherokee, Creek, Choctaws and Chickasaws. Payne Mss 2, p. 511.

${ }^{14}$ Bearing date of Oct. 23.

${ }^{15}$ Clerk of the Council.

${ }^{16}$ Payne Mss. 2, p. 513. 
to completely discredit and discountenance both the McIntosh party and the commissioners they hoped to set a precedent for a high standard of political integrity, for the Cherokees who, in times past, had been known to show too much susceptibility to bribery. At the same time they hoped to discourage any further attempts on the part of the United States to secure cessions of land from them. Prompt action was taken that very evening. Ridge and McCoy had a confidential talk with the unsuspecting McIntosh to ascertain whether the course he had proposed was with the knowledge and sanction of the commissioners. They found that it was with their knowledge and sanction. After suggesting that the Cherokees, Creeks, Choctaws and Chickasaws should surrender all of their lands east of the Mississippi and settle in the west under one government, McIntosh proposed that he himself attend a joint session of the two houses and address them in favor of compliance with the propositions of the commissioners. He then added that he was certain that if the Committee would fall in with his views and say that they despaired of being able to hold out against the United States the old Path Killer could readily be brought to yield. He concluded by trying to dazzle them with an account of all he had gained by former treaties both for himself and others, "all knowledge of which was buried in oblivion". ${ }^{17}$

The Committee in secret session early next morning resolved to convene both houses in General Council that day on "special and important business" and an invitation was sent General McIntosh to attend. He was received with the usual respect and deference, yet seemed ill at ease. The air of expectancy and suppressed excitement which prevailed the council chamber seemed to warn him that all was not well. The meeting having been opened by Major Ridge, speaker of the Council, Mr. Ross arose to explain its purpose. He began by reviewing his own past services and obligations to the Cherokees, expressing his appreciation of the trust and confidence with which his people had honored him. He assured them their trust and confidence had been sacredly observed for he considered a traitor more despicable than the meanest reptile that crawls upon

${ }^{17}$ Ibid 
the earth; as for himself, he would rather live in the direst poverty than to have his reputation sullied by the acceptance of a bribe. "It has now become my duty," he concluded, "to inform you that a gross contempt is offered my character as well as that of the General Council. This letter which I hold in my hand will speak for itself. Fortunately the author has mistaken my character and sense of honor." Handing the letter to the clerk of the Council, he took his seat.

Over the council house there fell an ominous silence which was presently broken by the voice of the clerk who, sentence by sentence, read the note aloud, and interpreted it in Cherokee in order that everyone present might understand it. When it was finished, the venerable Path Killer, tall, erect, and dignified, his flashing eye alone revealing his deep emotion, arose to express his grief and astonishment, that one whom he had trusted as an honest chief, and loved and confided in as a brother had been willing to betray his brothers, the Cherokees, for a handful of gold. The offense could not be condoned. All affection must expire before such a breach of trust, and the Couneil should deal with him as the traitor he had proved himself to be.

By the time the aged chief had finished, the full significance of the situation had dawned upon the discredited chief and the outraged Council. The former rose to stammer out a lame reply, but his voice was drowned by angry accusations and harsh epithets. The Council, forthwith, proceeded to pass a resolution deposing McIntosh and debarring him from ever having any part in the Cherokee councils. Taking advantage of the excitement aroused by the dramatic incidents of the morning, the discredited chief escaped from the council house, mounted his horse and rode in hot haste from the scene of his disgrace. $^{18}$

A communication from the Cherokee Council to the Creek Nation the following day simply states, "The commissioners have this day departed without a foot of land, and we wish you prosperity in all your national concerns". ${ }^{19} \mathrm{Mr}$. Campbell re-

${ }^{18} \mathrm{~A}$ full account of the McIntosh affair is given in Payne Mss. 2, pp. 509-520.

${ }^{10}$ Payne Mss. 7, p. 61. 
ported to the War Office the failure of the commissioners to consummate a treaty, merely mentioning the fact that a delegation of Creeks headed by General McIntosh had visited them. $\mathrm{He}$ added that the prospect of securing a cession from the Creeks was more favorable, but made no mention of the McIntosh incident. ${ }^{20}$

Although the Cherokees had stood by their determination to part with no more land the incidents of the past few weeks had aroused among them such feelings of uncertainty and uneasiness that the Council, before adjourning, appointed a delegation to Washington to plead with the President personally against further requests for land cessions.

${ }^{20}$ American State Papers, Indian Affairs, II, p. 464. 


\section{CHAPTER V}

\section{Georgia's Hostility to the Cherokees}

The Cherokee delegation, composed of John Ross, Major Ridge, George Lowrey and Elijah Hicks, set out to Washington promptly on the adjournment of Council. They travelled on horseback carrying whatever was necessary to the journey in saddlebags strapped behind their saddles. The trip up to the capital at this time of year was not an easy one. But as they rode two and two over wind-swept ridges and through snowcovered valleys, or, at night, sat by the fire of the wayside "public stop", they never tired of discussing the questions of the day, particularly those which concerned the welfare of their own nation. For several years they had been associated together in the Cherokee Council, knew each other well, and trusted each other implicitly. They were all men of affairs also, and although one of them could not read or write in English, he had acquired much useful information and was keen and astute in managing the political affairs of his people. ${ }^{1}$ Ross was doubtless the best educated one of the four. Besides his two years' experience in the Academy at Maryville he had read many valuable books which he found in his father's library and his letters prove that he wrote very clearly, though his style was somewhat formal and stilted. As to personal appearance, they all possessed the independent, dignified bearing which has always distinguished Cherokee men reared in the mountains, and their natural politeness and courtesy marked them as gentlemen, in spite of the fact that their forbears, a generation or two before, had been considered savages. The selection of these men to represent their nation in its plea to the Great White Father at Washington undoubtedly shows discrimination and judgment on the part of the tribe.

Arriving in Washington the middle of January the delegation learned, to their disappointment, that they could not confer personally with the President but that any business which they wished to transact with the executive must pass through

${ }^{1}$ Major Ridge. 
the War Office. When they presented their credentials to Secretary Calhoun he sounded the keynote of the Federal policy by asking them if they had come to make a further cession of land. Their answer was in the form of a memorial in which they earnestly urged that their nation was laboring under peculiar disadvantages arising from the repeated appropriations of Congress to hold treaties with them; such action retarded national improvement by unsettling the minds and prospects of the citizens. They repeated their determination to part with no more land, as the limits fixed by the treaty of 1819 left them territory barely adequate to their comfort and convenience; the Cherokees were rapidly increasing in population, rendering it the duty of the nation to preserve, unimpaired to posterity, the lands of their ancestors. For these reasons, they asked that some other arrangement be made whereby Georgia's demand for land might be satisfied. ${ }^{2}$

The Secretary of War, in reply, laid great stress upon the Georgia compact and upon the zealous desire of the President to carry it out, a distinct society or nation within the limits of a state being "incompatible with our system". ${ }^{3}$ He then set forth in glowing terms the benefits that would result to the Cherokees from an exchange of their country for one beyond the annoying encroachments of civilization. The delegation reminded him that the United States was under compact to extinguish the Indian claims only on peaceable and reasonable terms; as for incompatibility with the system of the United States, the Indians were the original inhabitants of the country, and were not willing to allow the sovereignty of any state within the boundaries of their domain; they had never promised to cede their lands to the Federal Government, but it had guaranteed the land to them; they were not yet sufficiently civilized to cease being an independent community and become a territory or state within the Union; removal would at least retard their advancement in civilization since it would take them some time to adjust themselves to new environments. ${ }^{4}$ The Indians

${ }^{2}$ American State Papers, Indian Affairs, II, p. 473; Cong. Doc. 91, No. 63.

- Third Cong. Doc. 91, Sen. Doc. 63.

- American State Papers, Indian Affairs, II, p. 474. 
had justice and logic on their side and argued their case so cogently that even the astute Secretary of War was unable to refute them. At the suggestion of the President copies of the correspondence were sent to the Georgia delegation in Congress and to George M. Troup, Governor of the state. Troup was an extreme state's rights man who represented the rich planter population. He had been elected governor of Georgia with the avowed policy of ridding the state of Indian occupancy.

The Georgia congressmen protested against the diplomatic courtesy shown the Indian delegates, and complained that the civilizing policy of the United States tended to fasten the Indians more firmly on the soil. ${ }^{5}$ The hot-headed governor, after censuring the weak and dilatory policy of the Federal Government towards the Indians in the past, and accusing the white men in the Cherokee Nation of influencing them against removal, declared that the fee simple of the lands lay in Georgia and that the Indians were tenants at her will; Georgia demanded the removal of these tenants who must be given to understand that the United States, at the expense of bloodshed, must assist Georgia to occupy her lands.

President Monroe, in his message March, 1824, defended the course which the national executive had pursued towards the Indians. He advocated removal beyond the Mississippi but not by force, and expressed the opinion that the Indian title was not affected by the Georgia compact, the expression, "at the expense of the United States as long as the same can be done on reasonable terms", being full proof of the distinct understanding of both parties to the compact. The Indians had a right, he thought, to the territory in the disposal of which they were to be considered as free agents. ${ }^{6}$

A select committee from the House of Representatives, of which John Forsythe was chairman, reported on this message April 15, after expressing the opinion that the guarantee of lands before 1802 granted occupancy title only, and resolved that if peaceable acquisition were not now possible the Indians must be removed by force or the United States obtain from

'Niles' Register 26, 275. Hardin's Life of George M. Troup, 206-218.

' Richardson's Messages of the Presidents, II, pp. 234-237. 
Georgia consent to some other plan; otherwise she might be put in the position of either seeing the Cherokees annihilated or defending them against United States citizens. ${ }^{7}$

Governor Troup was provoked to a fresh outburst of wrath by the President's message and by the discussions in Congress, but when a fresh appropriation was made the last of May to extinguish Indian land titles in Georgia ${ }^{8}$ he quieted down for a time, confining his views on state's rights and the Indian question to the state legislature. Here, however, he hotly declared that "a state of things so unnatural and fruitful of evil as an independent government of a semibarbarous people existing within the limits of a state could not long continue, and wise counsel must direct it, that relations which could not be maintained in peace should be dissolved before an occasion should

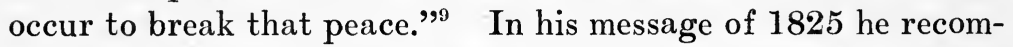
mended the legislature to adopt energetic measures for ridding the Cherokee Nation of all white people excepting only such as were necessarily employed by the United States to regulate commerce with the tribe. He also recommended the legislature to extend the laws of Georgia over the Cherokee Nation. ${ }^{10}$ The Cherokees, however, held fast to their contention for national rights and when Georgia attempted to send surveyors through their nation to lay out the course of a canal the Council refused to permit it. "No individual state shall be allowed to make internal improvements within the sovereign limits of the Cherokee Nation", was resolved by the Council of $1826 .{ }^{11}$ This exasperated Governor Troup, who, however, was forced to bide his time, his attention, at this time being more particularly directed towards the removal of the Creeks and Seminoles.

Thus far, it would seem the Cherokees had gained the best of the controversy. With firmness and determination they had maintained their right to the soil and the sovereignty of their

'Niles' Register 26, 275-276.

${ }^{8} 4$ United States Statutes at Large, p. 36.

- Hardin's Life of George M. Troup, p. 469.

${ }^{10}$ Ibid, pp. 411, 412.

${ }^{11}$ Payne Mss. 7. 
nation; the delegation at Washington had won many friends for their cause in Congress. But the Cherokees did not permit themselves to be betrayed by overconfidence in the security of their position. They were keenly conscious that the ability to maintain their position depended upon their own alertness and resourcefulness. To the national ambition for advancement was now added a more powerful incentive, that of self-preservation. 


\section{CHAPTER VI}

\section{The Cherokees Adopt a Constitution}

Georgia had charged, as one of her arguments for removal, that the Cherokees were a semibarbarous people who stood in the way of state progress. As a matter of fact, they were almost as progressive as the white people of the state at that time. ${ }^{1}$ According to a report made to the War Department by the Reverend David Brown, ${ }^{2}$ who travelled extensively through the Cherokee Nation in the fall of 1825, farming and stock raising were successfully carried on, apple and peach orchards were common, and much attention was paid to the cultivation of gardens. Corn, wheat, oats, and tobacco were raised in abundance and cotton in sufficient quantities to supply their own use and leave a considerable surplus to be shipped in boats of their own make to New Orleans. Hides and live stock sold to the neighboring states brought sufficient currency into the nation. ${ }^{3}$ There were many flourishing villages and the numerous roads through the country had "public stops" kept by natives at convenient intervals. In the homes, cotton and woolen cloth and blankets and coverlets were woven, and stockings and gloves knitted. There were blacksmiths, silversmiths and now and then a native carpenter. ${ }^{4}$ Commercial enterprises were being extended, and nearly all the merchants were Cherokee citizens. Churches and schools were increasing and plans were discussed for a high school, a library and a museum to be established and maintained at the expense of the Cherokee Nation. In one district alone there were reported to be upwards of a thousand volumes of good books, while eleven periodicals, political and religious were taken and

${ }^{1}$ Payne Mss. 2.

${ }^{2}$ Cong. Doc. 138, No. 124; McKenney's Report of 1826; Amer. State Papers, II, p. 651 .

${ }^{8}$ In 1826 there were 22,000 cattle, 7,000 horses, 46,000 swine and 25,000 sheep. Niles 30 , p. 145 .

- Of saw mills there were sixteen, grist mills, thirty-one, looms, seven hundred and sixty-two, cotton mills, eight, and ferries, eighteen. Ibid. 
read. It is doubtful whether in the surrounding country many groups of white population of equal number could have shown a better record. Stringent laws were passed against drunkenness and the introduction of intoxicating liquors into the nation and indolence was frowned upon. The government was well organized and administered, while the revenue was in a flourishing condition. ${ }^{5}$

Adherence to some of their primitive customs in government had given rise to the accusation that they were uncivilized. In order to disabuse the mind of Georgia and the whole world of this idea, and to establish a firmer political foundation on which to build a greater Cherokee Nation, the Cherokees determined to establish a regular republican form of government based on a written constitution. ${ }^{6}$ The idea is said to have originated with John Ross; it is probably more nearly the truth to say that the plan was wrought out by the four men who went up to Washington in the winter of 1824. Be that as it may a resolution passed by the General Council in the fall of 1826 provided for a constitutional convention to meet July 4, the following year at New Echota. On July 1 delegates to the convention were elected from each of the eight districts into which the nation had been divided in 1820 . Voting was conducted viva voce. In some districts interest was so great that the election "was warm and closely contested"? The convention met and organized by electing John Ross chairman. It then promptly addressed itself to the business of drafting a constitution. This document is closely modeled after the constitution of the United States and differs from it merely to meet the needs of local conditions. The most striking departure is found in the words of the preamble, "We, the Cherokee people, constituting one of the sovereign and independent nations of the earth and having complete jurisdiction over its territory to the exclusion of the authority of any other state, do ordain this constitution". 8 The executive branch of the

'American State Papers, Indian Affairs, II, 651, 652.

- Cherokee Phoenix, February, 1828.

' Niles' Register 32, 255.

${ }^{8}$ Cony. Doc. 273, No. 91; Payne Mss. 2. 
government was to be composed of a principal and a second chief, the legislature to consist of a National Committee composed of two representatives from each district and a Council composed of three, both branches to be styled "The General Council of the Cherokee Nation". The judiciary followed closely that outlined by the constitution of the United States. White men married into the tribe were to enjoy all the privileges of citizenship except the right to hold office, and land was still to remain the common property of the nation, improvements only belonging exclusively and indefeasibly to the individual citizen. It provided religious toleration but no minister of the gospel was eligible to the office of Principal Chief or to a seat in the General Council. ${ }^{9}$ All the provisions for a well regulated government were laid down in much detail and an Alabama paper commenting upon it thought the document taken as a whole well "calculated to produce the most happy results. The success of the Cherokees will stimulate other nations to adopt a similar policy; and we may yet live to see one take after another, by dropping the tomahawk and following the example set them rise from savage barbarity to respectability in the civilized world". ${ }^{10}$ Three weeks later this constitution had been submitted to the people and ratified. When it went into effect the following year a new era in the history of the Cherokees had begun. ${ }^{11}$

Meanwhile the aged Path Killer, leader of the Conservative party, died ${ }^{12}$ and was followed in office by the second chief, Charles R. Hicks, who outlived him less than two weeks. The government then devolved upon Major Ridge, speaker of the Council, and John Ross, president of the Committee, until the regular meeting of Council the following fall.

Major Ridge, at this time one of the most prominent men of the tribe, was a full-blood Cherokee and was undoubtedly one of the most able men the Cherokee Nation has ever produced. Handsome and commanding in appearance, keen and alert in

\footnotetext{
'Cherokee Phoenix, Feb. 28, 1828.

${ }^{10}$ Huntsville Democrat, in Niles' Register 33, 214.

${ }^{11}$ Niles' Register 32, p. 214.

12 Jan. 8, 1827.
} 
intellect, broad-minded and public-spirited, possessed of great strength of character and personal magnetism, he was a natural leader of men. By the sheer force of his native ability he forged his way to the front of Cherokee national affairs, where for more than thirty years he exercised a strong influence over the policy of the government. Like Sequoyah he had had no school advantages and was unable to read or write in English. His signature in the public records is made with a cross. Realizing the advantages of education from his own lack of it he encouraged schools in the nation and sent his son, John Ridge, to be educated at Cornwall, Connecticut. In speaking of the work of the missionaries he once said that he could never be thankful enough to them for providing a way for his son to receive an education. He wished him to stay at Cornwall until he got a "great education"; he hoped, also, that the Lord would give him "a good heart" so that when he came home he might be very useful to the nation. ${ }^{13}$ Since 1809 , when at the suggestion of Agent Meigs a delegation had been appointed to go to Washington to treat for an exchange of lands, he had stood firmly and consistently opposed to removal. He was at this time a poor, unknown youth and this was his first attendance at Council. Nevertheless, he arose in the presence of the assembled chiefs, an unprecedented thing for a young man to do without invitation, and delivered such a fiery and eloquent appeal to the patriotism of the Indians that the project was promptly abandoned. ${ }^{14}$ For John Ross, who was several years his junior, he cherished a strong admiration and attachment and the younger man owed much of his rapid political advancement to Major Ridge.

To fill the unexpired term of Path Killer and Charles $\mathbf{R}$. Hicks, the Council, at regular session in the fall of 1827, appointed William Hicks ${ }^{15}$ as principal, and John Ross as second chief. Naturally Hicks was fired with the ambition to become chief magistrate of the new government which went into effect

${ }^{18}$ Morse, Indian Reports, p. 162.

${ }^{14}$ McKenny and Hall, Indian Tribes of North America, I, p. 189 (1879); Vol. II, pp. 77-106 (1885).

${ }^{15}$ This is said to have been done out of respect for his brother, Charles Ri Hicks, who was ior many years the most influential chief of the tribe and was greatly beloved by his tribesmen. 
under the constitution in the following fall, and for a time his prospects seemed fair enough. But as the weeks went by he was frequently seen in company with United States agents and Georgia citizens. This aroused the suspicion of the Cherokees. A rumor went abroad that he was being tampered with and that he favored emigration and the sale of the country. This presaged his certain defeat and his friends tried to save him humiliation by persuading him to withdraw from the lists. He would not listen to them and was overwhelmingly defeated by John Ross, the opposition candidate placed in the field just before the election. This check to Hick's ambition so embittered him that he never recovered from his disappointment. Every effort was made to win him back to himself and to his allegiance to his country, but the himiliation seemed to prey upon his mind and spirits. Such a man was not to be overlooked by designing white men seeking an entering wedge to split the nation into factions. ${ }^{16}$

Ross was now the most prominent man of his tribe both in the Cherokee Nation and out of it. His quiet, pleasant address, his integrity and sincerity of character together with his remarkable powers of self-control and discretion, which made him beloved by the Cherokees, won for him also the confidence and affection of the missionaries and the respect of statesmen and philanthropists in the north as well as of Federal officials with whom he had to deal in the Cherokee Nation. He was a prosperous merchant and planter and lived in the style befitting his position. His wife, a full-blood Cherokee, known by her Indian name of Quata, was a woman of much intelligence and native ability, possessing race prejudice and considerable influence with the tribe. From Ross's Landing he had moved to the head of the Coosa River ${ }^{17}$ where he had built a commodious twostory house and furnished it with some degree of luxury and refined taste. Here he had for neighbors Major Ridge who lived two miles away on the Coosa in a substantial and comfortable home. John Ridge, whose Connecticut bride had insisted upon casting her lot with her husband's people, had built

${ }^{16}$ Payne Mss. 2, p. 273.

${ }^{17}$ Now Rome, Georgia. 
a home not far distant on the Two Run a few miles east of Oostinahleh. Elias Boudinot, cousin of John Ridge, also educated in Connecticut and the first editor of the Cherokee Phoenix, lived at New Echota. ${ }^{18}$ The treasurer of the Cherokee Nation, Major Jack Martin, had a handsome residence with carved mantels and marble hearths at Rock Springs. It is still standing. ${ }^{19}$ James Vann had built a two-story brick mansion at Vann's Spring Place. These were some of Ross's friends among the wealthy and progressive men of the tribe.

As a delegate to Washington a good many winters Mr. Ross had come in contact with some of the greatest statesmen and politicians of his time. He was a close and keen observer of men and things and possessed, to a remarkable degree, the power of interpreting what he saw and heard and adapting it to his own and his nation's need. At the national capital he had gained much knowledge and inspiration which he was eager to put into practice for the benefit of the people of his tribe. The United States had practically recognized the Cherokce $\mathrm{Na-}$ tion as an independent nation; the Cherokee delegates had been accorded diplomatic courtesy in Washington; the tribe had an alphabet, a printing press, a newspaper and a written constitution; industry and prosperity were in evidence throughout the length and breadth of their domain. Patriotism was at the full tide. Is it any wonder that the young Scotch Cherokee chief, fired with patriotic ardor and ambition, should begin to dream dreams and see visions of a greater Cherokee Nation, a republic of civilized Indians that should be the wonder and admiration of the world? Whether he could have made his dreams come true had he been left to work out the plan unmolested will never be known.

Georgia thought it was high time she was taking a hand when an independent republic was being set up with the intent to perpetuate a distinct community within her ancient and chartered limits. The legislature, December $2 \%$, passed a resolution reasserting that the title of the Cherokees to the land was temporary and that they were tenants at the will of the

${ }^{18} \mathrm{His}$ wife was a New England woman, also.

${ }^{19}$ Gude, Georgia and the Cherokees, p. 33. It is known as the home of Colonel Carter's family. 
state which was now at full liberty to possess herself, by any means which she might choose, of the lands in dispute and extend over them her authority and laws. Georgia would give the Federal government one more chance to rid the state of Indians. If this failed the next legislature was urged to extend the jurisdiction and laws of the state over their territory. ${ }^{20}$ Governor Forsythe sent a copy of these resolutions to the President and included one of the "presumptuous" constitutions just adopted by the Cherokee Nation asking what he proposed to do about the erection of an independent government within the limits of the state. ${ }^{21}$ In March the House of Representatives took up the question and instructed the judiciary committee ${ }^{22}$ and later the Indian committee ${ }^{23}$ to inquire into the circumstances of the new Cherokee republic and report upon the expediency of arresting its designs.

But since the War Department was negotiating a treaty with the Arkansas Cherokees whereby their territorial limits were readjusted and their boundary lines permanently settled ${ }^{24}$ it was hoped that sufficient inducement might be held out to the Eastern Cherokees to emigrate. The Indian appropriation bill contained a specific grant for $\$ 50,000$ for carrying into effect the compact of $1802 .^{25}$ This appropriation stimulated the Federal Government to renewed effort and Colonel Montgomery, the Indian agent, was given orders to provide transportation, rifles and blankets for such Cherokees as were ready to go west. Confidential agents were sent into the Cherokee Nation to induce cession or emigration. Captain James Rogers was employed at a salary of $\$ 500$ down and $\$ 500$ more if he succeeded to go among the Cherokees and "explain to them the kind of soil, the climates, and prospects that awaited them in the west, and to use in his discretion the best methods to induce the Indians ${ }^{23}$ to emigrate. Captain Rogers was a half-blood

${ }^{20}$ Acts of Georgia Assembly, 1827, p. 249.

${ }^{21}$ Niles' Register 33, p. 406.

${ }^{22}$ Gales and Seaton's Register Vol. IV, Part I, p. 914.

${ }^{23}$ Ibid, p. 925.

${ }_{24} 7$ U. S. Statutes at Large, p. 311, May 6, 1828.

${ }^{25} 4$ U. S. Statutes at Large, p. 300, May 9, 1828.

${ }^{28}$ Indian Office Letter Books, Series II, No. 5, p. 33, May 2\%, 1828; McKenney to Moymer; Abel, Indian Consolidation, p. 361. 
Cherokee of considerable intelligence. For various reasons his mission proved an expensive failure.

When the Cherokee Council met in October, 1828, it immediately took up the contentions of Georgia and answered them so ably that any sentiment for removal which might have existed among the members of the tribe was neutralized. ${ }^{27}$ Colonel Montgomery, was ordered to leave his office in charge of a subagent and go out among the Indians to persuade them to enroll for emigration. He reported such strong and bitter opposition however, both towards the agents and towards the Indians who were enrolling ${ }^{28}$ that those who knew the situation in the Cherokee Nation most intimately were now convinced that the policy of voluntary removal advocated and ably defended by President Monroe and taken over by President Adams was a lost issue. Removal, if accomplished at all, must be accomplished by coercion. In the presidential election of 1828 the south and the west rallied to the support of a presidential candidate from whom they had every reason to expect a change of tactics if he should come into power as the chief executive of the nation.

${ }^{27}$ Niles' Register 35.

${ }^{28}$ Cong. Doc. 186, No. 95. 


\section{CHAPTER VII}

\section{The Removal Bill}

In October, 1828, Ross entered upon his duties as chief executive of the Cherokee republic. Although engrossed with the business of organizing the government and readjusting the old order of things to suit the new conditions, he followed with keen interest the absorbing question of the day, the presidential election, which held such portentous possibilities for the Cherokee Nation ${ }^{1}$. Georgia realized these possibilities, and scarcely a month had elapsed after the result of the election was known when her legislature passed two acts intended to paralyse the Cherokee government. The first added Cherokee lands to certain northwestern counties of Georgia; the second extended the laws of the state over these lands after January $1,1830,{ }^{2}$ the Cherokee laws and customs to be null thereafter.

The Cherokees, aglow with patriotic pride and ambition, had no intention of submitting to such humiliation. The General Council, in session at New Echota, determined to appeal to the President of the United States for protection against the State. $^{3}$ It passed a resolution declaring the Georgia laws null and void and framed a memorial to the national executive protesting against that state's legislation, contrasting it with her profession of belief in the liberty and rights of man. The memorial recalled the guarantee of the United States to the Cherokees; pleaded that the Cherokees, an innocent party not responsible for the compact with Georgia, were compelled to suffer for it; called attention to the advancement of the people due largely to their proximity to civilizing influence, insisted that benefits to be gained by. removal were purely visionary and asked the President to protect them in their treaty rights. ${ }^{4}$

The delegation bearing the memorial arrived at the capital in the winter of 1829 to find themselves unable to get any

${ }^{1}$ Cherokee Phoenix, August, September and October, 1828.

${ }^{2}$ Dawson, Compilation of the Laves of the State of Georgia, 1829, 29-198.

${ }^{3}$ Cherokee Phoenix, October, 1828.

'Cong. Doc. 187, No. 145; Parker, The Cherokee Indians, p. 19. 
satisfaction from the retiring administration. Hoping against hope for greater success in dealing with an executive who proclaimed justice his cardinal doctrine they determined to wait and present their cause to President Jackson. They attended the inaugural ceremonies and doubtless it filled them with renewed hope to hear him say on that occasion that it would be his sincere and constant desire to observe towards the Indians a just and liberal policy, and to give that humane and considerate attention to their rights and their wants which was "consistent with the habits of our government and the feelings of the people." The last clause they were not yet prepared to interpret and appreciate. The Georgia contingent in Congress understood it better.

More than a month wore away before the delegation finally secured a hearing with the Secretary of War. Any hopes which the President's message had aroused were dispelled by Major Eaton when, on April 18, he assured them that no remedy remained for their troubles but removal. If they wanted a home they could call their own they must go west, for there the President could guarantee the soil to them "as long as trees grow and waters run." 'The Cherokees contended that their people had been happy and prosperous in the land of their fathers and that removal would bring retrogression and disaster upon the tribe; they did not want to move. The executive mind was made up just as firmly, however, and in May the delegation returned home to report the result of their mission. ${ }^{7}$ Before leaving Washington, they had been encouraged by statesmen of the north and east to believe that Congress at its next session would come to their relief. An extra session of Council, called to hear the report of the delegation, there-

${ }^{5}$ Richardson's Messages of the Presidents, II, p. 438.

${ }^{6}$ Natchez Statesman and Gazette, June 29, 1829, Niles' Register 36 , p. 258; Payne Mss. 2. "If you will go to the setting sun there you will be happy; there you can remain in peace and quietness; so long as the waters run and the oaks grow that country shall be guaranteed to you and no white man shall be permitted to settle near you." Payne Mss. 6.

${ }^{7}$ Cherokee Phoenix, May, 1828. 
fore, drew up memorials to the national legislature, praying for relief and potection on the ground of treaty obligations.

But Congress did not meet for several months. Meanwhile to help along the removal project the President determined to send a secret agent among the Cherokees and the Creeks to see what could be done in the way of securing individual acquiescence with the view, as later events proved, to building up a party favorable to removal with which a treaty could be negotiated. He selected for this delicate mission General William Carroll, then a candidate for governor of Tennessee and a man supposed to have considerable influence with the Indians. His instructions to conceal from even the chiefs the official character he carried with him, and the suggestion that presents to the amount of not more than $\$ 2000$ be distributed to the poorer Indians, the chiefs' children and even the chiefs themselves with the object of attaching them to him, ${ }^{8}$ indicate the trend of the administration in dealing with the Indians. General Carroll went to the Cherokee Nation, saw the conditions there and reported to the War Department on November 19 that the Cherokees were too intelligent and "too well posted on current news of the day" to be kept in ignorance of the motives and methods of those who came among them. He paid a high tribute to Cherokee civilization and expressed the opinion that they were encouraged by eastern newspapers to believe that the people did not support the President in his views on removal, and that Congress, at the next session, would sustain them in their protests against the encroachments of Georgia. ${ }^{9}$

That was enough for President Jackson. Determined to forestall the Cherokees and their friends he sent a message to Congress December 8, in which he advocated Indian removal on the ground that the rights of a sovereign state were being interfered with, and stated in reply to the protest of the Cherokees against the extension of Georgia laws over them, that the attempt of the Indians to establish an independent government in Georgia and Alabama would not be countenanced. ${ }^{10}$

${ }^{8}$ Eaton's Letters of Instruction to Carroll, May 30, 1829. Indian Office Manuscript Records.

'Ibid. Carroll to Eaton. November 19, 1829.

${ }^{10}$ Richardson's Messages of the Presidents, II, 456-459. 
Both the House and the Senate promptly took up the question and all through the winter the Removal Bill brought out much bitter feeling and some memorable discussions in defense of the Indians. In the Senate it was the main topic of discussion in the committee of the whole for three weeks. Frelinghuysen of New Jersey and Sprague of Maine ably opposed it on the ground of the binding force of treaty obligations, and upon general principles of justice and humanity. Forsythe of Georgia, McKinley of Alabama and White of Tennessee, appealing to sectional prejudice, defended it on the theory of the state's right to the soil within its limits. In the House the fallacy of pretending to remove the Indians for their own good from a community where they had comfortable homes, cultivated fields, churches and schools, to a wilderness where they would be surrounded by savage tribes, was exposed by Storrs of New York in a speech remarkable for its logic and forensic power. He attacked the President for arrogating to himself authority never conferred upon him in presuming to deliver to Congress an opinion on state authority and for seeking to annul treaties, some of which he himself had negotiated. ${ }^{11}$

As the discussions in the national legislature revealed the situation of the Indians the indignation of the country at large was aroused and protests poured in upon Congress. One from Adams County, Pennsylvania, praying for the protection of the Indians is particularly worthy of notice. It declared that the Cherokees were an independent nation entitled to all the right of such except so far as surrendered by treaty. The treaties of Hopewell and Holston had taken place before the compact with Georgia was entered into. In this compact Georgia had explicity acknowledged the existence of the Indians as a nation with whom the United States were to hold treaties and extinguish their title as soon as the same could be done on peaceable and reasonable terms, and by such acknowledgment admitted the validity of former treaties which guaranteed their existence and protection. The treaty of Hopewell was older than the constitution. The constitution in declaring treaties the

${ }^{11}$ Gales and Seaton's Register, Vol. VI, Part II, pp. 996-1003. Index to Senate and House Journals, 21st Congress, 1st session; National Intelligencer, May 24, 1838. 
supreme law of the land directly recognized the right to treat with Indians and treaties regularly negotiated with them were sacred as any law of the land. ${ }^{12}$

In spite of protests and hot debate the Removal Bill passed in May, ${ }^{13}$ and was promptly signed by the President. It was, in the words of Senator Benton, "one of the closest and most earnestly contested questions of the session and was carried by an inconsiderable majority." "14

A new complication was added to the Cherokee troubles in July 1829 when deposits of gold, found on Ward's Creek in the northwestern part of the nation, caused the value of Cherokee land to increase enormously. Treasure seekers from the surrounding states flocked into the gold region in such numbers that within a year three thousand disorderly white men were prospecting for the precious ore on Cherokee soil. They found the business very profitable. Early in October, 1830, the New York American reported that two hundred and thirty thousand dollars worth of gold had been received in Augusta, alone, during the last nine months; and Mr. Templeton Reid was coining and stamping, at his mint in Gainesville, Georgia, a hundred dollars of gold every day. ${ }^{15}$ These gold diggers were intruders operating unlawfully under an enactment of the Cherokee Nation prohibiting anyone to settle or trade on their land without a permit from Cherokee officials, and under a Federal intercourse law prohibiting nyone frm settling or trading on Indian territory without a special license from the proper United States authorities. ${ }^{16}$ The gold diggers paid no attention to either the Cherokee or Federal laws. A period of lawlessness prevailed in which the Cherokees who had joined eagerly in prospecting got the worst of the bargain. Governor Gilmer, always with an eye single to the interests of his state, issued a proclamation in which he warned all persons, even Indian occupants, from trespassing upon Georgia soil, and es-

${ }^{12}$ Cong. Doc. 208, No. 90.

${ }^{13} 4$ U. S. Statutes at Large, p. 411.

${ }^{14}$ Benton's Thirty Years' View, I, 164.

${ }^{15}$ Niles' Register 39, p. 106.

${ }^{10}$ Georgia had declared her laws would go into effect there June 1, 1830. 
pecially from taking any gold or silver from the land. ${ }^{17}$ The Indians, considering that they had a right to do what they would with their own, paid no attention to the proclamation. Thereupon the Georgia authorities arrested and roughly marched them off to prison. The United States troops, sent into the country in 1829 to quell the tumult, when appealed to, refused to give the Indians any protection on the ground that state laws were not to be interfered with. ${ }^{18}$

When the Georgia legislature convened in October it immediately proceeded to pass laws for the gold region. ${ }^{19}$ October 29, the governor wrote to the President asking that the troops be removed since Georgia had extended her jurisdiction over that region. This request was granted and the troops went into winter quarters leaving the state a free hand. ${ }^{20}$ The legislature next proceeded to establish a guard of sixty men stationed at the agency to keep down disorders in the gold region; it then passed an act making it unlawful for the Cherokee Council to meet except for the purpose of ceding land, while a penalty of four years' imprisonment was fixed for Cherokee judges who presumed to hold court. The same law provided that all white persons residing in the Cherokee country on March 1, 1831, or thereafter, without a license from the governor of Georgia should be guilty of misdemeanor, the penalty being not less than four years' imprisonment; the governor was allowed to license those who would take an oath to support and defend the constitution and laws of Georgia and to demean themselves uprightly as citizens of the State. ${ }^{22}$

Further legislation followed in the next few years providing for the mapping out of the Cherokee territory into counties and for surveying it into land lots of 160 acres each and gold lots of forty acres each. These lots were put up and distributed among white citizens of Georgia, each receiving a ticket. While

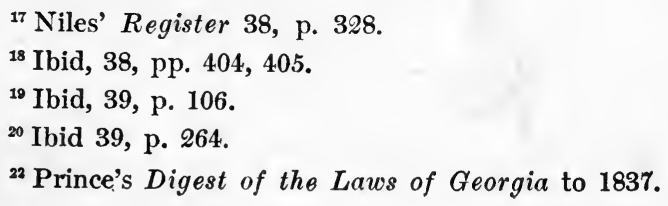


each Cherokee was allowed a reservation of 160 acres no deed was given and possession of it depended upon the pleasure of the state legislature. Contests over these lottery claims were inevitable. Provision was made for those arising among white people. A law forbidding anyone of Indian blood to bring suit or testify against a white man made it impossible for the Indian to defend his rights in any court or to resist the seizure of his homestead or even his dwelling house under penalty of imprisonment at the discretion of the Georgia courts. Another law making invalid any contract made by an Indian unless established by the testimony of two white men practically cancelled all debts due from white men to Indians. The purpose of these laws was not far to seek. Georgia was "building fires around the Cherokees" to force them to remove. White men who entered the Cherokee country in armed bands, called "Poney-clubs," ${ }^{23}$ seized horses and cattle and drove them off, ejected families from their homes and set fire to their houses, turning the occupants out in bleak weather to seek shelter where they might. These were but some of the atrocities perpetrated by the Georgians. When the perpetrators were arrested and brought to trial, the cases were dismissed on the ground that no Indian could testify against a white man. ${ }^{24}$

The conscience of the whole country was aroused as the situation of the Indians became known. Criticism of national Executive and Legislature became too uncomfortable for the President. He had intended that removal should be accomplished with less notoriety. Therefore in order further to disable them and prevent them from employing attorneys, sending delegates to Washington and publishing the Cherokee Phoenix, Jackson issued instructions through the War Department to Indian agents in 1830 that henceforth annuities were to be distributed among families and individuals. ${ }^{25}$ The annuity was a sum of money paid annually by the United States to the Cherokees in consideration for land cessions made at various times after the treaty of Hopewell. It amounted at this time to $\$ 10,000$, two-

${ }^{23}$ Niles' Register 40, p. 132.

${ }^{24}$ Edward Everett, Speech in Senate, April 16, 1830. Peter Force, Printer. Niles' Register 39, pp. 179-180.

${ }^{25}$ Cong. Doc. 208, No. 102, p. 2. 
thirds of which was due to the eastern nation. Since 1819 it had been turned over to a national treasurer elected by the tribe and used for the support of the government and for other national expenses. As a per capita payment it amounted to about forty-two cents, a sum less than the expense of a trip to the agency to "draw" it. The Cherokees refused to receive it in this fashion and, although they voted time after time that it should be paid in the usual way to their treasurer, it was withheld and allowed to accumulate in a Nashville ${ }^{26}$ bank for five years while the Council was forced to raise loans on the credit of the nation and to issue duebills for the payment of salaries. ${ }^{27}$ The United States commissioners used the annuities as a pretext for assembling the tribe for the purpose of urging removal, much to their inconvenience and annoyance.

But neither the withholding of annuities nor the encroachment upon their territory by state authority facilitated the object aimed at by Georgia. The Cherokees, conscious of their rights and of the support of public opinion, refused to remove or even to treat for a small cession of land.

When it became evident that the object of Georgia's hostile legislation, the Removal Bill and the President's suspension of annuities, all looked toward forcible removal, Chief Ross, acting on the suggestion of such men as Webster and Frelinghuysen determined to appeal for redress to the Supreme Court. He employed ex-Attorney General Wirt and Mr. Sargeant as counsel, who, in January, 1831, introduced a motion before the Supreme Court for an injunction to prevent the execution of the objectionable laws of Georgia.

This motion was reached on the docket of the Supreme Court early in March. ${ }^{28}$ The bill set forth the complainant to be the Cherokee Nation of Indians, a foreign state, not owing allegiance to the United States, nor to any state of the Union, nor to any prince, potentate or any state other than their own; renewed the various treaties between them and the United States by which their lands were guaranteed to them, treaties

${ }^{2}$ Payne Mss. 2, p. 383; Cong. Doc. 315, No. 120, p. 543.

${ }^{27}$ Cong. Doc. 315, No. 120, p. 529. Statement by John Ridge.

${ }^{28}$ March 5, 1831. 
which the Cherokees had always faithfully observed; claimed for themselves the benefit of the clause in the constitution declaring treaties the supreme law of the land; complained of the violation of the treaties by the state of Georgia; claimed the protection of the United States against the state and asked the court to declare null and void the laws of Georgia which interfered with the ancient rights and privileges of the tribe. ${ }^{29}$ The motion for injunction was denied on the ground that the Cherokee Nation was not a foreign state in the sense of the constitution and could not maintain an action in the courts of the United States, Chief Justice Marshall and Justice Story dissenting from the opinion of the majority of the court.

The laws of 1830 in regard to white persons residing in the Cherokee Nation were aimed at gold diggers and intermarried white men suspected of encouraging opposition to removal. But a week after the passage of the law, the whole body of missionaries in the Cherokee Nation brought themselves under its ban by holding a meeting at New Echota where they passed resolutions exonerating themselves from the charge of meddling in Indian politics, and declaring their conviction that removal of the Indians would seriously retard their progress in civilization and that the extension of Georgia's jurisdiction would work an immense and irreparable injury. When called upon to retract or leave the nation they refused to do either, whereupon Dr. S. A. Worcester and J. Thompson, two ordained missionaries and Isaac Procter, a teacher, were arrested by the Georgia Guard, chained together in pairs and taken to headquarters seventy or eighty miles away with considerable military display designed to impress the Indians. ${ }^{30}$ After a preliminary trial they were dismised on the ground that they were agents of the United States as dispensers of the civilization fund. ${ }^{31}$ Governor Gilmer dissented from the opinion of the judge. After communicating with Secretary Eaton, he found that seven of the nine missionaries residing in the Cherokee

${ }^{29}$ The Cherokee Nation vs. Georgia, Peters' Supreme Court Reports, Vol. 5, p. 1; Niles' Register 39, pp. 31, 338, 339.

${ }^{30}$ Niles 40, p. 297.

${ }^{31}$ Missionary Herald, March, 1831, Vol. XXVII, 79-84; Niles 40, p. 132. 
Nation were supported entirely by the American Board ${ }^{32}$ and that only one of them, Dr. Worcester who was postmaster at New Echota, could in any way be considered an agent of the United States. Dr. Worcester was particularly objectionable to Georgia because of his connection with the Cherokee Phoenix which had published a number of articles exposing the true situation in regard to removal and the aggression of the state, appealing strongly to the sympathy of the North and East. He was at once deprived of his secular office in order to make him fully amenable to Georgia. Thereupon the missionaries were again arrested with great cruelty and brought before a Georgia tribunal where Dr. Worcester and Mr. Elizur Butler, refusing to accept the governor's pardon by taking an oath of citizenship, were sentenced to four years' hard labor in the penitentiary where they were compelled to wear prison garb and work on the rock pile. ${ }^{33}$ The missionaries with Mr. Wirt as counsel appealed to the Supreme Court which in 1832 rendered the decision declaring unconstitutional those laws by which Georgia had extended her jurisdiction over Indian territory, and the one under which Dr. Worcester was indicted. ${ }^{34}$ News of the decision reaching the Cherokees late in March was like "a shower of rain on thirsty vegetation", 35 says Elijah Hicks. The feeling of depression and uncertainty vanished like the mists before the sun. The decision was celebrated by dances and feasts. The young people were merry, the older ones contented and happy. Once more the Cherokees seemed standing upon a solid foundation. ${ }^{36}$

Georgia was prepared to fight rather than submit to this decision. The President found himself in a dilemma and the whole country looked on to see what he would do. To South Carolina he declared, "the laws of the United States must be

${ }^{32}$ The Methodists and Moravians had recalled their missionaries. The American Board of Commissioners for Foreign Missions had left their missionaries to decide the question of leaving the country for themselves.

${ }^{33}$ Payne Mss. 7, 125-130.

${ }^{24}$ Niles 42 , pp. 40-56.

${ }^{35}$ Letter of Elijah Hicks to a friend in Washington, March 26, 1832. Niles 42, p. 201.

$*$ Ibid. 
executed. Those who told you that you might peaceably prevent their execution have deceived you. Their object is disunion, and disunion by armed force is treason". Mr. Ross, who, it would seem, had some ground for hope, confided to Council in October, 1833, that since the Supreme Court had decided the Cherokee case favorably and the President had declared the supremacy of the constitution and the laws of the United States over state authority there was every reason to believe that he would ultimately enforce the treaties and intercourse acts for their protection. ${ }^{37}$ "The people of the United States owe Jackson a deep debt of gratitude", says an American historian. "His name-a name of power for many years to come-was joined with the idea of union, and the supremacy of the constitution". ${ }^{38}$ It was the supremacy of the constitution as President Jackson chose to interpret it, however, that the doughty general would defend so gallantly, and not as the Supreme Court interpreted it. The highest tribunal of the land had spoken and its decision had been a victory for the Cherokees and for justice. The chief executive of the United States is said to have dismissed the subject quite cavalierly with the words, "John Marshall has made his decision, now let him enforce it". ${ }^{39}$ Verily consistency is not a jewel that adorns Andrew Jackson's crown, if, perchance, he wears one.

${ }^{37}$ Niles' Register 45, p. 127.

${ }^{3 s}$ McLaughlin's History of American Nation, p. 328.

${ }^{39}$ Greeley's American Conflict, I, p. 106. 


\section{CHAPTER VIII}

\section{Factional Strife}

The temper of the Scotch Indian chief, already severely tried, was yet to undergo a more severe test. His nation had been harassed by distractions from without. It now came to suffer dissentions within the body politic.

In 1828 Whitepath, a full-blood of the conservative type, had headed a rebellion against the new government and against the Christian religion which was at this time winning many converts. The Cherokee government succeeded in putting it down without serious trouble or bloodshed, and the leaders became reconciled to the new order of things, Whitepath becoming a member of Council under the constitution. A few irreconcilables remained, however, to become the nucleus of a party favorable to emigration. William Hicks joined them when he became estranged and embittered by his political defeat, ${ }^{1}$ and used what influence he possessed in adding recruits to the malcontents. This discontented group fell a ready prey to the machinations of designing white men. Benjamin F. Curry, sent by the Federal Government at the dictation of Georgia, to open enrolling agencies in the Cherokee Nation, ${ }^{2}$ together with his assistants, all Georgians, had lost no time in making friends of them. Another factor was added to the situation the same year when Wilson Lumpkin succeeded to the governorship of Georgia with the fixed determination to force removal. Thoroughly familiar with the Indian situation, having spent the winter of 1825-26 in the Cherokee Nation as a member of the board of public works, when he visited and conversed with all the prominent men of the tribe, he had already laid the foundation for the influence he was prepared to wield for removal. Federal and state officials joined forces, halting at no means or method to accomplish their purpose. By resorting to bribery and intrigue the most disgraceful, and manipulations the most subtle, they succeeded in detaching

${ }^{1}$ Payne Mss. 6; Mooney, Myths of the Cherokees, pp. 113, 114.

${ }^{2}$ Abel, Indian Consolidation, p. 402. 
some of the most prominent and some of the strongest men of the Cherokee Nation from their own government and building up a faction favorable to removal. The factional breach, once started, kept growing broader and the removal project grew correspondingly brighter.

Georgia had anticipated important results from her law forbidding the Cherokees to hold assemblies within her limits. Omission of the Council to assemble was expected completely to demoralize the Cherokee government which was preparing to appoint a new delegation to Washington, and leave its citizens at the mercy of the Federal Government and the state. An attempt to meet would be an infringement of the Georgia law, and would give the Georgia Guard an excuse for arresting and hauling off to prison the leaders of the Cherokees. Chiefs Ross and Hicks were in favor of abiding strictly by the constitution and holding the regular session of the Council at New Echota, regardless of consequences. They were overruled, however, in a preliminary meeting of the Council held at the Ross home, the argument prevailing that they would inevitably be attacked by the Georgia Guard, and as the people would not see their chiefs and representatives dragged away ignominously without resistance, the consequences would be disastrous. ${ }^{3}$ Chatooga, Alabama, an old camp meeting ground, was chosen as the meeting place of the General Council of 1831. Here rude sheds were made by laying rough boards on poles supported by forked stakes driven into the ground, while logs arranged in rows furnished benches for council and judges, as well as for the great crowd of people, who, according to ancient custom, were in attendance. ${ }^{4}$ Chatooga proved too remote from the main body of the tribe, however, and Red Clay in southern Tennessee was chosen as the place of the next meeting. ${ }^{5}$ This proved more convenient and remained the capital as long as the Cherokees remained in the East.

The terms for which the chiefs and members of the legislature were elected expired at the closc of the first session of

${ }^{3}$ Payne Mss. 2, p. 359.

${ }^{4}$ Ibid, p. 361.

${ }^{5}$ Ibid 2, pp. 317-373. 
Council held at Red Clay. According to the constitution, a new election would take place the following summer before the next meeting of Council. Inasmuch as the confusion caused by the Georgia laws prevented elections in the regular manner the Council referred the question to the people, a large number of whom was in attendance. They called a convention forthwith on the council ground and representatives from the different districts were chosen from among those present. This convention passed a resolution continuing in office "the present national executive, legislative and judicial officials, the same being the people's last choice". Until elections could be held constitutionally, vacancies were to be filled by the Principal Chief, subject to the approval of the upper house. ${ }^{6}$

The action of this convention was far from gratifying to the Ridges and their friends who were beginning to lose favor with the administration on account of rumors of disaffection and leanings toward removal. Friendly association with removal agents gave color to these reports and John Ridge was impeached by the Council on complaints filed by his own district on the ground that he no longer represented the opinion of the district. Major Ridge and David Vann were next impeached for advancing policies contrary to those of the majority. No trial was ever held, it being the chiefs' policy to avoid arousing antagonism, and all three resigned. ${ }^{7}$ Elias Boudinot resigned from the editorship of the Phoenix in 1832 because Mr. Ross discouraged a free discussion of the removal policy $^{8}$ and with the Ridges and Vanns went over to the opposition which had gained a sufficient following by 1835 to organize a party ${ }^{9}$ with $\mathrm{Wm}$. Hicks as Principal Chief and John McIntosh Second Chief. A legislature was appointed and steps were taken to supplant the existing government. Dissenters arose in their own ranks, however, and a large number of them emigrated. Among those left behind were the Ridges, Boudinot, Vann and Andrew Ross.

'Ibid, p. 369.

${ }^{7}$ Cong. Doc. 315, No. 121.

${ }^{8}$ Cong. Doc. 315, No. 121.

${ }^{\circ}$ Niles' Register 47, p. 353. 
The two Ridges and Boudinot, because of their superior ability and influence, soon became recognized as leaders of the opposition party both by the Cherokees and the Federal authorities. Of Major Ridge and his nephew, Elias Boudinot, some account has been given in preceding chapters. John Ridge, educated in New England, was a young man of great promise, handsome, brilliant and ambitious. ${ }^{10}$ After completing his education he returned with his Connecticut bride to the Cherokee Nation to enter with all the ardor and enthusiasm of confident youth into the political and social life of the tribe. His superior education, his eloquence, his distinguished appearance, enhanced by his taste for handsome apparel in which his father's wealth permitted him to indulge, his fondness for distinction and power, (all characteristics of the young men of the ruling class throughout the south) gave him the reputation of being the most promising young man of the Cherokee Nation. When in $\mathbf{1 8 3 2}$ he and Elias Boudinot made a tour of the east, addressing enthusiastic audiences in New York and Boston on the condition of their people, all who heard him were impressed with his gentlemanly bearing and stirring eloquence. ${ }^{11}$

Young Ridge naturally desired and expected some day to occupy the highest position which his government had to offer. His political career began auspiciously when he became a member of the National Committee of which his father was president, his popularity and reputation for tribal patriotism reaching its zenith when he brought to bear all his influence for the renewal of a law, the provisions of which had been drafted by his father, making it a death penalty for any person or group of persons to sell Cherokee land without the consent of the Council. As long as there was any hope of attaining the chieftainship, the way to which was temporarily blocked by the superior influence of a man in some respects seemingly inferior to him, Ridge was content to bide his time. But when the Council of 1831 made John Ross chief executive indefinitely, Ridge saw his chances of political advancement utterly destroyed, unless the uncertainty of the times should work some change more advantageous

${ }^{10}$ McKenney and Hall, Indian Tribes of North America, Vol. II, pp. 103-106 (1855).

${ }^{11}$ Niles' Register 56, p. 342. 
to his prospects. Little by little an estrangement grew up between Ross and Ridge with his coterie of friends and admirers which government and state agents eagerly seized upon. The Ridges hitherto had consistently opposed emigration. Now they began to look upon it more favorably. Readjustment in a new country might give them the political opportunity which would be denied them indefinitely in the east.

But the motives that prompted them were not altogether selfish and personal. They were men of honor and patriotism, conscious of the possibilities of the misuse of power concentrated in the hands of one man with strong political backing, with unlimited tenure of office and the control of the purse strings. To be sure the purse was now empty, but it would not always be so; when the annuities were paid the money could be used greatly to the advantage and profit of those in control of the government. Some of these men of the opposition party were undoubtedly high-minded, far-sighted men who, honestly convinced that their people could never be restored to peace and happiness in the east, and seeing the futility of further resisting the Federal Government, took what appealed to them as the only way out of the difficulty. They now came out boldly against the Ross party and worked openly for removal.

Thus. before it had been launched three years the very existence of the Cherokee republic was being threatened from within and without. No one appreciated its situation more keenly than the captain of the small craft of state who, with every faculty alert, bent all his energy to the task of quelling the mutiny on board while weathering the tempest steadily growing darker and fiercer without, threatening to overwhelm him and his people in shipwreck and ruin. Sustained by his Christian optimism he kept a clear head and a steady hand, firmly believing that the justice of the Cherokee cause would finally triumph and that a quiet harbor could yet be reached if domestic peace and harmony could be restored, and forbearance and patience maintained towards the disturbing elements without. Appealing to his people as well as to a higher power than his own or theirs he issued a proclamation recommending July nineteenth to be observed as a day of fasting and prayer 
out the Cherokee Nation. The proclamation declared, "We have need to go to the Ruler of the Universe in this day of deep affliction. We have been too long trusting to an arm of flesh which has proved to be but a broken reed", ("Happy is he who hath the God of Jacob for his refuge",- - that God "which keepeth truth forever, which executeth judgment for the oppressed".) and whether the time of tribulation and sorrow through which they were passing was caused by the wanton depravity and wickedness of man or by the unsearchable and mysterious will of a wise Providence it equally became them as a rational and Christian community humbly to bow in humiliation. ${ }^{12}$

The majority of the tribe responded and on the day appointed age and youth, middle age and childhood, repaired to camp meeting grounds, to convenient groves or dwellings, and fasted and prayed. The occasion was profoundly dignified and impressive. Ross knelt and prayed with his people and arose to resume his duties refreshed in spirit and entrenched in the hearts of his tribesmen whose abiding faith in him was to stand the test of bribery and intrigue, of lying and calumny to the end of his long and stormy career.

${ }^{12}$ Niles' Register 42, p. 441; Cherokee Phoenix, July 7, 1832 ; Drake's Indians, p. 458 (1880). 


\section{CHAPTER IX}

\section{The National Executive Refuses Protection}

\section{TO THE INDIANS}

Chief Ross, with a delegation, spent the following winter in Washington, bringing to bear every influence at his command upon the President and Congress to furnish some relief to the Cherokees. But the only course offered was removal. Finally in a communication dated January 28, 1833, the chief assured the executive that notwithstanding the various perplexities the Cherokees had experienced they were yet unshaken in their objection to removal. They had no assurance that removal westward would not be followed in a few years by consequences no less fatal than those which they were then suffering. $\mathrm{He}$ then suggested that the government satisfy those Georgians who had taken possession of Cherokee land under the lottery drawing by assigning them unoccupied lands in other territories. ${ }^{1}$ Secretary Cass replied that he could not foresee any cause for fearing that removal would be injurious either in its immediate or remote consequences. A mild climate, a fertile soil, an inviting and extensive country, a government of their own, adequate protection against other Indians and against United States citizens, pecuniary means for removal, all were offered them. Mr. Cass could not see the subject in the melancholy light in which the Cherokees had presented it.

He urged that it was only by removal they could find a safe retreat for themselves since "as long as any remained in Georgia they were subject to the laws of that state, surrounded by white settlements and exposed to all those evils which had always attended the Indian race when placed in immediate contact with the white population. It was only by removing them that they could expect to avoid the fate which had already swept away so many Indian tribes." Ross replied with deep regret, he felt constrained to say, that in this scheme for Indian removal, he could see more of expediency and policy to get rid of the Cherokee than to perpetuate their race upon any

${ }^{1}$ Cong. Doc. 268, No. 71, p. 29. 
permanent fundamental principle. If the doctrine, that they could not exist contiguous to a white population, should prevail and they should be compelled to remove west of the states and territories of the republic, what was to prevent a similar removal of them from that place for the same reason? ${ }^{2}$

The delegation returned home in March without having secured any promise of relief or any encouragement whatever from the executive. Ross agreed, before leaving Washington, however, to submit to the Council a proposition to pay the Cherokees $\$ 2,500,00$ for their land if they would remove at their own expense. The President appointed Benj. F. Curry to represent the interests of the government at the meeting of Council called for the purpose of receiving the report of the delegation. Mr. Curry left no stone unturned in his zeal for securing a treaty of cession. A bribe of $\$ 5,000$ very adroitly proposed to the principal chief ${ }^{3}$ by one of Curry's accomplices and spurned by the chief with bitter contempt, caused the commissioner to lose the last vestige of respect in the eyes of the Indians who already hated him cordially. The Council refused to accept the President's terms and adjourned, after having appointed another delegation to Washington the following month.

The condition of the Cherokees was now becoming worse and worse. Deprived of their annuity funds, the country demoralized politically and economically, ${ }^{4}$ the Indians were suffering. They could no longer look for relief from Washington. The factional fight grew more bitter day by day and fresh recruits were being added to the party in favor of a treaty.

To add to the confusion, the Georgia legislature, as has been mentioned before, had passed an act which granted to fortunate drawers of lots the lands occupied by the improvements of those Indians who had accepted reservations under former treaties. This act included the improvements of all who had enrolled for emigration and after having accepted pay for

${ }^{2}$ Ibid, pp. 30-31.

${ }^{3}$ Commissioner of Indian Affairs to Agent Montgomery, April 22, 1833. Indian Office Manuscript Records; Cherokee Phoenix, March 6, 1832.

${ }^{4}$ Niles' Register 44, p. 230. 
their improvements had remained in the Nation. ${ }^{5}$ Additional legislation at the same session was passed to induce removal. The next year a law granting possession of these lots was a signal for worse depredations than any formerly committed. Some of the best Cherokee homesteads were seized, live stock confiscated, and owners ejected from their homes. Georgians who had never before lived in anything but a one-room log cabin found themselves ensconced in comfortable and commodious quarters. One Georgia lottery gambler, whose sole possessions consisted of the clothes he wore and two or three pistols, drew the lot belonging to an industrious Indian boy ${ }^{6}$ who had improved his premises until they were of considerable value. The gambler loaded up his possessions, and, "leaving his low vaulted past", went into the Cherokee country, entered the house of the Indian, took possession of the comfortable buildings and cultivated fields and "stretched himself in his new found home and knew the old no more". " Charles Hicks was forced to vacate his pleasant and comfortable home in the dead of winter and move his family to Tennessee, where they found shelter in an old sugar camp. ${ }^{8}$ Mr. Martin, the Cherokee treasurer, received notice from the state agent, Colonel Bishop, on January 20 that he must prepare to give entire possession of his premises in the next thirty days or suffer the penalty of the law. ${ }^{9}$ His carved mantels and marble hearths were part of the prize that fell to another fortunate Georgian.

Hundreds of other cases might be added, but it is useless to multiply examples to show that in her determination to cleanse her soil of the aborigines the state and her citizens were prepared to go to any length, though all the while strenuously disavowing any selfish or sinister motives toward the Indians. ${ }^{10}$ One other instance is of interest, however, as showing how state officials took advantage of legal technicalities to further the interests of friends and relatives. The case is that of Joseph Vann,

Ibid, p. 231.

${ }^{6}$ Ibid, p. 270.

'Holmes's Chambered Nautilus.

${ }^{8}$ Payne Mss. 2.

- Cong. Doc. 296, No. 286, p. 5.

${ }^{10}$ Ibid, p. 6. 
a rich planter of Vann's Spring Place, ${ }^{11}$ whose plantation contained about eight hundred acres of cultivated land. His improvements consisted of a brick house, costing about ten thousand dollars, mills, kitchens, negro quarters, gardens and apple and peach orchards, a rare prize not to be disposed of by lottery. Mr. Vann's estate was so extensive he was compelled to employ an overseer. In the fall of 1833 he was called away from home on business. Before going he made a conditional contract with a Mr. Howell, a white man, to superintend his plantation for him during the year beginning January 1, 1834. On returning home in the latter part of December and learning of a state law prohibiting a Cherokee from hiring a white man, Vann promptly canceled his contract with Howell. The state agent, Mr. Bishop, notwithstanding, notified the Georgia authorities that Vann had violated the state laws by hiring a white man, thereby forfeiting his right of occupancy. Conflicting claims for possession arose between the state agent and a Mr. Riley. Riley took possession of the upper part of the dwelling armed for a siege. When Bishop and his party arrived a pitched battle ensued. Riley could not be dislodged and Bishop set fire to the house. Riley then surrendered and the fire was extinguished. Vann with his frightened household, in the meantime, had taken refuge in a remote room of the house. After the smoke of battle cleared away they were driven out and forced to make their way over the snow-covered fields into the limits of Tennessee. Here they found shelter in an open log cabin with a dirt floor. Mr. Bishop's brother, Absolam, moved into the Vann mansion and took possession of the estate. ${ }^{12}$

Outrages were perpetrated upon the poor as well as upon the prosperous. The suffering and destitution of these helpless victims was pitiful to see; their story is too heartrending to dwell upon. ${ }^{13}$ Yet the Cherokees remained unshaken in their

${ }^{11}$ It will be remembered that the first mission station in the Cherokee nation had been established here with the help of Vann's father. Joseph Vann as a boy had fought in the Creek war and was one of those who periled his life crossing the river in the Battle of the Horse Shoe.

${ }^{12}$ Cong. Doc. 292, No. 286, pp. 6 and 7.

${ }^{18}$ Other instances of outrages are described in Cong. Doc. 208, No. 57, page 7 . 
determination not to remove. Devotion to established customs and to their ancestral homes was deeply rooted. They chose to bear the ills they had rather than fly to others they knew not of.

When the fall Council met in $\mathbf{1 8 3 3}$ it took up the discussion of the situation and the advantage to be gained by giving up their tribal identity and becoming citizens of the United States. A memorial was drawn up, in which, after asserting that they would never voluntarily give up their homes, they consented to satisfy Georgia by ceding part of their land on condition that the Federal Government protect them in the remainder until a definite time to be fixed by the United States, after which time they should become citizens of the United States. ${ }^{14}$ This memorial was dispatched to Washington by John Ross, heading a delegation. The reply from the executive lacked originality. Removal was the only remedy for their troubles.

In the meantime there had appeared at the National Capital three Cherokees representing the faction favoring removal. Andrew Ross, the leader, suggested to the Commissioner of Indian affairs that if authorized to do so, he would return to the Cherokee Nation and bring to Washington a delegation with whom a treaty could be effected for the whole or a part of the Cherokee territory. Andrew Ross was a man of extravagant tastes and an elastic code of ethics. Having become deeply involved in debt, he had easily fallen in with the intrigues of Benj. F. Curry who engaged him as enrolling agent for the amount of his debt. ${ }^{15}$ He had enrolled for the west and according to a law of the nation had no legal or moral right to take any hand in the affairs of the eastern nation. President Jackson was able to overlook these small considerations, however, and Andrew Ross's plan was accepted. It was agreed that if a treaty should be concluded, the United States would pay the expenses of the delegation.

Returning home, Andrew Ross assembled about two dozen of the treaty faction at the agency and succeeded in organizing the Treaty party with William Hicks as principal chief and John McIntosh, second chief. A legislature was appointed

${ }^{14}$ Cherokee Phoenix, October 12, 1833.

${ }^{15}$ Payne Mss. 2. 
and other steps taken to supplant the regularly constituted government. Eight of their number, selected as a delegation to Washington arrived at the National Capital in May, a little more than two months after Ross had first broached the subject of removal to the Commissioner of Indian Affairs. This was quick work considering the length of the round trip which was made on horseback, the organization of a government and the selection of a group of men to represent it at a foreign capital.

Honorable J. H. Eaton was appointed commissioner to confer with them. After negotiations were commenced he notified John Ross of what was being done and invited him to coöperate with them. The chief refused this proposal, hotly saying, "In the face of Heaven and earth, before God and man, I most solemnly protest against any treaty being entered into with those of whom you say one is in progress so as to affect the rights and interests of the Cherokee Nation East of the Mississippi River". ${ }^{16}$ Ross then notified the Cherokee Council of the business in progress and a protest signed by thirteen thousand Cherokees was sent up to Washington and presented by the chief only to be disregarded under the plea that some of the signatures were fictitious. ${ }^{17}$ The proceedings continued and a preliminary treaty was drawn up, June 19, which neither Major Ridge nor John Ridge signed, though both were present. ${ }^{18}$ Its provisions included no terms more advantageous than those previously offered and when it was presented to the Cherokees they refused to ratify it. The whole business had proved a fiasco so far as the Federal Government was concerned. The Council called to ratify it held a stormy session, for members of both parties attended. John Walker, Jr., one of the principal advocates of removal, was shot and killed while on his way home from the meeting, and, while the motive that prompted the assassination was a personal one, the affair caused intense excitement through the Cherokee Nation. Accusation, recrimination and threats were freely bandied about and a tribal war seemed imminent. The tact and ingenuity of the principal chief was taxed to the utmost to prevent further bloodshed and restore a measure of tranquillity to the nation.

${ }^{16}$ Cong. Doc. 268, No. 71, p. 6.

${ }^{17}$ Ibid, p. 7.

${ }^{18}$ Cong. Doc. 292, No. 286, pp. 135, 6. 


\section{CHAPTER $\mathrm{X}$ \\ The Annuity Plot}

When the regular session of the Cherokee Council met at Red Clay in October ${ }^{1}$ excitement still ran high. The disposition of the Federal executive to recognize the "set of unauthorized individuals calling themselves the Treaty Party" spread consternation and aroused indignation throughout the main body of the tribe now beginning to call themselves the National party.

A delegation was sent to Washington instructed to circumvent the treaty men at all hazards. If a treaty must be made, as they were beginning to fear was inevitable, then it should be made with the regularly constituted government of the tribe. In the winter of 1835, therefore, two rival delegations, one headed by John Ross, the other by Major Ridge, again went up to Washington.

The Secretary of War first recognized the Ross deputation, offering them practically the same terms as had been recently rejected by the Council. They declined to accept them. He then turned to the Ridge faction which manifested a more compliant attitude, and commissioned the Reverend J. F. Schermerhorn to negotiate a treaty with them. ${ }^{2}$ Hearing of this before negotiations had been opened, Ross asked the President to permit him to submit a proposition for a treaty. ${ }^{3}$ The request was granted and operations with Ridge were suspended for a time. It was two weeks before Ross presented his proposition which offered to cede the Cherokee Country East for twenty million dollars. This sum the President considered too exorbitant to be considered seriously and charged Ross with insincerity and with filibustering. In order to prove his sincerity and at the same time test the temper of the Senate, among whose members the Cherokees had strong friends, Ross next offered to allow the Senate to decide the sum tentatively,

1834.

${ }^{2}$ Cong. Doc. 315, No. 120, p. 455.

'Cong. Doc. 292, No. 286, pp. 132, 133. 
the question ultimately to be submitted to the Cherokee Nation. ${ }^{4}$ This move proved an unfortunate one for John Ross and the Cherokees. His proposal was at once accepted and a statement of all the facts in the case in the form of a memorial was sent to the Senate Committee on Indian Affairs with Senator King of Georgia as chairman. In less than a week the Secretary of War informed Chief Ross that in the opinion of the Senate not more than five million dollars should be paid the Cherokees for their possessions east of the Mississippi River. He then invited the Ross delegation to enter into negotiations on that basis. The invitation was declined. ${ }^{5}$

Meanwhile, in order to make assurance doubly sure, President Jackson had ordered Schermerhorn to proceed with the negotiations with the opposing party. On February 28 an agreement was drawn up with them in which the consideration for the Cherokee lands east was fixed at four million, five hundred thousand dollars. This treaty was taken up after Ross had rejected the Senate proposition and, on March 14, was signed with the express stipulation that it should receive the approval of the Cherokee people in full Council assembled before it should be considered binding.

President Jackson's next concern was to have the treaty ratified. To this end he issued an address to the Cherokees, calling them "Brothers," inviting them to a calm consideration of their condition and prospects and urging upon them the benefit certain to inure to their nation by the ratification of the treaty and their removal to the western country. ${ }^{6}$ This address he dispatched by Mr. Schermerhorn, who had been appointed Commissioner to complete the negotiations of the treaty in the Cherokee Nation. ${ }^{\text {? }}$

The Treaty delegation, realizing their personal safety was at stake, had hastened home, arriving ten days or two weeks

${ }^{4}$ Ibid, p. 141.

${ }^{5}$ Ibid, p. 142.

'Ibid, p. 41.

${ }^{7}$ General William Carroll was appointed on the commission also, but on account of an affliction of rheumatism was unable to proceed to the Cherokee Nation. So Mr. Schermerhorn was left to conduct the negotiations alone. 
in advance of their rivals, and promptly undertaken to get the reins of government into their own hands. As they were now practically the agents of the Federal Government they looked to its officials for support, nor did they look in vain. Major Curry, who was still holding up the annuities and using them as a pretext to call the Indians together for the purpose of urging removal, circulated the notice for a meeting to be held at the head of the Coosa ${ }^{8}$ River, the first Monday in May, with the object of determining in what manner the annuities should be paid. The Treaty men called a meeting for the same time and place to explain what had been done at Washington. It was hoped, by confusing the two calls, to collect a large crowd, make a display of popularity for the Treaty men and give them control of the purse strings and the upper hand in the government which they could use for their own protection and for furthering the plans of the administration.

The meeting proved a failure in spite of Curry's threat to pay the annuities to the person selected at that place, even if there should be only four in attendance. Fewer than a hundred were present, of whom twenty-five or thirty were Cherokees, chiefly emigrants, and the remainder Georgians. No vote was attempted. A less persistent and resourceful man would have acknowledged himself defeated. Not so Major Curry. He merely posted the notice of another meeting to be held at the same place on July 20 for the purpose of determining in what manner the annuities should be paid. ${ }^{9}$

In the meantime Mr. Ross returned to the Cherokee Nation to find his family ejected by an enterprising Georgian who had drawn their home in the land lottery, ${ }^{10}$ and the people in much confusion and perplexity of mind over the reports of the treaty.

A council which he called to meet at Red Clay the second week in May was well attended. A vote taken on the New Echota 'Treaty and the payment of the annuities showed that the Indians had changed their minds on neither subject.

${ }^{8}$ In the neighborhood of Ridge's home; Payne Mss. 2, p. 398.

${ }^{\circ}$ Payne Mss. 2, pp. 279-290.

${ }^{10}$ Cong. Doc. 292, No. 286, p. 10. Mr. Ross's family sought refuge beyond the borders of Georgia within the limits of Tennessee, where they lived in a log cabin until 1838. 
Immediately on the adjournment of the Council Mr. Ross went up to the agency to see what would be done about the payment of annuities. While at Washington he had been informed that the money was in the hands of Lieutenant Bateman ready to be turned over as soon as the Cherokees had fully determined upon the manner in which they should be paid. Bateman informed him that a vote would have to be taken at the meeting in July on the Coosa, and the money would then be paid over even if there should not be more than ten present. The reason of this choice of meeting place was not far to seek. It was in Georgia, in range of the Georgia Guard, and the chiefs could not attend without danger of arrest. Whispered threats had been circulated with the express purpose of keeping them away. The Indians who atended would therefore be influenced by the Treaty party and the annuity could then fall an easy prize to that faction. It was expected that the majority of the people would follow the purse.

While Ross was still at his brother's ${ }^{11}$ in the vicinity of the Agency, the President's emissary, Mr. Schermerhorn, arrived and immediately set about prosecuting his mission with a zeal worthy of a better cause. He first requested an interview with the Principal Chief. It was cheerfully granted. During the conversation the Commissioner expressed a desire to meet the leading men of the tribe, saying "I would deem myself extremely fortunate if $I$ could in any way be the means of bringing together and to a general close by a treaty the unhappy difficulties existing between you and the United States."12 Ross declared his willingness to arrange such a meeting to be held at Red Clay. The Commissioner hesitated, and after consulting with Agent Curry, declined, insisting upon meeting them on July 20 at Ridge's.

It now seemed perfectly obvious that neither the Commissioner nor the Agent was acting in good faith. A full attendance at the meeting was neither expected nor desired. The time selected was inconvenient. The Indians but lately returned from the call Council were occupied in making their

${ }^{11}$ Lewis Ross.

${ }_{12}$ Payne Mss. 2, p. 381. 
crops. The country, two hundred miles long by seventy wide, had to be traversed by runners and retraversed by the people within ten days. Moreover the people must bring with them provisions of food which had to be gathered and prepared. The Nationalists saw through the scheme and determined to thwart it. They dispatched messengers to all parts of the Nation requesting the people to assemble at Two $\operatorname{Run}^{13}$ on the evening of July 19 if possible. The message was obeyed promptly and the people began preparations for the journey. As the time of meeting approached the weather grew threatening. A heavy cloud enveloped the mountain tops and on July 19 a cold rain began to fall. It must have seemed to the Cherokees that the very elements were leagued against them. On the night appointed small parties met at the appointed place. Early the next morning two large parties arrived, one of four or five hundred from the neighborhood of Second Chief Lowrey's, who was among them. Many of these were old men who had traveled the hundred miles on foot. Other parties appeared from time to time until the number was swelled to more than two thousand.

Curry and Schermerhorn had reckoned without their host. Astonishment, consternation, and fear seized upon their camp which was a mere handful compared with the great throng gathering from all parts of the Cherokee Nation. By nine o'clock an orderly audience, gathered at the place of meeting, awaited the arrival of Major Curry who was a guest at the home of John Ridge near by. The raw and gloomy day wore on and still he did not appear. Ross finally sent a messenger beseeching him to come as soon as possible and relieve the people from exposure to the inclement weather by transacting promptly the business which had brought him there. At length he appeared and then ensued another delay as Schermerhorn had not yet arrived and Curry declared he could not proceed without him. Finally, all parties having assembled, Curry ascending the platform, asked Ross if he objected to opening with prayer. "Certainly not", replied the Chief, "but I wish to open without further delay for we are overwhelmed with rain

${ }^{13}$ A creek about two miles from Ridge's. 
and numbers". A native preacher thereupon opened with prayer in the Cherokee language, and a hymn in the same tongue followed. No sooner was the hymn started than the Georgia Guard struck up an accompaniment with fife and drum, a sort of hint it seemed to the Indians that the persuasions of the Bible were to be reinforced by those of the sword. 'The devotional exercises concluded, Curry proceeded to business and after some delay the voting began. Archilla Smith, an Arkansas Cherokee, handed the agent a resolution, proposing that the annuities be used for the poor and the decrepit. Mr. Ross here interposed declaring that the meeting had not been called for the purpose of legislation. They were not in Council assembled to determine what to do with the money when they got it. 'To his mind the only question that could be put to them was one upon the act of Congress as to whether it should be paid the treasurer already appointed by them to receive it or whether each man would receive his own share. After another delay the voting finally began and proceeded under Major Curry's direction. As the Indians came up to cast their ballots Curry asked them if they did not want money and complained of the "bush speeches" made to mislead them, alluding, of course, to Ross whom he accused of secretly influencing them. They met his questions and insinuations with silence or a few terse words in their own language, which he could not understand, and proceeded to cast their votes.

The voting did not get beyond one district the first day. Towards evening Schermerhorn, fearing the failure of all his schemes, expressed the desire to speak to the people on the subject of his business to the nation. Ross insisted on proceeding with the regular business. The people were exposed to every sort of discomfort, and they were not provisioned for a long stay. The Indians themselves objected. They wanted to get through with the business in hand and return to their homes and their waiting crops. The commissioner overruled all protests, however, and insisted upon being heard the next day, promising to subsist ${ }^{14}$ them at government expense. When morning came he mounted the platform and proceeded

${ }^{14}$ Cong. Doc. 315, No. 120, p. 455. 
to address them for three hours and twenty minutes, cautioning the people against listening to bad birds bringing bad reports to excite prejudice against him, and treating them to a short history of himself and how he had become acquainted with his friend, President Jackson. He had stopped at Jackson's house for a call one day, and while there his horse had suddenly sickened and died, whereupon the President had sent him on his way rejoicing on a better steed and a finer mission. From his earliest recollections it had been the dream of his ambition to be useful to the Indians. His dream was coming true: as the President's representative he had come with a great message to them. He entreated them to "take warning from the fate of the tribes of the North and emigrate and live; not like them remain and rot."15 He assured them that it was the part of wisdom to accept the treaty and five million dollars for their Nation. "Take this money, for if you do not the bordering states will forthwith turn the screw tighter and tighter till you are ground to powder. And look not for mercy, for the measures of the present ruler of America will not change with his successor whom I know as I do myself. Do you complain of wrongs? Remove and you can retaliate. If the white man here oppress you, there you can oppress him. If he sticks you here, you can stick him there." 16

This harangue ended, the voting was continued but not finished that day. When night began to fall the Indians withdrew to the camp ground where temporary tents were made by covering a framework of poles with leafy branches. These tents were arranged around a hollow square in which large fires were lighted. Around the fires, or in the tents, the Indians gathered in groups to eat their scanty supper and to discuss the events of the day and the possibilities of the morrow. The scene, as described by John Howard Payne, who was present, was unique and picturesque. The firelight, casting a glow over the great encampment, fell upon the grave, swarthy faces of hundreds of men terribly in earnest concerning their national welfare, even their national existence, and revealed as

${ }^{16}$ Payne Mss. 2, p. 390.

${ }^{16} \mathrm{Mr}$. Schermerhorn, it will be remembered, was a Baptist preacher. 
the central figures of the scene the two trusted Chiefs, Ross and Lowrey, to whom all eyes turned for example and all ears for council. $^{17}$ The camp was perfectly orderly. There was no noise except the subdued sound of many voices in earnest conversation. Finally they grew more and more indistinct until they finally died away into complete silence and the multitude, worn out with the hardships and vexations of the day, slept. The sky cleared, the stars came out. Their soft light dimly revealed the outlines of the mountain tops but the valley of encampment remained in shadow.

The morning of the third day dawned clear and bright. The voting was continued. Curry and Schermerhorn with their colleagues seeing all their schemes frustrated encouraged various attempts to create disorder and confusion among the Indians. An attempt to get up a ball play for the purpose of distracting attention met with no response. Women were sent into the crowd with whiskey in the hope of creating a tumult, but the Indians ignored them. Several times the Georgia Guard mounted and galloped around the crowd to the guard house raising yells and starting mock pursuits. The Indians were on their guard. In one of these pursuits an emigrant got mixed up by mistake. He was released as soon as it was discovered he was not an Eastern Cherokee. Ross himself was not spared humiliating annoyances. An idiot boy took occasion to use insulting language to the Principal Chief. Some thought he had been set on to goad Ross to some act of indiscretion. The situation was met with such dignity and self-control as to appeal to the admiration of all who witnessed the incident.

At the close of the meeting Major Curry remarked to Mr. Ross that the assembly was the largest body of Indians he had ever seen or ever expected to see together and that it was extremely gratifying to him that so great a multitude should have been so orderly. To which Mr. Ross quietly replied: "Yes, I am most pleased with them because of the temptations which they have had the virtue to resist."

${ }^{17}$ Ridge had cordially invited Ross to spend the night under shelter of his roof. Courteously thanking him for his kindness he declined the invitation saying: "Why should I fare better than my people?" And he insisted upon sharing the accommodations of the common lot. 
The vote as concluded on the third day stood one hundred and fourteen for payment to individuals as against two thousand two hundred and twenty-five for payment to the National Treasurer. An attempt to pass a resolution that no part of the money should be used as attorney's fees was put down by acclamation. ${ }^{18}$

${ }^{18}$ An account of this meeting is given by John Howard Payne. Payne Mss. 2, pp. 379-400; Cong. Doc. 292, No. 286, p. 57. 


\section{CHAPTER XI}

\section{The New Echota Treaty}

During the summer and fall of 1835 Curry and Schermerhorn exhausted every available force to secure consent to a treaty, going so far as to importune the legislatures of Tennessee and Alabama to pass laws prohibiting Cherokees, ejected from their possessions in Georgia, from taking up residence in those states, Curry openly alleging it to be the policy of the United States to make the situation so miserable as to drive the Indians into a treaty or abandonment of the country. ${ }^{1}$ Indians were arrested and thrown into jail on the slightest excuse or none at all, held without trial and dismissed without explanation at the pleasure of the Georgia guard. ${ }^{2}$

For the express purpose of depleting the population of the eastern nation and weakening its government, thereby rendering it more amenable to the state and Federal policy, Agent Curry now redoubled his efforts in the direction of enrollment, halting at no methods to secure individual consent, or semblance of consent to emigrate. To this end he allowed whiskey to be brought into the Cherokee country and used freely among the Indians although their own laws forbade it; exercised the coarsest kind of intrigue among the more ignorant and helpless and where everything else failed he used force in securing enrollment. As evidence in this indictment there is the incident of Atahlah Anosta, a full-blood who, while drunk, was induced to enroll against the wishes of his wife and children. When the time came for him to leave for Arkansas he absconded. A guard sent to fetch him arrested his wife and children and drove them through a cold rain to the agency where they were detained under guard until the woman agreed to emigrate. ${ }^{3}$ There is also the story of Sconatachee, an Indian over eighty years of age, whose consent to register had been secured during a fit of drunkenness into which he had been inveigled by Curry's

${ }^{2}$ Cong. Doc. 282, No. 286, p. 8.

Ibid, p. 6 ; Payne Mss. 6.

B Ibid, p. 10. Payne Mss. 6. 
accomplices. When he failed to appear at the time the emigrants were collecting, Curry, with an interpreter, went after him. The Indian refused to accompany him, whereupon Curry drew a revolver and tried to drive the old fellow to the agency. Failing in this attempt he later sent a sufficient force to overpower and tie him hand ${ }^{4}$ and foot and thus the white haired chief of a once mighty race was hauled in a wagon to the agency like a hog to market.

But neither these measures nor others which the Federal officials had yet been able to devise seemed to incline the Indians to emigrate nor to render them more friendly to a treaty. Convinced that he was making poor headway, the commissioner finally wrote the Secretary of War suggesting that a treaty be concluded with a part of the nation only, should one with the whole be found impracticable. In reply, he was advised that if a treaty could not be concluded upon fair and open terms, he must abandon the effort and leave the nation to the consequences of its own stubbornness. ${ }^{5}$ But Mr. Schermerhorn, familiar with Jacksonian methods of dealing with the Indians, ${ }^{6}$ was able to read between the lines, and face to face with the fact that he must bring the Cherokees to terms very soon or lose favor with the President, he began to plan his course of action regardless of instructions, confident that a successful treaty would meet with executive approval and no questions asked.

As time for the October Council drew near, interest became centered in the proposed treaty. The Indians seemed to consider the approaching meeting of vital importance, and the attendance bade fair to be unusually large. Full-bloods from remote settlements, confused by rumors from various sources about a proposed treaty, and fearful of being led into a false situation by ignorance or intrigue, determined to consult Mr. Ross on the subject before Council convened.

On the morning of October $11,{ }^{7} 1835$, an interesting scene in the Cherokee drama was played. The place was a log cabin

$\therefore$ Cong. Doc. 282, No. 286, p. 10.

- Secretary of War to Schermerhorn, Sept. 26, 1835. Indian Office Manuscript Records; National Intelligencer, May 24, 1838.

- Schermerhorn to Secretary of War, Sept. 10, 1835.

'Council met October 12. 
meet him Mr. Ross went foward with grave dignity to give them his hand in greeting. The salutation over the old men remained near the Principal Chief while the rest of the company withdrew to different parts of the enclosure, some to repose Turk fashion on the ground with their backs against trees, others to sit upon logs, and still others, on the top of the rail fence. All eyes were fixed upon Chief Ross as he presently began to address them on the subject of their quest, while an interpreter stood ready to translate into Cherokee sentence by sentence. ${ }^{6}$ After explaining the provisions of the proposed treaty he told them plainly his opinion of it. According to his belief the terms it offered were not liberal enough and if they held off a while longer a fairer price could be obtained for their lands.

When he had finished speaking the men arose and as if with one impulse began to circle round the speaker expressing their approval of him by exclamations and ejaculations in the Indian language. ${ }^{7}$ Then an old man raising his voice above the noise of the multitudes spoke a few terse sentences, after which each one went for his pack and the march to the council ground was resumed. The dignity and solemnity of the occasion profoundly impressed all who witnessed the scene. ${ }^{8}$

When Council convened in October Mr. Schermerhorn and Mr. Curry were on hand to urge the merits of the treaty drawn up at Washington in the early spring. Their hopes ran high if we are to credit their correspondence at this time, their intention being to create a division in the National party, a part of whom could then be won over by hook or crook to unite with the Ridge faction in ageeing to the treaty. ${ }^{9}$ But they were doomed to surprise and disappointment for the unexpected again happened. The two factions had come together, as they had been trying to do since the Ridge meeting in June, and had agreed to bury in oblivion all unkindly feelings and to act unitedly

- While Mr. Ross spoke the Cherokee language in conversation with the Indians he made all his addresses in English and had them interpreted.

T This was in accordance with an ancient custom.

${ }^{8} \mathrm{~A}$ description of this event is to be found in an unsigned letter believed to have been written by John Howard Payne in the Cherokee Mss. Collection, Tahlequah, Okla.

${ }^{\circ}$ Cong. Doc. 315, No. 120, p. 485. Schermerhorn to Cass, Oct. 12, 1835. 
his opinion of it. According to his belief the terms it offered were not liberal enough and if they held off a while longer a fairer price could be obtained for their lands.

When he had finished speaking the men arose and as if with one impulse began to circle round the speaker expressing their approval of him by exclamations and ejaculations in the Indian language. ${ }^{9}$ Then an old man raising his voice above the noise of the multitudes spoke a few terse sentences, after which each one went for his pack and the march to the council ground was resumed. The dignity and solemnity of the occasion profoundly impressed all who witnessed the scene. ${ }^{10}$

When Council convened the next day Mr. Schermerhorn and Mr. Curry were on hand to urge the merits of the treaty drawn up at Washington in the early spring. Their hopes ran high if we are to credit their correspondence at this time, their intention being to create a division in the National party, a part of whom could then be won over by hook or crook to unite with the Ridge faction in agreeing to the treaty. ${ }^{11}$ But they were doomed to surprise and disappointment, for the unexpected again happened. The two factions had come together, as they had been trying to do since the Ridge meeting in June, and had agreed to bury in oblivion all unkindly feelings and to act unitedly, in arranging with the United States a treaty for the relief of the nation. ${ }^{12}$ As a result the Schermerhorn treaty was rejected unanimously by the Council, the Ridges and Boudinot using their influence against it. The astonished commissioner in reporting the affair to the Secretary of War acknowledged his disappointment in the unadvised and unexpected course taken by the Ridges, explaining it on the ground that they had become discouraged in contending with the power of Ross; he thought perhaps some consideration of personal safety may have had its influence also. "But," he piously observed, "the Lord is able to overrule all things for good."13 His chief hope

${ }^{\circ}$ This was in accordance with an ancient custom.

${ }^{10} \mathrm{~A}$ description of this event is to be found in an unsigned letter believed to have been written by John Howard Payne in the Cherokee Mss. Collection, Tahlequah, Okla.

${ }^{11}$ Cong. Doc. 315, No. 120, p. 485. Schermerhorn to Cass, Oct. 12, 1835.

${ }^{12}$ Cong. Doc. 292, No. 286, p. 82.

${ }^{13}$ National Intelligencer, May 24, 1828. 
in accomplishing a treaty now lay in the fear, on the part of the Indians, of Georgia legislation. Alabama and Tennessee, he thought, would pass some wholesome laws to quicken their movements. ${ }^{14}$ In order that he might have assurance of executive approval of steps already taken and support in occupying higher ground, Mr. Schermerhorn sent Major Curry on to Washington "with private dispatches of a confidential nature to the President and Secretary of War, part of which were verbal. ${ }^{15}$

In the glow of good feeling attending the reconciliation of the two factions, the Council passed a resolution providing for a committee of twenty members to be chosen from both parties and empowered to arrange a treaty with the commissioner in the Cherokee Nation or at Washington. ${ }^{16}$ John Ridge and Elias Boudinot were appointed members of this committee. Upon consulting Mr. Schermerhorn and finding that he had no authority to treat with them upon any other basis than the treaty just rejected the committee prepared to set out for Washington. But trouble was brewing among the newly reconciled parties. The Treaty men began to think that they were not sufficiently recognized on the committee and that due consideration had not been shown them by the Council. These and other grievances of a personal nature furnished fuel to the smouldering embers of factional enmity which were soon fanned into a blaze by assiduous Federal and state agents. Accusations and recriminations became the order of the day and resignations of the Ridge men from the committee naturally followed. First John Ridge resigned, and then Boudinot, and they were soon won back to their alliance with Mr. Schermerhorn. It would be interesting to know just how it was effected.

On the eve of the departure of the Nationalists for Washington Mr. Ross was seized by the Georgia Guard on the plea that he was a white man residing in the Indian country and conducted across the Georgia line where he was held for some time. ${ }^{17}$ The charge was too absurd to deceive any one, however,

${ }^{14}$ Cong. Doc. 315, No. 120, pp. 484 and 485 .

${ }^{15}$ Ibid, p. 485; also, 120.

${ }^{16}$ Ibid, p. 484.

${ }^{17}$ Curry to Cass, Nov. 3, 1835. Indian Office Letter 835, 1836. 
and he was finally released without trial or explanation. All his private correspondence, as well as the proceedings of Council, were seized at the same time and searched for incriminating evidence which would justify his removal from the scene of action. With him out of the way it was thought the Indians would be more easily managed. At the same time John Howard Payne, who was the guest of Ross and was in the nation for the purpose of collecting historical and ethnological material relating to the tribe, was seized and all his manuscripts rifled. A few weeks before this the Cherokee Phoenix had been suppressed and its plant seized and carried off by the Georgia Guard at the instigation of Major Curry, who saw that it was thereafter run in the interest of removal. ${ }^{18}$

Before leaving Red Clay, in October, Mr. Schermerhorn had posted on the walls of the council house notice of a meeting to be held at New Echota, the third week in December, for the purpose of agreeing to the terms of a treaty. The notice was accompanied by the threat that those who failed to attend would be counted as assenting to any treaty that might be made, and the promise that all who should attend would be subsisted at government expense. Threats and promises, however, proved of little avail, and when the proceedings opened there were present not more than three hundred Indians, men women and children. Of these a good many were emigrants, and none of them were principal officers of the Cherokee Nation. Curry, who had returned from Washington, evidently with the assurance of executive support, proceeded to carry things with a high hand, openly threatening any one who had come there to oppose the treaty agreement. ${ }^{19}$ At Mr. Schermerhorn's suggestion a committee of twenty was selected from among those present to confer with him as to details of a treaty. When it was reported to the people for their vote, the ballot showed seventynine in favor and seven against it. ${ }^{20} \mathrm{~A}$ delegation of thirteen was appointed to accompany the commissioner to Washington for the purpose of urging the ratification of the treaty, and clothed with power to assent to any alterations made necessary

${ }^{18}$ Payne Mss. 2.

${ }^{19}$ Cong. Doc. 315 , No. 120 , p.513.

${ }^{20}$ Ibid. 
by the President or Senate. Mr. Schermerhorn immediately wrote the Secretary of War of his success, exulting in the belief that John Ross was at last prostrate, the power of the nation having been taken from him as well as the money. ${ }^{21} \mathrm{He}$ was now a Sampson shorn of his locks.

The treat $y^{22}$ provided that the Cherokee Nation cede all its remaining territory east of the Mississippi River for the sum of four million five hundred dollars and a common joint interest in the country occupied by the Western Cherokees, with the addition of a small tract on the northeast. The Cherokees were to be paid for their improvements and removed and subsisted for a year at the expense of the United States, the removal to take place within two years from the ratification of the treaty. Provision was made for the payment of debts due from the Indians out of money coming to them from the treaty; for the reëstablishment of missions in the west; for pensions to the Cherokees wounded in the services of the government in the War of 1812 and the Creek war; for permission to establish such military posts and roads in the new country for the use of the United States as should be deemed necessary; for satisfying Osage claims in the western territory and for bringing about a friendly understanding between the two tribes; and for the commutation of all annuities into a permanent national fund, the interest to be placed at the disposal of the officers of the Cherokee Nation and by them disbursed, according to the will of their own people, for the care of schools and an orphan asylum, and for general national purposes. ${ }^{23}$ It was signed by J. F. Schermerhorn and William Carroll as commissioners of the United States and by the committee of twenty on the part of the Treaty party, prominent among whom were Major Ridge and Elias Boudinot.

The main body of the nation, amazed and indignant at what they considered the barefaced affrontery of their tribesmen, stood ready to contest the treaty. Second Chief Lowrey called a meeting of the Council at Red Clay in January, and although the weather was bitterly cold and stormy, and smallpox had

${ }^{21}$ Ibid, p. 495.

${ }^{22}$ Ibid, p. 512.

${ }_{23} 7$ U. S. Statutes at Large, p. 478 et seq. 
broken out in one district over four hundred persons were present. Those who were detained sent in votes by friends and neighbors. ${ }^{24}$ A resolution passed, denouncing the methods used by the commissioners and declaring the treaty null and void, was signed by upwards of twelve thousand Cherokees and forwarded to Washington. This protest with one signed by three thousand two hundred and fifty residing in North Carolina was presented to Congress by the Ross delegation, for while the Executive had shown too plain a hand in the game to leave any doubt as to what course he would now pursue it was still believed that the National Legislature would not stand for the methods used when the facts in the case became known. But in spite of the strenuous opposition against the ratification of the treaty it passed the Senate by a majority of one vote and was promptly signed and proclaimed by the President May 23, $1836{ }^{25}$ The treaty allowed the nation two years in which to remove and no time was lost by the administration in taking preliminary steps to carry it into execution. To Governor Lumpkin of Georgia and Governor Carroll of Tennessee who had been instrumental in bringing it about was given the commission to supervise and direct the execution of the treaty, while Benj. F. Curry was made superintendent of removal. The details of graft which crop out in the correspondence of the time as found in the official records prove that the removal of the Indians provided many a fat job for place hunters and friends of influential politicians on good terms with the administration. Many a political debt was paid with the capital furnished by the sale of the Cherokee Nation, East. ${ }^{26}$

${ }^{24}$ Cong. Doc. 292, No. 286, p. 118 ff.

${ }_{20} 7$ U. S. Statutes at Large, p. 478.

${ }^{26}$ Cong. Doc. 315, No. 120. Numerous letters to the President and Secretary of War. 


\section{CHAPTER XII}

\section{Opposition to the Treaty}

Mr. Ross remained in Washington until after the treaty passed the Senate, hoping that either sentiment against it or some technicality might defeat it. Seeking an interview with President Jackson he was bluntly informed that the Executive had ceased to recognize any existing government among the Eastern Cherokees.

On March 26 he wrote home advising his people to ignore the treaty but to remain quiet. ${ }^{1}$ A copy of this letter falling into the hands of his enemies was exploited as evidence of the Chief's intention to resist the treaty and called forth bitter denunciation from Federal and state officials who persisted in asserting that the majority of the Cherokees were in favor of removal and that all the trouble was due to Ross's efforts to arouse them to resistance. ${ }^{2}$ Rumors of a brewing insurrection supported by an anonymous letter warning white men in the Cherokee country of a plan to attack and drive them from the nation alarmed the administration and horrified the neighboring states. "When white men fight for home and country they are lauded as the noblest of patriots," says Miss Abel; "Indians doing the same thing are stigmatized as savages. What a fortunate and convenient excuse the doctrine of manifest destiny has proved." 3

But, as a matter of fact, the Indians had no intention of resorting to arms, as they attempted to prove by a meeting of representatives of the mountain districts held at Hiwassee in the summer of 1836, where they drew up resolutions stating the condition of their people and showing the futility of armed resistance. They had no military system, they said, no military supplies. The scalping knife and tomahawk had been buried half a century, while the love of war and the practice of it had become obsolete. A number of their old men still survived who

${ }^{1}$ Cong. Doc. 315, No. 120, p. 679.

${ }^{2}$ Ibid, p. 599.

Abel, Indian Consolidation, p. 266. 
had spilled their blood and had seen their brothers fall beside the Chief Magistrate of the United States; but their young men had never known war, had never heard the war whoop, nor "viewed the pitiless carnage of battle which wrings with hopeless agony the hearts of mothers, sisters and friends."

This protest with others of like tenor from different parts of the Cherokee country failed to restore public confidence and General Wool with an army of seven thousand men was sent late in July to overawe the Indians and to "frown down opposition to the treaty." In two meetings held soon after his arrival in North Carolina, where dwelt the least civilized portion of the tribe, he found the people peaceable but firmly opposed to the treaty. When they evaded the question of whether they would remove willingly he issued the ultimatum of peace or war, remove or fight. When they expressed the wish to consult John Ross the privilege was denied them on the ground that Ross had led them astray from their interests and happiness too long by his pernicious counsels. General Wool, they were told, was hereafter the most proper person to advise them. ${ }^{6}$ No decisive action having been taken when the meetings broke up, he sent out and overtook the chiefs, held them prisoners over night and released them only after they had promised to obey the treaty and send their young men in to surrender their arms. He reported to the Secretary of War that nineteentwentieths if not ninety-nine out of every one hundred of the North Carolina Cherokees were opposed to the treaty and would not comply with it unless compelled to do so by military force, and asked that additional troops be sent to his assistance. $^{7}$

Jackson's second term was now nearing its close and the Cherokees encouraged by friends in Congress entertained some expectation of relief from the next administration. In the summer of $1836 \mathrm{Mr}$. Ross had written a friend that if Mr. Clay and Mr. Frelinghuysen were elected it would be a godsend to the

${ }^{4}$ Niles' Register 50, p. 383.

- National Intelligencer, May 24, 1838.

- Cong. Doc. 315, No. 120, p. 170.

'Ibid, p. 629. 
country at large as well as to the poor Indian. ${ }^{8}$ Trusting to this forlorn hope the Indians held on, and removal came almost to a standstill. Announcements posted throughout the Cherokee Nation that a handsome steamboat stood ready to transport them in ease and luxury to the new country aroused no enthusiasm. Published addresses describing in the most alluring terms all the delights which the Cherokees could secure by removal and offering advantages the most exciting made no impression. Garbled documents attempting to prove that Chief Ross himself had consented to remove were unheeded. Complaints went up to Washington again and again that the Cherokees "would not come in."

The Council of 1836 adopted resolutions denouncing the motives of the United States commissioner in making the treaty, declaring the treaty null and void and asserting that it could never in justice be enforced upon the nation. ${ }^{10}$ In a memorial to the President praying for an impartial statement of the negotiations of the treaty they piteously invoked the "God of truth to tear away every disguise and concealment from their case, the God of justice to guide the President's determination, and the God of mercy to stay the hand of their brothers uplifted for their destruction."11 A copy of this memorial and the resolutions transmitted to the Secretary of War by General Wool so enraged President Jackson that he expressed his surprise that an officer in the army should have received or transmitted a paper so disrespectful to the Executive, the Senate and the Amercian people; declared his settled determination that the treaty should be carried out without modification and with all consistent dispatch, and directed that, after a copy of the letter should have been transmitted to Ross, no further communication by mouth or writing should be held with him concerning the treaty. It was further directed that no council should be permitted to assemble to discuss the treaty. ${ }^{12}$ The

${ }^{8}$ Cherokee Mss. Collection, Tahlequah, Okla.

- Letter of John Ross in Cherokee Mss. Collection.

${ }^{10}$ Cong. Doc. 315, No. 120, p. 798. Payne Mss. 5, Gen. Order, No. 74.

${ }^{11}$ Cong. Doc. 315, No. 120, p. 807.

${ }^{12}$ Ibid, pp. 186, 190. Report of Indian Commissioner, 1836, p. 285. 
President was determined that the treaty he had secured with so much difficulty should not miscarry in its execution.

But the Cherokees, far from convinced, kept up a vigorous campaign against the so-called treaty. In order to enlist the help of their western brethren and unite the efforts of the two nations, the Council of this year had appointed a delegation, of which Mr. Ross was a member, to visit the western nation. The United States agents had no intimation of this action until the delegation had already set out for the west. Major Curry, furious at being outwitted, communicated with the commissioner of Indian affairs who promptly sent strict orders to Fort Gibson to have the principal chief arrested if he should appear there and begin inciting the Indians to oppose the treaty. ${ }^{13}$

Mr. Ross, with rare tact and diplomacy, paid a friendly visit to Agent Stokes of the western nation at Bayou Menard and completely disarmed the old man with his amiable, quiet manner, ${ }^{14}$ won over the chief, John Jolly, succeeded in gaining the promise of the western nation to oppose the treaty and secured the appointment of a delegation to Washington to protest against it. This done, he and his party quietly departed and reached home, having eluded and outwitted the United States authorities, much to their anger and chagrin. ${ }^{15}$

Having secured the coöperation of the western nation a delegation went on to Washington to see what effect their combined forces might have upon the new administration. On March 16 they addressed a communication through Secretary Poinsett to the President asking for a hearing, requesting that their claims might be investigated, that the rightful authorities be dealt with and that the results of the investigation be submitted to the Cherokee Nation. ${ }^{16}$ The Secretary of War replied that the treaty of New Echota had been ratified constitutionally, but that any measures suggested by them would receive candid examination, if not consistent with the treaty. ${ }^{17}$

${ }^{13}$ Cong. Doc. 315 , No. 120, p. 774; also, 685.

${ }^{14}$ Ibid.

15 This was in January, 1837.

${ }^{16}$ Cong. Doc. 315, No. 99, pp. 18-25.

${ }^{17}$ Ibid, p. 24. 
President Van Buren granted Mr. Ross and the delegation an interview at which he treated them politely, even cordially, but told them frankly that nothing could be done to alter or amend the treaty.

Meanwhile the condition of the Indians had been growing steadily worse. General Wool describes the whole scene in the Cherokee country as heartrending and such a one as he would be glad to get rid of as soon as circumstances would permit. The white men were hovering like vultures watching to pounce upon their prey and strip them of everything they had. He predicted that ninety-nine out of every hundred would go penniless to the west. ${ }^{18}$ "I am surprised," he said, "that the Cherokees have not risen in their might and destroyed every resident white man in the country."19 General Dunlap in command of the East Tennessee troops called out to quell the rumored insurrection in 1836, soon found that the Indians, not the whites, needed protection, in furnishing them which he excited the hatred of the lawless rabble of Georgia who, he declared, had long played the part of petty tyrants. He finally decided he would never dishonor the Tennessee arms in a servile service by aiding in carrying into execution at the point of a bayonet a treaty made by a lean minority against the will and authority of the Cherokee people, and disbanding his brigade he went home in disgust. ${ }^{20}$

Even the members of the Treaty party to whom the government was deeply indebted did not go scatheless. Returning from Washington after the final arrangements of the treaty had been completed they found their plantations taken and suits instituted against them for back rents on their own farms. They were in danger day and night from the rabble who flogged Indian men, women and children with hickories and clubs, even constables and justices of the peace being concerned in the mistreatment. Major Ridge in a letter to the President declared that unless given protection by the United States the Indians would carry nothing with them to their new

${ }^{18}$ Ibid, p. 648.

${ }^{10}$ Ibid, p. 82.

${ }^{20}$ National Intelligencer, May 24, 1838. 
homes but the scars of the lash on their backs. ${ }^{21}$ Through all their afflictions and tribulations, however, the Indians remained so consistently opposed to emigration that not one of them who attended the meeting called by General Wool in January, 1837, would receive rations or clothing from the United States for fear they might compromise themselves, preferring to live upon the roots and the sap of trees. Thousands of them had no other food for weeks.

John Mason, who was sent in July, 183\%, as a confidential agent of the War Department to investigate conditions among the Indians, was convinced that opposition to the treaty was unanimous, irreconcilable and sincere. The Cherokees claimed that they did not make the treaty and it could not bind them; that it was made by a few unauthorized individuals and the nation was not a party to it. With all his influence with them, and Mason believed that the mass of the nation, especially the mountain Indians, would stand or fall with their chief, ${ }^{22}$ Ross could not stem the tide of sentiment against removal. If he had advised the Cherokees at this time to acknowledge the treaty he would have forfeited their confidence and probably his life. ${ }^{23}$ His influence was constantly exerted to preserve peace, the reports of his enemies to the contrary notwithstanding. Opposition to the treaty was sincere and sprang from a love of country and was not a political game played by Ross to maintain his ascendency in the tribe. When Colonel Lindsay who succeeded General Wool ${ }^{24}$ was given authority in the summer of 1837 to arrest Ross and turn him over to the civil authorities if he did anything further to encourage the Cherokees in their hostilities to removal, he sought in vain for some excuse to carry out his instructions.

Regardless of threats a council was called for July 31 to which Mr. Mason was dispatched with instructions to traverse and correct any misstatements that might be made by John Ross

${ }^{21}$ Cong. Doc. 315, No. 120, p. 607.

${ }^{2}$ The Treaty party had already gone west with the exception of those who had remained to assist the Government in carrying out the treaty. National Intelligencer, May 24, 1838.

${ }^{23}$ Cong. Doc. 325, No. 82, pp. 3-5.

${ }^{24}$ May, 1837. 
and his followers, ${ }^{25}$ and, if need be, prohibit the assembling of the Council.

Mr. Ross met these trying situations with a quiet dignity of manner, a strength of purpose and a clearness of brain that could not but inspire with confidence the minds of the harassed multitude of Indians who came to rely upon him with a respect and affection akin to reverence. At his humble home in Tennessee he dispensed hospitality to high and low without discrimination, and to the poor full-bloods who were reduced to desperate straits he was not only a chief, but a brother in adversity.

To the white men whose plans and schemes he had so often thwarted, Ross appeared in an entirely different guise. Major Curry regarded him with hatred beyond expression and treated him with a contempt that would have been unendurable to one of less self-control. The agent's attempts, through dark and devious courses, to alienate the Indians from their leader were notorious and his methods of dealing with the aborigines, without the shadow of honor. No one was more cordially hated and thoroughly feared by them. Peyton of Tennessee denounced him and Schermerhorn in the House in 1836 as "the two worst agents that could have been selected in all God's creation.",26 His death in December, 1836, caused a sense of relief throughout the Cherokee Nation. It was the opinion of General Wool that if he had lived long enough he would have been killed by the Indians. ${ }^{27}$ Nathan Smith who succeeded him was a man of honor and integrity who finally overcame much of the prejudice which he at first entertained towards Mr. Ross.

With Governor Lumpkin it was a different story. He naturally had no love for the Indians who encumbered the soil of Georgia, saw no good in them and believed that the only good Indian was the dead Indian. All his racial antipathy seems to have become concentrated against Mr. Ross, whose character he assailed, whose motives he misrepresented and whose acts and conduct he distorted for the purpose of dis-

${ }^{25}$ Cong. Doc. 325, No. 99, pp. 26-32.

${ }^{26}$ Congressional Globe, 24th Congress, p. 477.

${ }^{27}$ Gen. Wool to Sec. of War, June 3, 1837. Cong. Doc. 315, No. 120. 
countenancing him before the Federal Government. He refused to recognize his chieftainship and urged the government to do so, not on the ground of justice, but of policy, acknowledging that if Ross and his party were recognized the validity of the treaty could be called in question. ${ }^{28}$ He even went so far as to say that Mr. Ross ought to be "put in strings and banished from the country; that although a large slaveholder he was well qualified to fill a prominent place amongst the New England abolitionists or in the Republic of Hayti," and that to one of these places he wished to see him emigrate. He considered Ross the soul and spirit of the whole opposition. To the Georgian this Scotch Indian was a "subtle and sagacious man" who, under the guise of an unassuming deportment, concealed an unsurpassed arrogance and by his dignified, reserved manner "acquired credit for talents and wisdom which he never possessed."29

Fearing some change of Indian policy from the Van Buren administration, Mr. Lumpkin hastened to redouble his energies in fortifying the mind of the new executive against the stratagems of the wily chief. Writing the Secretary of War in the summer of 1837 he warned him that Mr. Ross was the master spirit of opposition to the execution of the treaty on whose movements he would keep a watchful eye so far as circumstances would allow. For he was a reserved, obscure and wary politician. ${ }^{30}$ It is not strange therefore that the President became more and more reluctant to hold intercourse with Mr. Ross and his party.

Pressure for removal under the supervision of Mr. Lump$\mathrm{kin}^{31}$ became more constant and uniform, but when the end of the year approached without any indication of an intention on the part of the Indians to go west, the United States commissioners and agents issued a proclamation ${ }^{32}$ stating that according to the treaty they now had only five months in

${ }^{28}$ Cong. Doc. 325, No. 82, p. 10.

${ }^{20}$ Lumpkin, Removal of the Cherokees, pp. 229, 230.

${ }^{30}$ Cong. Doc. 325, No. 82, p. 11.

${ }^{21}$ Mr. Lumpkin entered the Senate in Dec., 1837, and from that vantage point wielded the fatal blows to the last lingering hopes of the Cherokees.

${ }^{2}$ Dec. 28, 1838. 
which to remove, and they were not to be deceived by the hope that a longer time would be given them. The treaty, it declared, would be executed without change or alteration and another day beyond the time named ${ }^{33}$ would not be allowed to them. They were warned to rely no longer upon John Ross and his friends who had been misleading them and subjecting them to pecuniary losses. The executive had declined all further intercourse with Mr. Ross and an end had been put to all negotiations upon the subject. ${ }^{34}$ To which the Cherokee delegation then in Washington replied in a memorial that the New Echota treaty was an outrage on the primary rules of national intercourse, as well as of the known laws and usages of the Cherokee Nation and was therefore destitute of any binding force upon them.

"For adhering to the principles on which your great empire is founded, and which has advanced to its present elevation and glory, are we to be despoiled of all we hold dear on earth?" they asked. "Are we to be hunted through the mountains like wild beasts and our women and our children, our aged, our sick, to be dragged from their homes like culprits and packed on board loathsome boats, for transportation to a sickly clime?"35

Cherokee removal and the New Echota treaty called forth strong remonstrance from some of the greatest statesmen of the country who denounced the policy of the administration in vigorous terms. Webster and Everett of Massachusetts, Frelinghuysen of New Jersey, Sprague of Maine, Storrs of New York, Crockett of Tennessee and Clay of Kentucky protested strongly against it. It became almost a party question, the Democrats supporting Jackson, the Whigs condemning him. Henry Clay considered that the chief magistrate had inflicted a deep wound on the American people. ${ }^{36}$ Webster remarked in the Senate in May, 1838, that there was a growing feeling that great wrong had been done the Cherokees by the treaty of New

${ }^{2 s}$ May 23.

4 Cong. Doc. 329, No. 316, p. 5.

${ }^{85}$ Ibid, pp. 1-4.

${ }^{\infty}$ Cong. Doc. 315, 120. Letter of Henry Clay to John Gunter, Sept. 30, 1836. 
Echota. "Speeches in Congress," says Benton, "were characterized by a depth and bitterness of feeling such as have never been excelled on the slavery question." ${ }^{38}$ Calhoun of Tennessee did not regard the New Echota treaty as a binding contract at all since only about twenty out of eighteen thousand assented to it. ${ }^{39}$ Wise declared that it was not a bona fide treaty. The Cherokee Nation had never agreed to it and now almost unanimously protested against it. The whole proceedings in relation to the negotiations he declared a fraud upon the Indians. ${ }^{40}$ Schermerhorn he stigmatized as a "raw head and bloody bones" to the ignorant Indians while their chiefs were at Washington and he had made what he called a treaty with a very small portion of the Cherokees. Henry A. Wise with eloquent words in a speech in the House paid high tribute to John Ross as the man who had swam the river at the battle of the Horse Shoe and, at the risk of his life, had brought away the canoes which enabled the Jackson forces to gain the victory over the Creeks. "And now he is turned out of his dwelling by a Georgia Guard and his property all given over to others. This is the faith of a Christian nation. John Ross is known by many members of the House to be an honest, intelligent man worthy to sit in the councils of the nation, let alone the councils of an Indian tribe." 41 His objection to the treaty, Wise considered an honest one, and declared that Ross, the Indian chief from Georgia, would at any time compare favorably in intellect and moral honesty with Forsythe, a member of Van Buren's cabinet, from the same state. ${ }^{42}$

A memorial of the Cherokee delegation in the winter of 1838 was laid on the table in the Senate by a vote of 36 to 16 , and others from citizens of New York, Pennsylvania, Massachusetts and New Jersey requesting an inquiry into the validity of the New Echota treaty met a similar fate in the House. Discussions of these memorials brought out expressions of sympathy for the Indians and admiration for their principal chief but took no practical form for their relief.

${ }^{37}$ Cong. Globe, 2nd session, 25th Congress, p. 404.

${ }^{a 8}$ Benton's Thirty Years' View, Vol. I, p. 625.

${ }^{\circledR 0}$ Cong. Globe, 24th Congress, p. 477.

${ }^{40}$ Ibid.

«1 Cong. Globe, 25th Congress, p. 68.

2 Ibid. 


\section{CHAPTER XIII}

\section{Compulsory Removal}

Through the winter and spring of 1838 Mr. Ross continued protesting against the validity of the treaty, remonstrating against its execution and seeking to secure a more favorable one made with the legally constituted authorities of the Cherokees. "We will not recognize the forgery palmed off upon the world as a treaty by a knot of unauthorized individuals", he declared, "nor stir one step with reference to that false paper". 1 And yet, although it was the wish of the Cherokees to remain on "the soil of their ancestors inherited from the common Father of us all", they were at length, under the necessity of circumstances, ready to go west if the Federal Government would pay them for their land far less than it asked for the wildest of its own. Removal by compulsion, he pointed out, would prove more expensive than a new treaty, and, aside from the question of the faith of treaties, the Federal Government could well afford to do itself and the Indians the justice for which they were pleading. He was supported in his appeals by memorials and petitions from various parts of the country, particularly from Pennsylvania and Massachusetts, praying for a repeal of the Schermerhorn treaty on the ground that it did not represent the will of the majority of the Cherokee people.

The friends of removal in general and Mr. Lumpkin in particular, always keenly alert and ou the defensive where the Indian question was concerned, met these protests and petitions with arguments astonishingly naive, to say the least, when compared with the logical and convincing reasoning advanced by Chief Ross and the memorialists. The idea of submitting a treaty to an Indian people to be decided upon "the broadest basis of democracy" was scoffed at by the Senator who maintained that "it ought to be sufficient to satisfy the wise and good everywhere that the treaty was negotiated on behalf of

${ }^{1}$ Letter of John Ross to Penn. House of Rep., May, 1838. Cher. Mss. Records, Tahlequah, Okla. 
the Cherokees by the most enlightened and patriotic Indian men who ever negotiated a treaty, and that it secured to the whole people more signal advantages than were ever before secured to an Indian people by treaty entered into with this Government". As evidences of the superior advantages to be gained by removal he read to the Senate ${ }^{3}$ a letter from John Ridge, who had already located in the west, picturing in the most alluring terms the beauties of the western nation, the richness of the soil, the healthfulness of the climate and all the other natural advantages which in his judgment far surpassed those of the Eastern Country. Why the Cherokees refused to emigrate to a land where such superior opportunities and advantages awaited them was beyond the comprehension of the Senator from Georgia and he was of the opinion that people of such poor discrimination should be treated "as minors and orphans and other persons who are incompetent to take charge of their own rights". ${ }^{4}$

Unfortunately for the Cherokees, Mr. Lumpkin was more proficient in political manipulation than strong in logical consistency, and so alert were he and his supporters, and so strong their determination to carry out their Indian policy that all the efforts of Ross and his friends in Washington to secure the abrogation of the treaty were circumvented and blocked at every point, while May was fast approaching and the time drawing near for removing Indian encumbrance from the soil of the sovereign states of Georgia, Alabama and Tennessee.

As for the mass of the Cherokee people, two years of threats and promises had failed to bring them to admit the validity of the treaty, or to show any inclination to emigrate of their own accord. The failure of their delegation to secure the repeal of the treaty did not weaken their determination to stand for their rights. Even the threats of fresh troops sent into the country to put down opposition failed to terrify them into submission or frighten them into abandoning such haunts as had been spared them on account of the nature of the country,

${ }^{2}$ Lumpkin, Removal of the Cherokees, p. 208.

${ }^{8}$ May 15. Ibid, p. 201; National Intelligencer, May 24, 1835.

'Lumpkin, Removal of the Cherokees, p. 198. 
and to which they stubbornly clung, unsubdued yet unresisting.

When it had become perfectly evident that removal could be accomplished only by sheer brute force, protests from the country at large became so vehement that the administration began to look for a way to satisfy public sentiment without antagonizing the states concerned. As a result the President, early in May, proposed as a compromise to extend the time of removal two years. ${ }^{5}$ This suggestion promptly met with such strong opposition from Governor Gilmer that Mr. Van Buren, the diplomatic, had to back out of this position as gracefully as he might and allow the treaty to take its course. ${ }^{6}$

As a result of pressure brought to bear by executive machinery between the adoption of the New Echota treaty and January, 1838, about two thousand Cherokees had emigrated. Something more than thirteen thousand remained in the Cherokee Nation East, in the spring of 1838. The President, convinced that they would not remove without compulsion, dispatched General Winfield Scott to the Cherokee country - to take command of the troops already there and to collect an additional force comprising a regiment each of artillery and infantry and six companies of volunteers, a sufficient force, unquestionably, to overawe the disarmed and starving natives and compel submission..$^{7}$ In case he found it necessary, however, the military commander was authorized to call upon the governors of the neighboring states for voluntary militia.

General Scott took up his headquarters at New Echota, the former capital of the nation, whence he issued a proclamation announcing that the President had sent him with a powerful army to cause the Cherokees, in obedience to the treaty of 1835, to join their brethren beyond the Mississippi, and before another moon had passed every man, woman and child must be on the way to the west. ${ }^{8}$

In order to carry out his instructions to remove the Indians at all hazards he began enrolling and collecting them at such

${ }^{5}$ Cong. Doc. 330, No. 421, pp. 2, 17.

Ibid, p. 4.

There were as many soldiers as adult Indians. Payne Mss. 6, pp. 13-38.

${ }^{8}$ Cong. Doc. 329, No. 316, p. 7. 
a rate and in such a manner as to work the greatest hardship upon them. Stockade forts were built at convenient places and squads of soldiers were sent into the surrounding country with guns, bayonets, swords and pistols to search every cave and hillside for the natives who were driven at the point of the bayonet and the muzzle of the musket into one of the camps. Accounts are given of such revolting deeds of cruelty and inhumanity perpetrated upon the helpless victims as seem impossible to have occurred in a civilized nation.

Mr. Mooney, after having talked with some of the Cherokees who had gone through the "Reign of Terror", gives this vivid account of it: "Families at dinner were startled by the sudden gleam of bayonets in the doorway and rose up to be driven with blows and oaths along the weary miles of trail that led to the stockade. Men were seized in their fields, or going along the road, women were taken from their wheels and children from their play. In many cases on turning for one last look as they crossed the ridge they saw their homes in flames fired by the lawless rabble that followed on the heels of the soldiers to loot and pillage. So keen were the outlaws on the scent that, in some instances, they were driving off the cattle and other stock of the Indians almost before the soldiers had started the owners in the opposite direction", 9 and ghouls were searching Indian graves for the silver pendants and other valuables deposited with the dead.

In order to take the Indians completely by surprise and prevent all possibility of escape the soldiers were ordered to approach and surround the houses as noiselessly as possible. One aged full-blood, finding himself so surrounded, calmly called his household of children and grandchildren about him and kneeling prayed with them in their own language, the soldiers standing by in shamefaced astonishment. Rising from their devotions they were warned by the soldiers to make no needless preparations but to be off at once, and were hurried away each one carrying such necessary belongings or cherished possessions as he could quickly lay hands on, even the little children grasping in their hands or hugging to their hearts some childish

'Mooney, Myths of the Cherokees, p. 130. 
treasure-a bow and arrows, a blow gun, a string of beads or perhaps a battered rag baby. Those who attempted to escape were shot down like criminals. The story is told of a deaf boy who upon seeing the soldiers coming was panic stricken and started to run away. When he failed to respond to the order to halt, a musket was leveled at him and he fell lifeless to the ground. ${ }^{10}$

Those who were utterly unable to travel, the helpless aged and the mortally ill, were left in remote cabins to die of starvation and neglect. Children were separated from parents who, in some cases, never saw them again nor knew what fate befell them. A few women and children, warned of the coming of the soldiers, fled to inaccessible mountain fastnesses and hid in caves to perish of starvation, while the men were hunted and trapped like wild beasts.

Old men, delicate women and little children were driven like cattle $^{11}$ until strength failed them and they fell fainting by the roadside. When brutal kicks and saber thrusts could not rouse them to further effort they were loaded into wagons and hauled over rough mountain roads to the stockades; or, where wagons were wanting, left to recover or die as they might, while friends and family, pricked on by the bayonet, were not permitted to minister to their necessity. ${ }^{12}$

At night sick and well were forced to lie upon the bare ground in the open with no protection from the weather and herd together for warmth, like hogs. Not infrequently death relieved them from their suffering before the journey was completed. In that case the soldiers were considered quite humane who stopped long enough to dig for a grave a shallow trench by the roadside and fling a few shovelfulls of earth over the lifeless body.

Submission was the rule among the Indians, but there were occasional exceptions as in the case of Tsâli, or Charley, an old man who, with his wife, a brother and three sons, two of whom

${ }^{10}$ Payne Mss. 9, pp. 23-25.

${ }^{11}$ The same language was used in driving them as is commonly used in driving cattle and hogs.

${ }_{12}$ Payne Mss. 9, pp. 23-25. 
had families, while the third was a mere lad, were surrounded, taken captive by the soldiers, and men, women and children were started on foot to one of the stockades. 'Tsâli's wife, a frail and delicate woman, unable to keep up with the others, was prodded on like a brute by the bayonets of the soldiers. The old man, goaded to desperation by the sight of this brutality and his wife's suffering, suggested to the others that they make a dash for liberty. As the conversation was carried on in Cherokee the soldiers did not understand it and when each warrior suddenly leaped upon the nearest white man the surprise was so complete that one soldier was killed while the rest fled in confusion. The Indians escaped to the mountains where they were joined by numbers of their tribesmen who had either escaped from the stockades or had succeeded in eluding the soldiers.

Among them was an Indian named Euchela, who with a band of a hundred followers, belonged to the class of outlaws. Having failed in every attempt to take the fugitives by force, General Scott determined to try reconciliation with a part of them. Colonel W. H. Thomas, a trader well known to the Indians, was chosen to make overtures to Euchela and his warriors, promising that, if they would surrender Tsâli and his family, they would be permitted to remain in Carolina and "be at peace" until their case could be adjusted by the Federal Government. "I cannot be at peace", Euchela declared, "because it is now a whole year that your soldiers have hunted me like a wild deer. I have suffered more than I can bear. I had a wife and a little child, a bright eyed boy, and because I would not become your slave they were left to starve upon the mountains and I buried them with my own hands at midnight". ${ }^{13}$ Finally, however, he was induced to accept the overtures of General Scott, and summoning his warriors with a whoop he laid the proposition before them. After much hesitation they, too, were prevailed upon to agree to the offer.

Tsâli, hearing of this compromise and knowing that his fate was sealed, came in voluntarily with his brother and his two eldest sons and surrendered. They were tried by court-

${ }^{13}$ Lanman, Letters of the Allegheny Mountains, p. 110. 
martial and sentenced to be shot. Bound to the tree where he was to be executed the old man asked to be permitted to speak and the request was granted. "I am not afraid to die," he is reported to have said, "O no, I want to die, for my heart is very heavy, heavier than lead." Turning to Euchela he continued, "But, Euchela, there is one favor I wish to ask at your hands. You know I have a little boy who was lost among the mountains. I want you to find that boy if he is not dead and tell him that the last words of his father were that he must never go beyond the Father of Waters, but die in the land of his birth. It is sweet to die in one's native land and be buried by the margin of one's native streams."14 When he had finished speaking the bandages were placed over his eyes and the execution proceeded. Some delay having occurred in the arrangement, he uncovered his eyes to see a dozen of his tribesmen in the very act of firing. Calmly and deliberately he replaced the cloth and the next moment was writhing in his lifeblood. General Scott had commanded that a dozen Cherokee prisoners be compelled to do the shooting in order to impress upon the Indians the helplessness of their situation. Tsâli's youngest son, Wasitûna, was finally pardoned because of his youth and allowed to remain in North Carolina, thus fulfilling his father's wish that he might die in the land of his birth. ${ }^{15}$

Colonel Z. A. Ziles, of the Georgia Militia, who was afterwards an officer in the Confederate army, in describing to Mr. Mooney this chapter of Cherokee history in which he himself took part, said, "I fought through the Civil War and have seen men shot to pieces and slaughtered by the thousands but the Cherokee removal was the cruelest work I ever knew."16

Conditions in the stockades were in keeping with the whole policy of forcible eviction. Musty corn meal and fat salt pork or rank bacon were the only food furnished by removal officers who had let the contracts for furnishing subsistence at war prices. This was the time of year, too, when the natives were

${ }^{14}$ Lanman's Letters of the Allegheny Mountains, p. 113.

${ }^{15}$ Ibid.

${ }^{16}$ Mooney, Myths of the Cherokees, p. 131. 
accustomed to fresh fruits and vegetables in abundance. Women pleaded in vain for permission to go out and hunt for wild berries, onions and greens for their families. There was no milk even for the little children. Old and young, sick and well, were compelled to eat the corn hoe cake and the fried bacon or perish of starvation.

The medical aid was hopelessly, even criminally, inadequate and incompetent. One of the doctors proved to be a dentist who drew his salary regularly, but an Indian molar, never. Dentists were superfluous among the Cherokees at this time. It was good sound medical attention the prisoners needed but failed to get. After several sudden deaths had occurred, the suspicion was aroused that the doctors were poisoning them and they refused to take the medicine. ${ }^{17}$ The herbs, whose medicinal properties they had known from time immemorial and which they would have gathered and brewed so eagerly, were denied them. No provision was made for sanitation and the camps were soon filthy and swarming with vermin. Fever and dysentery were rampant and infant mortality during the summer months was appalling. Add to these conditions the facts that whiskey was allowed to be brought into the camps and sold freely to the military, and that drunken soldiers had no regard for the sanctity of Cherokee womanhood when it was at their mercy, and the picture of the last extremity to which the captives could be reduced is complete.

The stockades were so strongly guarded that escape from them was most difficult indeed, while leave of absence was denied to everyone on general principles. A few captives, however, succeeded in eluding the pickets and escaping, some to go in search of lost members of their families, and others to look after the old and sick who had been left behind. The Georgia Guard promptly captured part of them, gave them a hundred lashes on the bare back in punishment of their crime and then returned them to the stockade with dire threats of what would happen should the offense be repeated.

When a sufficient number had been gathered into the stockades the work of removal began. Early in June several parties

${ }^{17}$ Payne Mss. 9, pp. 23-25. 
aggregating about five hundred were brought down to the old agency on the Hiwassee River, ${ }^{18}$ to Ross's Landing ${ }^{19}$ and to Gunter's Landing. ${ }^{20}$ Here they were forced into filthy and unsafe boats and sent down the river. In one instance so many were crowded into an unseaworthy steamer as to cause it to threaten to sink. The surplus was thereupon hastily and indiscriminately unloaded, separating children from parents, husbands from wives, who were not to be reunited until months afterwards when they met in the west. ${ }^{21}$ These boats were sent down the Tennessee to Mussel Shoals where a transfer was made and the journey continued to Little Rock, and a second landing made. There in the heat of summer the emigrants were compelled to await the convenience of removal officers, sometimes for weeks, before they could proceed to Indian Territory. Much sickness and many deaths resulted from the long and wearisome voyage in the sickly season of the year.

From first to last the forcible removal of the Cherokees was strangely bungled. Contracts had been let to incompetent officials who neglected to provide adequate means of transportation, particularly wagons for the land route, and a sufficient supply of provisions; they also failed to establish depots of supplies along the way, a very important oversight when it is remembered that much of the country through which they were to pass was thinly populated and in the frontier stage at this time.

To complicate matters still further a drought had set in during May and lasted until October, which rendered transportation by land well nigh impossible, as it was estimated that for many marches in succession it would have been impossible for a company of a hundred to find even a scanty supply of water. $^{22}$ Up to June a scarcity of boats also had made it impossible to send off a considerable proportion of the captives by water. By this time the Hiwassee and the Tennessee had

${ }^{18}$ Now Calhoun, Tenn.

${ }^{10}$ Chattanooga, Tenn.

${ }^{20}$ Guntersville, Alabama.

${ }^{21}$ Payne Mss. 9, pp. 23-25.

${ }^{22}$ Cong. Doc. 429, No. 288, p. 36. 
almost ceased to be navigable and were rapidly falling. It was also known that the Arkansas was very low.

In this state of affairs, on July 23, the Cherokee Council proposed to General Scott that the whole business of emigrating be taken over by the nation. The condition of the people, they reasoned, was such that all dispute as to the time of emigration was set at rest and, since they were under the absolute control of the commanding general, all inducements to prolong their stay in the Cherokee Nation East were taken away, and, however strong their attachment to the home of their fathers might be, their interests and wishes now were to depart as early as might be consistent with safety. ${ }^{23}$ General Scott granted the request on condition that the Council be held responsible for the good behavior of the Indians in the camp and on the march and that the first detachment should have started by the first of September, the last not later than October 20. The Council was to take entire control of all departments, provide all necessary means of travel and subsistence and employ all assistance in transportation. The sum of sixty dollars a head was allowed for the expense of moving every man, woman and child.

The situation of the captives improved immediately. The military was removed, the Georgia Guards forced to retire and the quack doctors dismissed. The people, permitted to scatter out freely and find as good locations for camps as a rather limited area permitted, found their condition much more endurable than it had been under martial law. They naturally regarded as a godsend the change in arrangement for removal, for they felt that their interests would now be safeguarded by their chiefs and councilors who had stood by them through the severest temptations and refused to betray them for fear or favor.

That the principal chief did not regard this confidence of his people as an asset to be traded on for his own profit, but as a reward well earned by conscientious devotion to what he considered their interests, and as something to be appreciated and cherished by him, is evident from a letter written to a friend

${ }^{23}$ Ibid, p. 405; Ibid 338, No. 459, p. 1. 
in the spring of 1838: "If my people did not know that where their interest has been involved I should have thought it dishonorable to regard my own; if they did not also know that I have never deceived them and that I never will desert their cause under any circumstancs of temptation or calumny to myself or difficulty or danger to them; if they did not know all this I should not so long have possessed the confidence with which they have honored me and which I prize more than all wealth or praise." ${ }^{24}$ The Federal Government, after two years in which it had refused to recognize Mr. Ross's official position, after it had added insult to insult and injury to injury, had, at last and after all, been glad to turn to him for escape from the embarrassing and well nigh hopeless situation of the summer of 1838.

The Creeks and Seminoles, Choctaws and Chickasaws forced by the treachery of their leaders and the iron will of President Jackson had already gone west and were now adjusting themselves as best they could to their new environment in the wilderness inhabited by wild animals and wilder men. ${ }^{25}$ The Cherokees with their more advanced civilization and more patriotic leaders had been able to resist longer, but had paid a heavier price; the disorganization of tribal government and customs, the wreck of homes and fortunes, the estrangement of friends and kinsmen, moral degradation, physical suffering and loss of life unparalleled at that time in the history of any tribe, constitute part of the penalty for Indian patriotism and loyalty to principle. All this at the hands of a government established less than three-quarters of a century before upon the principle of justice and the rights of man. This same government had shot down Cherokees like dogs, quartered them like malefactors and even put a price upon their heads. And the end was not yet.

${ }^{24}$ John Ross to Pennsylvania Legislature. Cherokee Mss. Records.

${ }^{25}$ Irving's Tour of the Prairies, pp. 8-12. 


\section{CHAPTER XIV}

\section{The Trail of Tears}

Left to themselves, the Cherokees set about systematizing their forces and bringing order out of chaos in a logical and businesslike manner. By resolution of their Council they made Chief Ross superintendent agent of emigration and entrusted the entire management of removal to a committee ${ }^{1}$ of their own people. This committee organized the people along the line of family ties, and of kinship where possible, into thirteen detachments comprised of as nearly equal numbers as practicable. Over each detachment were placed as officers two such men as were best qualified to manage that particular group of people. After a thorough investigation had been made of the different routes each division was to proceed over the one selected by its leaders. ${ }^{2}$

Late in August the Council and people assembling for a final meeting at Aquohe Camp, about two miles south of the Hiwassee River, passed a resolution declaring that, never having consented to the sale of their country either themselves or through their representatives, the original ownership still rested in the Cherokee Nation whose title to the lands described by the boundaries of 1819 was still unimpaired and absolute; that the United States was responsible for all losses and damages in enforcing the pretended treaty; as they had never relinquished their national sovereignty therefore the moral and political relations existing among the citizens towards each other and towards the body politic could not be changed by their forcible expulsion; finally they pronounced their laws and constitution in full force to remain so until the general welfare rendered a modification expedient. ${ }^{3}$ This action bound anew the people, distracted and confused by the harrowing experiences of the last few months, into a united body politic which went, not as individuals but as a nation, into exile.

${ }^{1}$ The committee was composed of John Ross, Richard Taylor, Samuel Gunter, Edward Gunter, James Brown, Elijah Hicks and Sitewakee.

${ }^{2}$ Cong. Doc. 338, No. 459.

${ }^{3}$ Payne Mss. 6, p. 6. 
As September approached every exertion was made by both leaders and people to meet their obligations to the United States and keep their promise to General Wool that the first detachment should be under way September 1. Notwithstanding the continuance of the drought and the great amount of sickness among them it was determined that a company should be ready to start on the last day of August from the camp about twelve miles south of the agency in Tennessee. ${ }^{4}$ It was the plan to get a part of the company in motion on the twenty-eighth, the remainder to follow the next day and come up while they were crossing the Tennessee river about twenty-five miles distant. At noon everything was in readiness for starting. Wagons and teams were stretched in a line along the road through the heavy forest. Groups of persons were gathered around the wagons or lingered about some sick friend or relative who was to be left behind. The temporary shacks covered with rough boards of bark which had been their shelter during the past weeks had been converted into bonfires, and were crackling and falling into glowing heaps of embers here and there on the camp ground. The day was bright and beautiful; not a cloud dimmed the blue above. But a gloomy thoughtfulness shadowed the faces of the people. "In all the bustle of preparation there was a silence and stillness of voice which betrayed the sadness of heart."5 When at last the signal was given to start, Going Snake, a white haired chief of four score years, mounted on his faithful pony, took the place at the head of the column followed by a cavalcade of younger men. Just as the procession was on the point of being set in motion a clap of thunder smote the stillness and a dark spiral cloud was seen rising above the western horizon. Peal after peal rent the air and reverberated among the mountain peaks like the voice of some mighty offended deity, while overhead the sun still shone in an unclouded sky. Not a drop of rain fell. The cloud presently disappeared and the thunder died away in the distance, but the scene was not one to be easily forgotten by the superstitious Indians, always keenly alive to natural phenomena to which

${ }^{4}$ Calhoun.

${ }^{5}$ W. Shorey Coody to John Howard Payne. Payne Mss. 6. 
they often attached supernatural significance. Was it the voice of divine indignation against the wrongs already suffered or the warning of some greater calamity awaiting them in the future? $?^{6}$

In consequence of sickness which still prevailed in the camps and the drought which rendered travel distressing beyond description General Scott called a halt and ordered emigration suspended for several weeks. ${ }^{7}$ It was not until some weeks later that the last detachment was ready to set out for the west. This party under the personal direction of the principal chief, himself, left Rattlesnake Springs, near Charleston, Tennessee, October 31. Crossing to the north side of the Hiwassee at a ferry above Gunstocken Creek they continued down along the river. The sick, the old people and children rode in the wagons ${ }^{8}$ which carried the provisions, bedding, cooking utensils and such other household goods as they happened to have. The rest proceeded on foot or horseback. Now and then might be seen a carriage, a survival of more prosperous times. One of these carried the chief's family while he, mounted on horseback, rode along the line directing operations and encouraging the people. The march was conducted with the order of an army; a detachment of officers heading the procession was followed by the wagons while the horsemen and those on foot brought up the rear, or when the road permitted, flanked the procession. Crossing the Tennessee river near the mouth of the Hiwassee ${ }^{9}$ the procession passed through Tennessee by way of McMinnville and Nashville and thence through Kentucky to Hopkinsville where a halt was made to bury Whitepath $^{10}$ who had fallen a victim to illness and exposure. There

- Mr. Coody was one of the officers engaged in removing this detachment. The story is taken almost verbatim from his account of the incident.

'Cong. Doc. 411, No. 1098, pp. 48, 49.

${ }^{8} \mathrm{~A}$ wagon drawn by six horses, and five saddle horses were provided for every twenty persons. The young people and the able bodied were expected to walk. Gen. Scott thought it would be good for their health. There were six hundred and forty-five wagons used for the transportation of the thirteen detachments.

' At Tucker's Ferry. Mooney, Myths of the Cherokees, p. 132.

${ }^{10} \mathrm{He}$ was in charge of a detachment. 
they buried him by the roadside, and built over his grave a wooden box in lieu of a more enduring and fitting monument to his long and loyal service to his people. At the head and foot they placed poles bearing black streamers as a signal to those coming on behind that they might not pass by without noting the last resting place of their venerable chief. Moving on, they crossed the Ohio, near the mouth of the Cumberland and thence passed through southern Illinois to Cape Girardeau.

A severe winter had set in before the last detachment reached the Mississippi. The river was choked with floating ice, crossing was dangerous, and they were compelled to await the clearing of the current. The weather was bitterly cold and hundreds of sick and dying filled the wagons or were stretched upon the frozen ground with only a sheet or blanket stretched above to protect them from the cutting blast. The hardships through which they had passed during the last few months had reduced their vitality, while homesickness and mental depression so preyed upon their minds as to render them easy subjects to disease from which they could not rally. Hundreds never lived to cross the Father of Waters, and their bodies were left to moulder in an alien soil and among a people with scant regard for the sanctity of an Indian grave.

When finally the last detachment was able to cross the river and continue the journey they found it necessary to take the northern route through central Missouri by way of Springfield and Southwest City, because those who had preceded them going through the southern part of the state to Fort Smith had killed off the game upon which they depended largely for subsistence. It was March when they reached their destination. More than four thousand had perished on the way, among them the wife of Chief Ross. For many years the road the exiles travelled on this fateful journey was known to the Indians by a word in their language meaning the "Trail of Tears".

Thus heartbroken, cowed and scorned, the last remnant of this once mighty and fearless tribe had passed from the land they loved, "broad, set between the hills", moving with bowed heads on toward the setting sun. The history of Cherokee wrongs had been so long before the public that it failed, for lack 
of novelty, to arouse fresh sympathy. With a few exceptions the world read the story unmoved. The Indian was after all only

"A savage! Let him bleed and eat his heart and swiftly go;

Our strength's our right. The tale is old! E'en so."

"The pantherfooted, lithesome Indian brave

We thought not worth our while to try to save.

But welcomed hither hordes of king-crushed souls,

The worn out serfs who cringed to lords for doles;

We gave an eagle race the grave as bed;

Our fields yet bear his sign, the arrow head."'11

And yet who knows? Some great poet of humanity in the future may find in the tragic story of the expatriation of these children of the forest the theme for an epic or a drama of surpassing grandeur and pathos which may stir all mankind to pity for their sorrow and admiration for their virtues. If, peradventure, it comes not too late, like tears and flowers for the dead, who in life would have been made happier and better for the sympathetic word we had not sense to say, and the helping hand we had no time to extend, then a recreant nation may awake to the enormity of its injustice and inhumanity towards a valiant aboriginal people, and hasten to make what amends it may to their crushed and decadent descendants crowded back into remote corners of a country where once they were kings and emperors.

${ }^{11}$ Calvin Dill Wilson, The Arrow Head, Memphis Commercial Appeal, May, 1813. 


\section{CHAPTER XV}

\section{A Triple, Tragedy}

The great body of the emigrants, arriving in the west in the winter of 1839, went into camp on a small river called the Illinois ${ }^{1}$ to await the opening up of spring. The purpose of the encampment was twofold. It furnished headquarters and a community of interests for the newicomers until they could look about for suitable locations for homes, so that disbanding and taking up the burden of adjustment and the business of making a living in an unfamiliar economic environment would be attended with fewer hardships than if they had been thrown at once each upon his own resources. It also kept them within reach of the governing body until their political status could be established upon a permanent basis in the new country.

Barely had they pitched their camp, when they found themselves confronted with a situation scarcely less distressing than the one from which they had just escaped. Coming to the west as a nation driven into exile, bearing with them their Lares and Penates, they found themselves not only strangers in a strange land amid surroundings and conditions new and unfamiliar, but among a people with a political organization of their own, who were jealous of their rights and prerogatives, and who naturally looked askance upon so large a number, even of kinsmen, arriving in their midst with claims to all the rights of a sovereign nation. Here, too, they came face to face with the group of men at whose door they laid the blame of their expatriation and the suffering still fresh in the mind of a race which has always boasted of never forgetting a benefit conferred nor an injury inflicted.

There had been two parties in the eastern nation. In the west there were three, the Emigrants or Nationalists, as the followers of Mr. Ross called themselves, the Treaty party and the Old Settlers. The Treaty men, who for reasons of selfpreservation and policy had preceded the Emigrants, took advantage of the situation by promptly making friends with the

${ }^{1}$ In eastern Oklahoma. 
Old Settlers, or Cherokees West, comprising approximately a third of the tribe, and set to work to build a strong party of opposition to Mr. Ross and his friends. The conditions in the western nation at this time were most favorable to the success of the scheme.

Of the early westward migrations and the negotiations which led, in 1817, to the assignment of land in Arkansas to the Cherokees something has already been said. The tract upon which they settled belonged to the Osages whose claim the United States had not taken the trouble to satisfy. So, for more than a decade, the history of the western band is chiefly a story of Osage raids and Cherokee retaliations. Delay in surveying the lines and taking the census and the withholding of annuities until the census should be taken in the hope that the whole tribe might soon be induced to emigrate, all worked great hardship upon the Indians, hindering both civic and economic development. ${ }^{2}$

Meanwhile there was a growing demand on the part of Arkansas to rid her soil of Indian occupancy. When, therefore, a delegation from the Western Council went up to Washington, in the winter of 1828 , to urge the settlement of their claims, such pressure was brought to bear upon them by the War Department as to practically force consent to the exchange of their lands in Arkansas for a tract of seven millions of acres lying farther west, with a perpetual outlet as far west as the sovereignty of the United States might extend. ${ }^{3}$ The treaty was bitterly opposed by the tribe and the delegation on returning home barely escaped with their lives. ${ }^{4}$ The Council pronounced them guilty of fraud and treason and declared the treaty null and void. Before they could do anything to prevent it, however, the treaty had been ratified by Congress and they found protest of no avail. Thus "barely ten years after they had cleared their fields in Arkansas they were forced to aban-

${ }^{2}$ Royce, Cherokee Nation of Indians, pp. 222, 242, 243; Washburn's Reminiscences of the Indians, pp. 112-122; McKenney and Hall, Indian Tribes of North America, II, pp. 125, 6, Vol. I, pp. 251-260.

${ }^{8} U$. S. Statutes at Large, p. 311.

${ }^{4}$ The laws of the Western Cherokees also made it a capital offense to negotiate any sale of land except by authority of the Council. Mooney, Myths of the Cherokees, p. 141; Starr, The Cherokees West, p. 110. 
don their cabins and plantations and move once more into the wilderness". 5

Progress under such disheartening conditions was slow and difficult. And yet considerable advancement was made. Thomas Nuttall, who made a journey up the Arkansas river in 1819, described their farms as "well fenced and stocked with cattle", while the houses were decently furnished, a few of them evenly handsomely and conveniently. ${ }^{6}$ A year later a mission school was built at the Cherokee agency near the mouth of Illinois Creek, by the Reverend Cephas Washburn who did good service for religion and education until the treaty of Washington made removal necessary. The missionaries followed the Cherokees in their exodus from Arkansas and rebuilt their mission of Dwight in the new country at the mouth of the Illinois river. ${ }^{7}$ Here also was located the new capital named in honor of the venerable chief Takattoka.

The civil affairs of the Cherokees West had been continually confused and disturbed, not only by the indifferent policy of the Federal Government, but by the almost constant arrival of emigrants from the old nation. At the head of the tribal government from 1813 to 1818 was Takattoka, an aged chief of the conservative type. Upon the arrival of a considerable delegation under the treaty of 1817 a contest for leadership ensued between him and Tollunteeskee, the chief recognized not only by the emigrants but the United States. The older chief was forced to yield to the newcomers and take second place even after his rival died leaving the chieftainship to John Jolly, a descendant of Tollunteeskee. ${ }^{8}$

In a reorganization of the government a few years later ${ }^{9}$ a plan was adopted similar to the one in use in the east at this time. They had no constitution in the truest sense of the word and but few written laws, although the government on the

- Mooney, Myths of the Cherokees, p. 141. 1821).

' Nuttall, Journals of Travels in the Arkansas Territory, p. 129. (Phil.

${ }^{7}$ Not to be confused with Illinois Creek in Arkansas.

${ }^{8}$ Cong. Doc. 443, No. 235.

- 1824. 
whole was very well suited to the condition of the people and the times. It seems, however, that it was administered in a rather vague manner, and the laws were more indifferently enforced than in the older community.

In the fall of 1838 John Jolly, principal chief, died. As his first assistant chief, John Brown, had previously resigned, John Looney, second assistant chief, whose term of office expired in October of the next year, was left the nominal head of the government. ${ }^{10}$ The general conditions of the country naturally led to doubt and uncertainty on the part of the people, particularly since they were not sure on what footing they really stood with the United States in regard to the adjustment of territorial rights with their eastern tribesmen, who were arriving in such multitudes as to outnumber them two to one.

While the mass of the people showed no hostility towards the newcomers, but some anxiety that adjustment might take place without injustice to them, the leaders, backed up by the Treaty men and remembering how a large party of emigrants twenty years before had proved usurpers, determined to hold on to the reins of government at all hazards. Encouraged by the Ridge faction John Brown, repenting of his resignation of a few months before, called an informal meeting of the Council to which eight members responded. These eight members appointed Brown to fill the unexpired term of Chief Jolly and made John Looney first assistant, and John Rodgers second assistant chief.

The newly appointed principal chief, responding to a request from the National Council at the Illinois camp ground, called a meeting "for the purpose of bringing about a union and consolidation of the whole nation". ${ }^{11}$ Each party now began laying its wires for controlling the convention. For sheer strength of ability and numbers the advantage was clearly to the emigrants who, in all probability, would manage the meeting so as to give themselves the upper hand in the proposed adjustment. But, as the Old Settlers and Treaty men were

${ }^{10}$ Cong. Doc. 365, No. 129, pp. 21-55.

11 Ibid, p. 4. 
not lacking in resourcefulness, the outcome held enough uncertainty to arouse the keenest interest among the people long accustomed to taking an active part in settling their questions of national importance.

The convention which met at Takattoka, ${ }^{12}$ the Old Settler capital, was attended by the chiefs and legislative councillors of both Eastern and Western Cherokees and about six thousand members of the tribe besides. After a formal reception given by the western to the eastern chiefs the councils convened separately, the Old Settlers meeting behind closed doors. Communication between the two bodies was conducted in writing, the people meantime pleasantly spending the time renewing old acquaintancs and tracing relationships as they enjoy doing down to the present time. The negotiations began by the Old Settlers requesting of the Nationalists a formal statement of their wishes in regard to the proposed union. They replied that they wished such a "joint arrangement as would thenceforth make the Cherokees a united people". ${ }^{13}$ The Western Council coldly demanded a less ambiguous statement. The answer was a proposition that the adjustments of their relations be left to a joint committee of equal members from each side and the principal and assistant chiefs of both nations.

The Treaty men, who were on the ground and much in evidence with the Old Settlers, particularly with Chief Brown, were evidently using all their influence to circumvent the $\mathrm{Na}$ tionalists. The next communication betrayed their influence too strongly to leave room for doubt. The Old Settler Council, now stepping out boldly, declared that they considered the two nations already virtually united. The Emigrants had accepted the welcome of the Western chiefs, had taken their hands in friendship, an act which they regarded as acceptance of them as rulers. The government and laws of the Cherokees from the east could not be admitted in the west; nor could two governments be tolerated in the same region; therefore the Eastern Emigrants must take the organization they found

${ }^{12}$ Or Tahlontuskee.

${ }^{28}$ Payne Mss. 5, pp. 7-15. 
already in operation when they arrived. ${ }^{14}$ The Emigrants returned a communication vehemently denying that the two people were already united and that the chiefs of the minority had any right, from prior residence in a place set apart for emigrant Cherokees generally, to claim allegiance to themselves and their laws from a body of newcomers so greatly outnumbering them. They reminded them that in removing from the east it had been proclaimed and understood by Cherokees both sides of the Mississippi that they had not relinquished a single law but had emigrated in their national character with all the attributes which had belonged to them from time immemorial as a distinct community. But for all that, notwithstanding they constituted so large a majority, they had not come to make any but just and equitable demands. ${ }^{15}$

On receiving this communication, the Old Settlers Council without further formalities adjourned and notified the waiting people that the meeting was broken up. ${ }^{16}$ The people, both Emigrants and Old Settlers, promptly resolved themselves into a national convention in which they declared that since their representatives had failed to accomplish a plan of union a National Assembly should meet July 1, at the Illinois camp ground to "recast the government upon a system applicable to their present conditions providing equally for the peace and happiness of the whole people". ${ }^{17}$ They adjourned after sending an express to notify General Arbuckle of the failure to effect a union and the determination to hold another convention in July, and to request him that no disbursements of moneys due the Eastern Cherokees nor any other business of a public character affecting their rights be made or transacted by the government agent with any other Cherokee authority until a reunion of the people be effected..$^{18}$

Meanwhile, in the midst of the discussions, the men of the Treaty party had abruptly left the council ground just be-

${ }^{14}$ Cong. Doc. 365, No. 129, p. 3.

${ }^{15}$ Ibid, p. 4 ; Payne Mss. 5.

${ }^{16}$ June 14. Cong. Doc. 443, No. 235, p. 15.

${ }^{17}$ Cong. Doc. 365, No. 129, p. 6.

${ }^{18}$ Ibid, p. 54. The Old Settlers and Treaty men were then trying to get possession of all the public moneys. 
fore the Old Settlers Council had delivered its ultimatum, but not before their presence had aggravated the old grievances up to the danger point. Feeling against them ran high and threats were heard that it was not yet too late for them to pay the penalty of the law they had broken by signing the Schermerhorn treaty. Heretofore the opposition of Mr. Ross had been so decided that all attempts to carry it into execution had been held in abeyance. Now they were decided to proceed without his knowledge. Consequently about three hundred full-bloods, every one of whom had suffered some harrowing experience from forcible removal, banded themselves together, pledged to stand by each other to the last extremity. Of the three hundred, forty were chosen to perform the work of execution. They were completely disguised and acted with such promptness and unity of purpose that in two days after the breaking up of the meeting their plan had been carried out to the letter. ${ }^{19}$

About daybreak of June 22 a band of armed men entered the house of John Ridge, dragged him into the yard and brutally murdered him before the eyes of his family. Major Ridge, attended by a servant, had started the day before to visit a friend at Van Buren, Arkansas. He was travelling down the Line $\operatorname{Road}^{20}$ in the direction of Evansville. A runner, sent with all possible speed to inform him of his son's death, returned with the information that Major Ridge himself had been shot to death from ambush on the evening of the fateful twenty-second. The third victim was Elias Boudinot whose assassination was most savage and treacherous. While helping to build a house near his home at Park Hill he was called out by three men who said they wanted medicine. He started to accompany them to the house of Dr. Worcester, the missionary, about three hundred yards distant. When they had gone nearly half way two of the men seized and held him while the third stabbed him. The three of them then fell upon the wounded and helpless man with knives and tomahawks and cut him to

${ }^{10}$ Niles' Register 56, p. 44.

${ }^{20}$ The road which followed the boundary line between Arkansas and the Cherokee Nation. 
pieces in a most barbarous fashion. ${ }^{21}$ The deed unquestionably was one of revolting brutality. Mr. Boudinot was a young man, as was John Ridge, in the prime of life; he was intelligent, well educated, an earnest Christian and devoted to the welfare of his people. His untimely taking off was the more deplorable from the fact that along with other important literary efforts he was engaged in missionary work and in assisting Dr. Worcester in interpreting and translating the Bible and printing it in Cherokee. It is not discounting the importance of the tragedy of the Ridges, therefore, to say that his loss at this time meant more to his people than the loss of any other man of the tribe could have meant, with the possible exception of Chief Ross himself. The missionary, upon reaching the side of his murdered friend exclaimed, "they have cut off my right hand", and at the open grave fearlessly declared him to be as true a patriot at heart as ever lived, the signing of the treaty being the only act of his life which anyone could condemn. ${ }^{22}$

The blow, long deferred, had fallen with a heavy, a brutal hand. While it was a shock to the whole nation and an act greatly to be deplored from all points of view it could not possibly have been a complete surprise to the friends of the victims. For, as has been suggested before, they were but paying the penalty of a law which the Ridges, both father and son, had been instrumental in placing on the statute books ten years before and which Boudinot had been the first to put into print.

The fact that the murderers were of the National party and that Boudinot was killed within two miles of Ross's home lent color to the story that he had instigated the deed. News of the affair, reaching the remotest corner of the nation in an incredibly short time, aroused the greatest excitement. The Treaty men, regarding their murdered friends as martyrs to their cause, vowed that the price of their lives should be paid

${ }^{21}$ Agent Stokes to the Secretary of War, June 24, 1839. Report of Indian Commissioner, 1839, p. 335. 1884).

${ }^{22}$ Couch, Pages from Cherokee History, p. 18. (Pamphlet, St. Louis, 
by the principal chief of the Emigrants around whom centered the storm of bitterness and hostility which raged for weeks and months in the new country, and who was made the object of threats and plots by the friends of the murdered men. ${ }^{23}$

On Sunday, June 23, a rumor got abroad that a Ridge man was collecting a party to carry out this threat. At an hour's notice a band of a hundred armed men was on the way at full speed to guard Chief Ross, while another party went to the protection of Edward Gunter, a member of the National Council included in the threat. Party feeling was at fever heat and an act of indiscretion on the part of Mr. Ross would doubtless have led to a civil war, ending in the extinction of the leaders of both parties and the destruction of tribal government. But the calmness and self-possession which had served him so well in former emergencies did not desert him in this crisis. Enjoining his friends and supporters, as they valued his favor and friendship, to refrain from any acts of aggression and violence, he sent an express to the military commander at Fort Gibson informing him of what had taken place and suggesting that, as it would probably be made a pretext by the Treaty men for further disturbances, an unbiased investigation of the matter should be undertaken. Replying to this communication General Arbuckle sent a detachment of cavalry to conduct the chief safely to the protection of the fort where the Old Settler chiefs would meet him for the purpose of arranging plans to put a stop to further acts of outrage and violence.

Meantime Treaty men and some Old Settler chiefs, among whom was John Brown, had taken refuge at Fort Gibson and sought protection from the commandant in whom they found a ready sympathy, as they did with the great majority of government officials whose obligations to President Jackson had prejudiced them against Mr. Ross. They were in favor of instant war and consulted some of the chiefs of the wild tribes, who happened to be present at the fort, to know what assistance they could furnish them in "putting down the strangers."24 459, 460.

${ }^{23}$ Report of Indian Commissioner, 1839, p. 335 ; Drake's Indians, pp.

${ }^{24}$ Cong. Doc. 365 , No. 129 , p. 55. 
Assured of the support of three or four thousand well armed allies from the neighboring nations they made their plans to rush suddenly upon the Illinois camp ground, disperse and pursue the men, not one in ten of whom was armed, and massacre every one of them, sparing only women and children. Before trying to carry the plan into execution, however, they revealed it to General Arbuckle, who advised them to postpone their vengeance and appeal to Washington for a settlement of the difficulty, and upon sober reflections they decided to act upon his suggestion.

This was the state of affairs at the fort when the escort arrived to conduct Mr. Ross to safety. His friends had also been warned of a plan to make the chief a prisoner of the United States as soon as he reached Fort Gibson, hold him to account for the murders and remove him permanently from the chieftainship. Aware of these designs upon his liberty and his life, Mr. Ross courteously declined the services of the military guard, notifying General Arbuckle that he would remain at home and depend upon his own resources for protection. ${ }^{25}$ During the last ten days of June therefore when political adjustment should have been going on smoothly and the people given every opportunity to settle down to work, planting crops and building houses, a civil upheaval was in progress such as the tribe had never experienced, and the country was torn from center to circumference by the bitterest factional strife it had ever known.

The Federal Government promptly accused John Ross of being the cause of all the trouble. Not for a moment does it seem to have recognized its own responsibility for the state of affairs in the Cherokee Nation, where its secret agents by dark and devious methods had started a train of events which threatened to blot a nation out of existence and which actually caused its people to retrograde in civilization for three decades. Even in the fourth and fifth generations there are still traces of the old factional prejudice which three-quarters of a century have been unable to entirely obliterate.

${ }^{25}$ Ibid, p. 45 


\section{CHAPTER XVI}

\section{Political Readjustment}

A judicious and non-partisan attitude on the part of the commandant at Fort Gibson and the Cherokee agent at Bayou Menard would, without doubt, have gone a long way towards quieting the tumult aroused by the tragedy of June 22. Mr. Stokes threw the whole weight of his influence on the side of peace and conciliation, assuring all factions of his earnest desire to see the nation "flourish in peace, happiness and prosperity" and of his willingness to do all he could to further this object "without partiality to anyone." It was a different story with General Arbuckle, who by profession, was a man of war and not of peace. His daily habits of life $^{2}$ tended possibly to increase his prowess as a warrior, undoubtedly to augment his ardor as a partisan, but totally unfitted him for the position of judge and arbiter in a situation requiring cool, sober and unbiased judgment.

He was a Virginian by birth, an admirer of Andrew Jackson, and a soldier of no mean ability who had been sent to the southwestern frontier fifteen years before. Fort Gibson, his headquarters, beautifully situated on some heights overlooking the Grand River valley in the Cherokee Nation, was for many years the most important center of military, commercial and social life in that region of the southwest. Here came the Choctaws, Chickasaws, Creeks and Cherokees when occasion made it necessary or desirable, and it was convenient also for the wild tribes of the plains who doubtless found a certain fascination in the military garrison with its uniformed soldiers, its drills and martial music. The Western Cherokees, particularly, found it a convenient place to buy supplies and to sell such articles of commerce as they had to offer, which were shipped by boat down the river to Little Rock or to New Orleans.

${ }^{1}$ Cong. Doc. 365, No. 129, p. 16.

${ }^{2} \mathrm{He}$ not only indulged in stronger drink than grape juice but kept a supply on tap with which to secure certain desired ends. Cong. Doc. No. 368 , No. 222, p. 20. 
Old Settler chiefs and Treaty men had established friendly relationships with the commandant of the garrison before the Emigrants arrived. Moreover, his opinions of John Ross and his followers had been highly colored by rumors from Washington during the last few years and he was thus naturally prepared to take a prejudiced view of the newcomers as soon as they arrived. Not content to confine his activities to his legitimate field of action, he proceeded to use all his good offices at Washington and his authority in the Cherokee Nation to back up the Treaty men and the Old Settlers with whom they had made common cause.

Alarmed at the turn affairs had taken in the early summer of 1839, the Treaty men sought safety under the protection of General Arbuckle and took up temporary quarters in the shadow of the fort, where, as has already been said, they were joined by the Old Settler chiefs and Council at the invitation of the military commander, who promptly sent an express to Washington to apprise the administration of what had taken place. The messenger returned in twenty-four days with orders to defend the Treaty men, support the Old Settlers, take care of such Cherokees as might manifest a hostile disposition, and demand of John Ross the murderers of the Ridges and Boudinot. ${ }^{3}$ Acting on these instructions he informed the Western chiefs that they would be recognized as the only legitimate authority in the Cherokee Nation ${ }^{4}$ and advised Chief Brown to hold on to his laws, by no means to give them up. As he would be sustained by the military, the people would eventually be compelled to submit. ${ }^{5}$

Meanwhile, the Old Settler executive committee ${ }^{6}$ had addressed a communication to John Ross declaring that the manner in which the convention had been called to meet at the Illinois camp grounds, without any notice to them, was irregular, protesting against the legal force of any acts which it might

${ }^{3}$ Payne Mss. 8, p. 9; Cong. Doc. 365, No. 129, p. 9.

${ }^{4}$ Cong. Doc. 443, No. 235, p. 16.

${ }^{5}$ Cong. Doc. 365, No. 129, p. 86. Smith.

'Composed of John Brown, John Looney, John Rodgers and John 
pass and proposing, at the suggestion of General Arbuckle, that he send a committee of his party to meet an equal number of their own at Fort Gibson on July 25, for the purpose of reaching an amicable settlement of the trouble. ${ }^{7}$ Ross replied by inviting them to attend the convention just beginning its session at the Illinois camp ground. They declined the invitation saying that they had called a council of their own people and such others as chose to attend to meet at Takattoka on July 22 where the question of union would be considered by them. ${ }^{8} \quad$ Then they proceeded to draw up a memorial demanding of the United States protection in the country and government guaranteed them by treaty, ${ }^{9}$ and asking for the moneys due the tribe.

The convention met at the appointed time and place with a large number of Emigrants in attendance and a considerable sprinkling of the Old Settlers, ${ }^{10}$ numbering some of their most enlightened and conservative men, among whom was the venerable Sequoyah or George Guess. One of the first acts of the Convention was to appoint a committee of Old Settlers to communicate with the chiefs at Fort Gibson urging their coöperation in adopting measures for preventing the further effusion of blood, effect a union "on just and reasonable conditions" and lay the foundation of a code of laws for the protection of the rights and privileges of all. "Come up without delay," wrote this committee, ${ }^{11}$ "that we may talk matters over like friends and brothers. These people are here in great multitudes and they are perfectly friendly towards us. They have said over and over again that they would be glad to see you, and we have all confidence that they will receive you with friendship. There is no drinking here to disturb the peace."12 The appeal met with no response from the Old Settlers.

The convention next turned its attention to the tumultuous condition of the country, passing such laws as were thought

${ }^{7}$ Cong. Doc. 365, No. 129, p. 59.

${ }^{8}$ Ibid, p. 67.

- Ibid, p. 66.

10 "Upwards of two thousand" in all.

11 July 2.

${ }^{12}$ Cong. Doc. 365 , No. 129, p. 66. 
best for restoring confidence and quiet. A resolution of July 7 declared that the Ridges and Boudinot had, by their conduct, laid themselves liable to the penalty of the ancient law against selling territory belonging to the tribe, and extending to the survivors a full amnesty for past offenses but upon stringent and humiliating conditions. Three days later it passed a decree securing the murderers from any prosecution or punishment and restoring them fully to the confidence of the community. ${ }^{13}$ The committee on act of union, with Sequoyah as a member, made its report on July 12 . It was adopted almost unanimously, and bears the signatures of John Ross, George Lowrey and thirteen others representing the Eastern Cherokees, and George Guess with fifteen Old Settlers for the Western Nation. ${ }^{14}$

The proportion of Old Settlers in attendance was small at first, but as the days went by the orderliness of the proceedings reassured them, and they turned out in increasing numbers. Among those who came to look on and observe the workings of the convention was John Looney, who went away well pleased and reported to General Arbuckle his good impression of the proceedings. There was a growing desire on the part of the majority of the people of all factions for a compromise and some hope was entertained that it might be brought about when the Old Settler chiefs met at the mouth of the Illinois River the last of July.

When the time arrived, however, the Treaty men, furious over the humiliating conditions of the amnesty decree, were prepared to yield not an inch. The committee, on arrival at the council ground, met with such open hostility, that fearing their lives were in danger, they retired without discharging the business for which they had been sent.

Convinced finally that no reconciliation could be effected with Brown and Rodgers, John Looney, first assistant chief, and Aaron Price, a very prominent Old Settler, withdrew from the Council, called a convention of their western people and deposed the two chiefs, Brown and Rodgers, on the ground that

${ }^{13}$ Niles' Register 56; Report of Indian Commissioner, 1839, p. 387.

${ }^{14} \mathrm{John}$ Looney's name, which appears on the document, was not attached until August 23. 
they no longer represented the will of the people, but had acted in direct opposition to their wishes in appealing to the United States for interference in their internal affairs. They then elected John Looney principal chief, giving him authority to represent the Western Nation in signing the articles of union. This he did on August 23. ${ }^{15}$

After providing for a constitutional convention to be held early in September, the meeting at the Illinois camp ground adjourned, having accomplished the purpose for which it was called. This second convention met at Tahlequah and from September 6 to 10 drew up a bill of rights and a constitution modeled closely after the one the Emigrants had brought with them from the east. Having been submitted to the people for ratification it was proclaimed the law of the land, and, according to its provisions, officers for the new government were elected. These officers were chosen from among both Emigrants and Old Settlers. John Ross was elected principal, and Joseph Vann, ${ }^{16}$ an Old Settler, second chief. In the executive council and the two legislative branches the Western Cherokees were slightly in the majority, both the speaker of the Council ${ }^{17}$ and president of the Committee ${ }^{18}$ being Old Settlers. ${ }^{19}$ When October arrived they were prepared to hold their National Council.

The Brown and Rodgers faction of the Old Settlers, refusing to recognize their summary deposition from office, called another council in October and elected John Rodgers as principal chief and John Smith, a signer of the Schermerhorn treaty, first assistant chief; Dutch, a full-blood who had distinguished himself for many deeds of daring among the western tribe, with whom his name was a word of terror, was made second assistant chief. ${ }^{20}$ Entrenched in the belief that the United States would protect them in their rights and would acknowledge theirs as the only legitimate government among

${ }^{15}$ Cong. Doc. 365, No. 129, p. 68.

${ }^{16}$ Vann had, at one time, been a chief of the Old Settlers.

${ }^{17}$ William Shorey Coody.

${ }^{18}$ Young Wolf. Cong. Doc. 366, No. 188, p. 41.

${ }^{10}$ Cong. Doc. 368 , No. 222 , p. 2.

${ }^{20}$ Cong. Doc. 359, No. 347, p. 19. John Brown had gone to Mexico to see about securing a new country for himself and his friends. 
the Cherokees they held on stubbornly to their contention for leadership, denounced the proceedings of Mr. Ross and his party, which they declared null and void, protested against the transaction of business with their delegation on behalf of the Cherokee Nation, and demanded that the tribal funds be refused them. ${ }^{21}$

General Arbuckle, while disavowing all intention of meddling with the internal affairs of the Cherokees, but imperfectly concealed his eagerness to do so. ${ }^{22}$ The readiness with which he gave ear to the wildest rumors started by partisans and his manner of making reports to the Department of War so as not only to indicate the measures to be supported but also the men to be upheld, betrayed him. Secretary Poinsett, who proved himself hardly less partisan, gave full credit to these reports, qualified as they were with "perhaps," and "I believe that I am justified in making the assertion," or "as I judge," ${ }^{23}$ and distinctly informed the newly organized government that only such information was acceptable as was being received from the military, and not from the agency where Governor Stokes showed a much more judicial attitude.

An occurrence at the Fort soon after the act of union is illustrative of his attitude at this time. Charles Coody and Looney Price, two Old Settlers who had signed the Act of Union, called upon him and found him much excited about the conciliatory course of so many of the Western Cherokees. $\mathrm{He}$ expressed great surprise that Charles Coody had taken such an active part. Coody answered that if every man would make the proper effort at this crisis a reconciliation would soon be effected and the whole nation would soon be happy and at peace. Whereupon the General bitterly exclaimed, "You too-you shouldered a rifle and went with all the rest to guard John Ross; but for that, John Ross would have been killed!"24

${ }^{21}$ The Government was holding up payments of all moneys due the Cherokees until a settlement of their difficulties could be reached. Cong. Doc. 359 , No. 347, p. 16.

${ }^{22}$ Report of Indian Commissioner, 1840, p. 46 ; Royce, Cherokee Nation of Indians, pp. 294, 295.

${ }^{28}$ Cong. Doc. 359, No. 347.

${ }^{24}$ Cong. Doc. 368, No. 222, p. 3. 
General Arbuckle grossly misrepresented the articles of union in order to convince the War Department that sharp practices had been used in ratifying them and that they contained sentiments which made impossible any peaceable settlement of the factional trouble.

In his eagerness to put Mr. Ross in the worst possible light before the administration he frequently showed, in his reports, not only vindictiveness but positive lack of candor, while his effort to prejudice the Western Cherokees against Ross is ill concealed. Moreover, the obligation of the Federal Government to the Treaty men who had been its tools in making the Schermerhorn treaty, was such as to make it difficult for its officers to take a judicial and tactful attitude towards the whole situation. To General Arbuckle it was not only difficult but impossible. In a high-handed and dictatorial manner he demanded that the murderers of the Ridges and Boudinot be turned over to him and assurance given by Mr. Ross that he would be responsible for the conduct of his followers in the future, threatening to send the militia through the country unless this demand were complied with. Mr. Ross protested politely, yet vigorously, against such a course, saying that he refused to be held responsible in any way for the murders which he so much deplored. As the murderers were unknown to him he could not apprehend them, nor would he send them to Fort Gibson if he could. It was in his opinion a local affair and one which the Cherokees themselves were competent to control and adjust in the manner most conducive to the peace and welfare of the nation without interference from the United States. ${ }^{25}$

This angered General Arbuckle so much that he accused Ross himself of being the murderer or the instigator of the deed, since he was admittedly the protector of the assassins, and he was on the point of arresting and placing the chief in confinement when he found that Mr. Ross was ready to start to Washington with his delegation. ${ }^{26}$ As his arrest and detention

${ }^{25}$ Evans Jones to John Howard Payne. Payne Mss. 5; Cong. Doc. 365 No. 129, p. 109; Cong. Doc. 366, No. 188, p. 16.

26 Ibid, p. 25. 
in the east would be likely to prove more embarrassing to the chief and less so to the commandant, Mr. Ross was allowed to depart unmolested, but not before General Arbuckle had dispatched an express to the Capital artfully suggesting the course which should be pursued toward him.

Thus when the delegation from the newly organized government presented itself and requested an interview with Secretary Poinsett he bluntly refused to receive them with John Ross, whom he violently denounced as the instigator of the murders of the Ridges. The delegation refused an interview without the chief and demanded evidence for the accusation against him; to which Mr. Poinsett replied that evidence would be produced in the progress of the investigation which had been instituted. ${ }^{27}$ The evidence was never produced, however, and the Secretary, when cornered, had to admit that no investigation had been instituted as he considered none necessary as long as Ross did not give up the murderers.

The winter and early spring were spent in fruitless efforts to secure an adjustment at Washington, and equally fruitless efforts in the Cherokee Nation to bring the two factions together.

During all this time the tribal funds were being held up, and the people, unable to secure supplies, were suffering for want of the necessaries of life as well as from political dissensions. ${ }^{28} \quad$ A settlement of the controversy in some manner became imperative, but how it was to be accomplished was not at all clear. When in November the Secretary of War announced to the Commissioner of Indian Affairs that the rule of the majority was a principle as applicable to the affairs of the Cherokees as any other community, and that the minority must eventually yield to the great mass, it seemed that light might be dawning on the situation. ${ }^{29}$

Acting on this ruling and by the advice and assistance of Agent Stokes, a meeting was held at Tahlequah, January 15, for the purpose of deciding by vote which government they

${ }^{27}$ Cong. Doc. 359, No. 347, p. 21.

${ }^{23}$ Cong. Doc. 365 , No. 129, p. 38.

20 Ibid, p. 5 . 
would choose for their nation, "in order that peace and friendship may be restored throughout the country and the Government of the United States satisfied as to the will and choice of the Cherokees in relation to this matter." 30 A special invitation was sent the Old Settler chiefs to join them; but when the assembly met at the appointed time they failed to appear. The first act of the assembly was to repeal the decree of outlawry against the Treaty men which had given so much offense at Washington and cause for complaint in the Cherokee Nation. The people present expressed themselves unanimously ${ }^{31}$ in favor of the new government and signed the articles of union, a certified copy of which bears one hundred and fifteen names of Western Cherokees. ${ }^{32}$ Captain Page, who attended the meeting as General Arbuckle's representative, reported that upon counting the total number of votes cast he found them to be between seventeen and eighteen hundred..$^{33}$

There was clearly a majority in favor of union and the constitution. Agent Stokes recognized it, and General Armstrong $^{34}$ wrote the Secretary of War that, in view of the late ruling of the War Department, since the convention had decided in favor of the union and the decree of outlawry had been repealed placing all upon an equal footing, he had determined to recognize the late government in such transactions as he and his agents might have with them, adding that he considered the peace of the country the great object to be obtained: it was a matter of no importance to the Government who ruled, provided the obligations of the United States be recognized. He recommended that, since now there was a fair prospect of harmony being restored, the money due them be paid. ${ }^{35}$

${ }^{80}$ Cong. Doc. 365 , No. 129, p. 17. The Treaty party and Old Settlers refused to attend because they regarded the invitation to meet as having no other object than revealing the weakness of their numbers. Ibid, p. 34 .

Gen. Arbuckle refused to attend because the Old Settlers and Treaty men would not go. Ibid, p. 42.

${ }^{31}$ With the exception of one man.

${ }^{32}$ The Cherokees were in advance of their times on the question of equal suffrage.

${ }^{33}$ Cong. Doc. 359, No. 347, p. 45.

${ }^{84}$ Acting Superintendent of the western territory.

${ }^{35}$ Cong. Doc. 359, No. 347, pp. 51-2. 
The victory of the unionists was not so acceptable to General Arbuckle, who acknowledged ${ }^{36}$ with reluctance that it now became his duty in accordance with the ruling of the Executive and the decision of the convention to notify the Old Settlers that their government was at an end. He had no doubt, he wrote, that the decision would be keenly felt by the Old Settlers, who in their kindness had invited the late Emigrants to share their country with them; in less than a year after their arrival the newcomers had wrested the authority out of the hands of their benefactors. Unless something were done to satisfy the Old Settlers he feared outrages and bloodshed might be expected. They would not peaceably surrender their rights and had expressed the intention of claiming from the United States undisputed possession of the seven millions of acres of land to which they were entitled. He suggested that if he were permitted to exercise his own judgment he would at once dissolve the two governments and form a third. ${ }^{37}$ The letter was followed up by a memorial from the western chiefs protesting against the decision of the late convention, and together they had the desired result.

In spite of a letter from Agent Stokes stating that there was nothing in the new constitution to encourage murder and, as a result of conversations with five or six Old Settlers, he judged that the murders were not sanctioned by the chiefs and principal men, ${ }^{38}$ the Secretary of War ordered General Arbuckle to bring about a new constitution securing the rights of the Indians, the abolition of such savage and cruel edicts as that under which the Ridges and Boudinot were slain, conformity to the United States constitution and the exclusion from office of John Ross and William Shorey Coody. ${ }^{39}$

Ross and Coody immediately protested vigorously on the ground that the United States had no control over their internal affairs, but the War Department was obdurate. General Arbuckle had at last succeeded in getting the desired authority

${ }^{26}$ Jan. 22, 1840. Ibid, p. 50.

${ }^{87}$ Cong. Doc. 359, No. 347 , p. 51.

${ }^{38}$ Ibid, p. 51.

${ }^{39}$ Cong. Doc. 366 , No. 188 , pp. 54-6. 
into his hands and his love of power was keenly gratified. Acting on instructions, he declared both governments dissolved and called a conference to be held at his headquarters, July 25, to which each party was requested to send deputations of twenty-five or thirty men. Both parties opposed this plan of settling the difficulty, but the General was in the saddle and prepared to ride roughshod over all opposition.

Then the unexpected happened, taking him completely off his guard and forcing him to either go down in ignominious defeat, or to make terms with the enemy. A few days before the time for the conference arrived, a call council of the Nationalist government met and quietly appointed its full quota of delegates. The delegation composed of some of the ablest men from the Emigrants and Old Settlers went over to Fort Gibson thoroughly organized, with a well defined purpose in mind and a copy of their Acts of Union and Constitution in hand. They were also prepared to prove that they represented a majority of the Cherokee people, both Emigrants and Old Settlers.

The Old Settler Council had made no such preparation to defend its interests. 'The principal and assistant chiefs with a number of their leading men casually appeared on the ground but no authorized deputation had been named to represent them. At the last moment Chief Rodgers was compelled by the exigencies of the situation to appoint some of his friends to act for his party. From the start, therefore, the advantage was clearly with the Nationalists who had not only a well defined policy to guide them but the support of the people to back them. General Arbuckle, appreciating the significance of the situation felt compelled to advise the Old Settlers to give in. They at first refused to do so, but after considerable delay, during which the Nationalists made it plain that they could act upon no other basis than the complete acceptance of their Acts of Union and Constitution, the Old Settlers, on assurance from their friend, the General, that they could accept them without acknowledging their legal force until they had been concurred in by their people as a nation, came to terms and signed an agreement. Acceptance of the Acts of Union and the Constitution of the Nationalists was a practical recognition of the government organized under them. 
The statement of the conditions is very ambiguous and they were doubtless differently understood at the time, but the whole tribe, worn out with the year of contention and disorganization, was glad to agree to any compromise that promised a degree of peace and harmony. Even Chief Rodgers of the Old Settlers, while personally opposed to the union, gave a toast, "What has been done this day, may it never be undone." The agreement was signed by eleven members of the Eastern Nation and twelve from the Western. Although there was never any subsequent action on the part of the Western Cherokees concerning the compact the Federal Government considered it binding, and for all practical purposes recognized the government from which neither John Ross nor William Shorey Coody had been excluded.

Mr. Ross had thus emerged triumphant from the tumult and heat of the conflict, as cool and level headed, apparently, as if it were a game of Indian ball he had been playing. Never for a moment had he wavered in his determination to prevent the overthrow of his own party and make it the dominant political force in the new country. The motive which prompted him was doubtless, to some extent, self-aggrandizement, but that it was dominated by true patriotism his followers never doubted for an instant. Whatever sharp political practices the chief was tempted to make use of, either now or in later years, he had learned in the hard school of experience, and from tutors provided by no less an institution than the United States Government.

${ }^{40}$ Cong. Doc. 457 , No. 140 , p. 67. 


\section{CHAPTER XVII}

\section{Political Readjustment, Concluded}

The National Council selected for the location of its capital the site of an old Ute Indian village, abandoned more than half a century before, situated in a narrow valley overlooked by oak-clad ridges. The place commended itself to them partly on account of its sheltered position and salubrious climate, and partly, no doubt, from the fact that the lay of the land and the character of the country round about bear some slight resemblance to their ancient nation. On the north a rocky prominence smooths out into an open prairie which after a few miles merges in a heavy forest. To the southward the broken ridges, interspersed with forests and fertile valleys, at length give place to rugged hills beyond which rise more rugged hills until they lose themselves in the dimness of the purple distance. A little creek, bearing the accumulated waters of many hillside streams, flows over a stony bed down through the town and, together with a number of nearby springs, furnishes an abundant supply of water for man and beast. In many ways it was an ideal spot for the purpose for which it was chosen. They named it, not New Echota, but Tahlequah, for the ancient village of Talikwa or Tellico which held less tragic associations for the tribe than their former capital.

Here they laid out the council ground in the form of a square, of the dimensions of a city block and enclosed it with a rude fence, within which a temporary shed sheltered the first meeting of the Council. A log cabin served as executive office. During the next year the shed was replaced by log houses built on two corners of the capitol square, one for the accommodation of the legislature, the other for the judiciary. Several years later the log houses, in turn, gave place to a twostory brick council house built in the center of the square.

The first Council met between September nineteenth and October twelfth and in quick succession passed laws for punishing criminal and other offenses, regulating settlement on the public domain, the adjustment of certain cases by arbitration, 
prohibiting the vending of ardent spirits, granting permission to locate new mission stations, establishing a school system and a judiciary. In addition to these there was various other legislation necessary for putting the machinery of government into motion. ${ }^{1}$ Just as in the old nation, the country was divided into eight districts, ${ }^{2}$ for the purpose of apportioning representation in the Council and the Committee, and for greater ease in administering the school system and the local affairs of the different sections.

By the compromise arranged at Fort Gibson in the summer of 1840 it was hoped and confidently believed that peace and harmony had been permanently restored. According to the agreement one-third of the officers elected under the new constitution promptly resigned, and Chief Rodgers, representing the Old Settler government, appointed Western Cherokees to fill the unexpired term with the distinct understanding that thereafter each one, regardless of party affiliation, was to take his own chance at election. When Council convened in October, 1840, therefore, the new officers appeared and took their places after having pledged themselves to support the constitution.

The delegation from the National party sent to Washington the previous winter returned home in October, after having been absent for almost a year. The news they brought as revealed in the principal chief's message ${ }^{3}$ was far from encouraging to a community embarrassed to the point of individual starvation and national bankruptcy. The unsettled condition of the country and the conflicting claims of rival parties had given the administration some excuse for evasion and delay, not only in turning over the annuities, but in carrying out the terms of the treaty. The real reason for the latter, however, is not to be sought in the wilds of the southwest but in the treaty itself whose Delphic vagueness began to grow embarrassing enough to the Senate and the Executive when time came to "settle up" the financial end of the bargain. Those who had agreed

${ }^{1}$ Cong. Doc. 411, No. 1098.

${ }^{2} \mathrm{~A}$ ninth was added later and given the name Coowee Scoowee, John Ross's Indian name.

${ }^{2}$ Cong. Doc. 411, No. 1098, p. 45. 
with Mr. Lumpkin that it was the best treaty ever entered into with an Indian tribe were now forced to take refuge in meaningless generalities when their opinion was sought as to the real meaning of the treaty. Even the Senate which had approved the document could shed no light upon it, nor was the President or the Secretary of War able to reconcile its contradicting statements as to whether the expense of removal should be subtracted from the five million to be paid for the old nation or whether it should be borne by the United States. By article eight the Federal Government made itself plainly liable for the expense of removal and by article fifteen this same item, together with the charge for subsistence, is enumerated with other expenses to be taken out of the amount paid the Cherokees for their eastern lands. Supplemented articles to the treaty, which had been found necessary to give character to the original document before it could even pass the Senate, cleared up some points, but on others rendered the confusion worse confounding.

To add to the complication the Old Settlers now claimed that if they were to be forced to share their country with the newcomers they should share with them in the per capita payment which was to be made of all the moneys remaining from the sale of the eastern lands after expenses were paid. Also, the Treaty men claimed that, since they had been allowed only twenty dollars per capita for removal while the Emigrants had been promised three times as much, they should be reimbursed for the difference. These conflicting claims added to the complication and the Van Buren administration, now nearing its end, took no definite step towards reducing it to order and harmony. The delegations at Washington in the winter of 1840-1841 appealed in vain for a final interpretation of the treaty and a complete execution of all its terms. The Indians and their troubles were too remote, cut no figure in the present political situation and the future was not yet to be reckoned with. With the Cherokees safe beyond the Mississippi, the President and Congress had been glad to free their minds of them. It seemed impossible to attract any intelligent attention at this time and affairs drifted on into the next administration, while the Cherokee government was bankrupt and many of the people were in want of the necessaries of life. 
With the accession of the Whigs, who had loudly denounced Jackson's force policy, high hopes were entertained of a change of policy towards the Cherokees. But weeks passed into months before they succeeded in gaining the ear of the executive. Finally in September President Tyler addressed to the delegation a letter in which he deplored the injustice they had suffered at the hands of the Federal Government and promised that, as far as lay in his power to prevent it, no Cherokee should ever again petition in vain for justice. He had carefully read the various treaties, he said, wherein he found promises of friendship on one side and of protection and guardian care on the other. He had read Washington's address to the delegation of the nation as it was inscribed in the silver bound book, presented to them at Philadelphia, wherein he found a record of the mutual obligations existing between his government and that of the Cherokee Nation. He also read the talk made by Jefferson inscribed upon a parchment and surrounded by an endless chain of gold. "Let us keep that chain bright and unbroken," he enjoined them; "In its preservation consists our mutual happiness." A new treaty was then promised, giving them indemnity for all their wrongs, establishing upon a permanent basis the political relations between them and the United States, and guaranteeing their lands in fee simple. In closing, President Tyler prophesied that a new sun would soon dawn upon the Cherokee people in whose brightness their permanent happiness and true glory might be read by the whole world. "And I shall rejoice to have been the President under whose auspices these great and happy results shall have been produced.".4

Mr. Ross and his delegation joyfully carried this letter home to read to their Council in October, 1841, where they found some excitement existing over a rumor that a "head right" payment of the money would be made under the New Echota Treaty. Many were in favor of accepting what the government was willing to pay them without further delay that their distressed condition might be relieved. ${ }^{5}$ Chief Ross coun-

${ }^{4}$ Cong. Doc. 411, No. 1098, pp. 71, 72.

Ibid. 
seled delay in the belief that under a new treaty they would receive millions, whereas under the New Echota Treaty they would receive only a few thousand, which, paid per capita, would amount to a comparatively small sum. ${ }^{6}$ After a fierce debate the chief's policy prevailed and a new treaty was confidently looked forward to as a panacea for all their political ills.

With a view to carrying out this promise, the President instructed the Cherokee agent through the Commissioner of Indian Affairs to procure all the information possible upon the subject of the injustice done the members of the tribe to the end that amends might be made them as far as possible. The Secretary of War, acting upon this report, went so far as to prepare the draft of a new treaty, but it was so far from satisfactory to all parties that the effort at adjustment came to naught.

Meantime the possibilities suggested by Mr. Tyler's letter had been working sad havoc among the newly reconciled parties at home. Should investigation prove that large sums of money to be paid per capita, were rightfully due the tribe, would members of all parties share and share alike or would the Emigrants claim, and by their superior numbers and political strength secure the lion's share? These were questions which began to agitate the minds of the opposing factions. Lawyers, thinking they saw rich fees in contesting claims, were not slow to lend a hand at setting in motion a train of influences which soon produced a repetition of all the old party wrangling and bitterness. Old Settlers and Treaty men put forward separate claims conflicting with those of the Cherokee national government. The Western Cherokees, with whom the Ridge men usually made common cause, attempted to establish their government at the mouth of the Illinois River. The Cherokee national authorities tried to suppress the movement on the ground of treason, and the opposition, angry and resentful, appealed to Washington to have a certain section of the nation set apart for them, complaining that they could not live in peace and harmony with the Ross government. The administration at loss to know what to do took refuge, as usual, in inaction.

${ }^{6}$ Ibid. 
Meanwhile Chief Ross and the Cherokee Council were not idle. After having failed in the attempt to restore harmony and unity at home they dispatched a delegation to Washington in the winter of 1843-44 to head off the secession movement by arranging a new treaty. Armed once more with President Tyler's letter they appeared at the National Capitol and presented to the Secretary of War a statement of the salient points on which they desired to negotiate a new agreement. Representatives of the other two factions were also present ${ }^{7}$ and their hostility to the Ross party caused the President to decide that the cause of turbulence in the tribe must be obtained and responsibility for it fixed before a new treaty could be considered. Charges had been brought against the dominant party claiming that grievous oppressions were practiced by them, insomuch that their opponents were not allowed to enjoy life, liberty and the pursuit of happiness, and that the act of union was never authorized or sanctioned by the legal representatives of the people. The Nationalists contended that the Western Cherokees and the Treaty party enjoyed the same degree of security and the same fullness of rights enjoyed by any other part of the nation, and counter charged that the alleged dissatisfaction was confined to a few restless spirits whose motto was "rule or ruin".

Unable to reconcile these contradictions, President Tyler appointed a commission to inquire into the disturbances and the grievances of the weaker parties. This commission, composed of General R. Jones, Lieutenant Colonel R. B. Mason and Mr. P. M. Butler, ${ }^{9}$ the Cherokee agent, arriving at Fort Gibson in the early winter, issued a proclamation stating their business with the Cherokees and inviting them to come in and register any complaints which they might have against the party in power. Conferences held at different places were well attended, over nine hundred being present at one meeting, and a thorough investigation was made lasting over several weeks.

${ }^{7}$ Cong. Doc. 476, No. 331, p. 18; Royce, Cherokee Nation of Indians, pp. 300,301 .

${ }^{8}$ Ibid, p. 301.

- Cong. Doc. 476, No. 331, p. 20. 
Based on this investigation, the commission made its report which stated that, after an impartial examination of the facts in the case, the committee was thoroughly convinced that the authority for the proceedings on either side at Fort Gibson in July, 1840, was adequate, since the representatives of the Western Cherokees who had attended and taken part in the deliberations were regarded by both Eastern and Western Cherokees as authorized agents; that the stipulations in regard to office were at once carried out, and many of those now denying the validity of the compact had taken office under it, and consequently had taken the required oath; and while the proceedings were never referred back to the people there was probably no intention that they ever should have been-at any rate, the reason that they were not, seemed to have been not the fault of the Ross party. Chief Rodgers and others had received money from the new government for claims under the old. The complaining party had acquiesced in the new government and, in the succeeding election, party lines seem to have been obliterated and the Western Cherokees had received the majority of the offices. As to the moot question of per capita payments, the committee held the opinion that all parties stood on an equal footing. It further reported that the complaint of oppression against the Ross party since the act of union, was unfounded and that no life had been endangered by them except in the administration of wholesome laws; but there was great danger to life from frequent and stealthy incursions of a desperate gang of bandit half-breeds, notorious in the nation as wanton murderers, house burners and horse thieves, but whose fraternity was not of the dominant party; among the mass of the people there was no discontent, the bitterness and hostility to the dominant party being confined to only a few. The commission concluded its report by recommending a new treaty on the basis of President Tyler's letter. ${ }^{10}$

The investigation had been comprehensive, thorough; its report was clear, logical, and based on the real merits of the case. It would seem that there was no occasion for further delay, but that the time for action had arrived. Justice to all

${ }^{10}$ Cong. Doc. 4.57, No. 140, pp. 5-14. 
parties demanded it. When the report of the commission reached the President, however, the country had just emerged from the throes of another presidential election resulting this time in the final overthrow of the Whigs. Mr. Tyler, with an eye single to the annexation of Texas, was willing to leave the much vexed Cherokee question to the tender mercies of his successor, who during the first months of his administration, was too concerned with important foreign relations and domestic affairs to trouble himself much about distracted Indians.

Seeing no probability of adjustment, and having become satisfied that it would be impossible for them to maintain a peaceful and happy residence in the Cherokee Nation while John Ross and his party remained dominant, the Old Settlers and Treaty party, in the fall of 1845, resolved to seek a new home in Mexico. An exploring party of forty was sent out to find a suitable location. On their return a meeting was held at which it was decided to ask the United States to provide them a home in the Texas country upon the relinquishment of all their interests in the Cherokee Nation; or to assign a section of the Cherokee Nation to them with the privilege of adopting their own form of government and living under it without molestation. General Arbuckle and the Governor of Arkansas approved the measure and urged upon the authorities at Washington the necessity of legislation to carry it into effect. ${ }^{11}$ In response to their request the Commissioner of Indian Affairs, William Medill, utterly disregarding the report of the Tyler commission, sent to President Polk a communication approving the plea and claiming that the act of union between the factions was of no binding force. ${ }^{12}$ Influenced by this report the executive, in a message to Congress April 13, 1846, recommended that, as there was no probability of the different parties being able to ever live together in peace and harmony, the well-being of the whole tribe required that

${ }^{11}$ Letter of Agent McKissick to the Commissioner of Indian Affairs, May 12, 1846; and General Arbuckle to Secretary of War, Feb. 12, 1848; also report of Agent McKissick July 4, 1846; Report of Commissioner of Indian Affairs, 1846.

${ }^{12}$ Cong. Doc. 470, No. 298. 
they should be separated and live under different governments as distinct tribes. ${ }^{13}$

The National party resented this recommendation and vigorously objected to any Federal interference with their internal affairs, particularly to having their country divided and the authority of the United States courts extended over them, ${ }^{14}$ regarding it as a distinct violation of the article in the New Echota Treaty ${ }^{15}$ promising the Indians protection in the laws which they should make, providing only that these laws should not be inconsistent with those of the United States. While the project of separation was not carried out, it served to encourage the belief of the weaker parties that the Federal Government would interfere in their behalf, and to the detriment of the whole tribe, to keep the factional spirit keyed to the highest pitch. Personal and party feuds resulted in a series of murders which led to the organization of bands of all factions for the purpose of depredation, retaliation, or protection; and the country was again plunged into a reign of terror.

The situation in the summer of 1846 became so serious that all parties recognized the necessity of the immediate settlement of the trouble. Accordingly, at the suggestion of the three factions whose representatives were in Washington, a commission was appointed with power to examine into the cause of the controversey and adjust them if possible. ${ }^{16}$ As a measure of precaution a memorandum of agreement was drawn up, which bound all parties to abide absolutely by the decision of the commission and to sign such agreement as should be necessary to insure the execution of a treaty. The result was the conclusion of a treaty on August 6, 1846. ${ }^{17}$

It stated that "The lands now occupied by the Cherokee Nation should be secured to the whole Cherokee people for their common use and benefit", the United States to issue a patent

\footnotetext{
${ }^{13}$ Richardson's Messages and Papers of the Presidents, IV, p. 430.

${ }^{14}$ Cong. Doc. 476, No. 33.

${ }^{15}$ Article 5.

${ }^{16}$ Commissioner of Indian Affairs to Major Armstrong, June 24, 1846.

${ }^{17}$ Ratified and proclaimed by the President, August 17, 1846.
} 
for the said land which, in case the Cherokees became extinct or abandoned the country, should revert to the United States; it was agreed that difficulties and party differences should cease; a general amnesty for all offenses was declared, and laws were to be passed for the equal protection of all; all armed police or military organizations were to be disbanded and the laws executed by civil powers; the United States agreed to reimburse to the Cherokees all sums unjustly deducted from the five million dollars under the treaty of 1835 , and to distribute what remained of that amount according to the treaty. As to the claims of the Old Settlers to sole ownership of the lands of the Western Nation it was decided that they had no exclusive title as against the Eastern Cherokees who, by the treaty of 1835, had acquired a common interest in the western lands. On the other hand the Old Settlers were to be given one-third interest in what remained of the five millions received for the Eastern Nation, which was to be paid per capita. The Treaty Party was to be indemnified to the amount of $\$ 115,000 .{ }^{18}$ The sum of $\$ 2,000$ was allowed for the printing presses seized by the Georgia Guard in 1835 , and $\$ 5,000$ was to be equally divided among those who had been deprived of their arms by General Scott. ${ }^{19}$ The treaty left to the Senate to decide whether the amount of subsistence was to be chargeable to the treaty fund and whether interest should be allowed, and at what rate and from what time. A clause also provided that the treaty should not take away from the Cherokees still living in the east their right to citizenship in the Cherokee Nation. ${ }^{20}$

After all the years of bickering and delay, confusion and bloodshed, there was at last a treaty for justice and peace. What could have been more welcome to the distracted tribe than the adjustment of their standing with the United States and the establishment of peace and harmony at home? The bitterness of party feeling, however, was too deep-seated to yield, at this stage of the game, to so simple a remedy as a mere paper contract. Nor did the treaty-bring the long expected and much needed financial relief to the country.

${ }^{18} \$ 5,000$ going to the heirs of Major Ridge, and an equal sum to the families each of John Ridge and Elias Boudinot.

${ }^{19} 9$ United States Statutes at Large, p. 871.

${ }^{20}$ Ibid. 
The elucidation of the ambiguous document was not the work of days or weeks but of months and years. After two years' study and deliberation Commissioner Medill expressed it as his opinion that the five million dollars was in full for the entire session of the eastern land and nothing more should be paid for removal, subsistence or any other purpose. ${ }^{21}$ Against this interpretation the Cherokees entered a vigorous protest, and disagreement ${ }^{22}$ and contention on the part of both sides delayed a settlement; the question in all its perplexity drifted on for another couple of years. It was not until August, 1850, that the Senate Committee to whom the treaty had been referred reached a conclusion. Their decision upheld the claim of the Cherokees that the charge for subsisting the emigrants during and a year after removal ought to be borne by the United States, and that the expense of removal agents was not rightfully chargeable to the Cherokees, but should be borne by the Federal Government. 'Their award for these things, however, was very conservative, and far from what the Cherokees had a right to expect.

After the amount of the award had been fixed there was further delay in securing the necessary appropriation by Congress. The last item was provided for by an act. of February $27,1851 .^{23}$ This was done with the requirement that it should be in full settlement for all claims and demands of the Cherokee Nation against the United States under any treaty theretofore made by them. Instructions were finally issued in September to John Drennan, Superintendent of the Southern Division, to proceed without delay to make the payment. Thus Georgia had been in full possession of the Eastern lands of the tribe for fifteen years before the original owners had received any compensation whatever for them.

Neither the Old Settlers nor the Emigrants were satisfied with the decision of the Senate. The former received what was paid to them under protest lest their acceptance of it should be so construed as to prevent them, in the future, from

${ }^{21}$ Cong. Doc. 521, No. 65, p. 6.

${ }^{22}$ Cong. Doc. 511, No. 146.

${ }^{23}$ Cong. Globe, 2nd Session 31st Congress, p. 602. 
urging claims which they considered just but which were not admitted by the treaty. Before accepting the money and complying with conditions prescribed by Congress, the National Council registered its disapproval by a set of resolutions solemnly protesting against the injustice its people had suffered through the treaties of 1835 and 1846, copies of which they sent to both Houses of Congress.

The per capita payment brought a short period of individual prosperity which showed itself in improved farms and farming implements, better buildings, and larger herds of cattle and horses. The Cherokee government, unfortunately, did not share this prosperity. With no revenue other than the small income derived from the invested funds in the United States, and with the heavy expenses incurred by the establishment and maintenance of schools and the carrying on of the government, the national debt increased year by year until it assumed embarrassing proportions. The district schools began to languish for lack of funds and the high schools, in which they had taken such pride, were finally closed for the same reason.

To add to the perplexity there swept over the southwest in the summer of 1854 a blasting south wind accompanied by a drought which blighted the promising crops, parched the vegetation and caused a partial water famine.' Taken utterly by surprise, the people were unprepared for such an emergency and before the end of the year many of them had been reduced to destitution amounting almost to starvation. In this situation, in the fall of 1854, they determined to send a delegation to Washington for the purpose of arranging, if possible, the sale of some of their surplus detached lands as a measure of relief from the burden of their public debt, and to replenish their exhausted school fund. A large part of the winter was spent in fruitless negotiations and the delegation was at last forced to return home empty handed, much to the disappointment and dissatisfaction of their people. ${ }^{24}$

The only point gained was the removal of the garrison at Fort Gibson. This was not actually accomplished, however, until three years later. In 1857 Chief Ross in his message to

${ }^{24}$ Report of Commissioner of Indian Affairs, 1854. 
the Council authorized the site of the abandoned post to be laid off into town lots and sold to Cherokee citizens, the proceeds to go into their national treasury. Provision was made for the preservation of the burying grounds which contain the remains of several United States officers. The sale of the lots netted the nation the sum of $\$ 20,000$, not a large amount, to be sure, but it was of some help. Notwithstanding civil unrest and financial embarrassment, together with other handicaps and annoyances, the Cherokees continued to gain ground slowly but surely, showing administrative ability of no mean order and a real capacity for Anglo Saxon civilization, the theory of certain sociologists to the contrary notwithstanding. 


\section{CHAPTER XVIII}

\section{Two Decades of Economic Development}

Having followed the political fortunes of the Cherokees in the west it may be of interest to glance at their industrial and educational development during the two decades following removal.

Confused by the unsettled state of their own, and embarrassed by the dilatory policy of the Federal Government, the Emigrants, nevertheless, had lost little time in trying to adjust themselves to an unfamiliar environment and to gain an economic footing in the new country. But a period of "hard times" was not to be avoided. The subsistence promised for one year by the United States ${ }^{1}$ could not be depended upon. Rations, dealt out irregularly, were frequently of such inferior quality as to be practically unfit for use. The flour and meal were musty and the beef, grass fed, was tough and unwholesome. For a supply of fresh meat they had to depend almost entirely upon primitive traps, blow guns, bows and arrows, and gigs ${ }^{2}$ the guns of which they had been deprived in the east just before removal had neither been returned nor paid for. ${ }^{3}$ The problem of building houses and clearing and cultivating fields was made difficult by the scarcity of carpenters, tools, and farming implements which the cost of transportation to such a remote region made doubly dear, and which most of the people had no money to buy at any price.

They would have fared ill, indeed, the first few months after their arrival but for the older members of the community. In spite of political feuds and personal quarrels the main body of the Old Settlers received the newcomers with that hospitality to which they had been accustomed from time immemorial, which was a part of their ancient religion, and which they had not yet outgrown. And so nearly connected by bonds of kinship and clanship were the two divisions of the tribe that the helping hand of the one had not far to reach in order to relieve

${ }^{1}$ Treaty of 1835.

${ }^{2}$ For spearing fish.

3. The treaty of 1846 contains an item of $\$ 5,000$ to cover their value. 
the need of the other. The loan of a plow or an axe for several days, or a few bushels of corn until a crop was made, the gift of a hen and a setting of eggs, the use of a loom and enough yarn to weave a blanket or some cloth, helped to tide over the crisis and give "a start" to these victims of Andrew Jackson's Indian policy backed up by Anglo Saxon acquisitiveness under the guise of necessary economic development. The proverbial "lazy Indian" was hard to find among the Cherokee people for many years. It was a case of work or do worse with most of them; and, although they have always been considered an abstemious people with few and simple wants, for a time, it taxed their ingenuity and energy to the utmost to provide the merest shelter and the barest subsistence. But the knowledge of agriculture and household arts learned in the old nation was gradually adjusted to meet the needs of the new in spite of various drawbacks; and, in the course of a few years, there were good farms and comfortable homes with vegetable gardens, and orchards, for the more thrifty, while the most unprogressive full-blood had his log cabin and his maize patch.

The land was found to be more desirable than had been expected. The uplands proved to be good farming land, while the river valleys were very fertile, and when cleared and cultivated produced richer harvests than the Georgia and Tennessee fields had afforded. Grass grew luxuriantly on the prairies, furnishing abundant pasturage for cattle, horses and sheep which throve marvelously without care or expense. Hogs ran wild in the woods, fattened on the mast and multiplied by tens. Game, such as prairie chickens, wild turkeys and deer, was plentiful, and wild fruit and berries flourished in their season.

As in the old nation, the land was held in common, the improvements only being the exclusive and indefeasible property of the individual. ${ }^{4}$ Any Cherokee citizen, natural or adopted, might fence a farm and improve a home wherever his fancy or business judgment suggested, so long as he did not encroach upon the rights of a former settler. The unfenced land was the common property of the tribe.

4 Art. I, Sec. 1 of the Constitution of 1839. 
There was no provision made for white settlers, except in the law making it compulsory for a Cherokee citizen employing a white man, to secure a permit, for which he paid by the month or the year, whether the laborer worked for wages or rented the land for a certain per cent of the crops. Another law granted to certain United States citizens the privilege of establishing stores of general merchandise and engaging in trade under a license from the Cherokee government.

Intermarried whites were given practically the same rights and privileges as the Indians themselves except that of holding office, but outsiders were not encouraged to come into the nation; those who persisted in doing so were considered intruders and shown cold courtesy. Otherwise the country would have soon become a refuge for criminals and outlaws from the States and an asylum for all sorts of defective and distressed humanity who would have hung like a millstone about the neck of a nation already bowed under the burdens of its own people; and the land hungry pioneers from the very states from which the Cherokees had been expelled would soon have been elbowing the Indian out of his new home just as they had done from the old. In spite of the laws and protests of the Cherokee Council and the "cold shoulder" given them by the Indians themselves, intruders and squatters proved a perpetual nuisance to the country. Washington Irving, in his Tour of the Prairies, ${ }^{4 a}$ gives us a very good description of one of these rough, uncouth, rawboned sons of the frontier, who, with no very clear conception of the distinction between thine and mine, showed scant consideration for the feelings and rights of others in his continual search for more elbow room. When once he had gained a footing it was almost impossible to dislodge him. He and his children were always a demoralizing influence to the Indians, either through lawlessness or intermarriage, for he was often a fugitive from justice in the state from which he hailed and seldom reformed under frontier conditions. His sons and daughters, uneducated and possessing many of the traits of the parent, were not an elevating influence when they became Cherokee citizens by marrying into the tribe, as some of them did. 
Following the example of the south or their own interest and inclination, the Cherokees did not gather into towns and villages to any extent, but formed neighborhood settlements. These settlements were frequently, though not always, composed almost entirely of those related by blood and marriage, for, as has already been said, the clan tie was a strong bond with the Indians and bound them more or less strongly through all their changing fortunes.

One of the most interesting of these neighborhood communities was Park Hill, situated about five miles south of Tahlequah. Here a church and day mission had been started by Dr. Worcester, and a printing press set up, on which various kinds of interesting things were being printed,--tracts, hymns, a primer, the Bible in both Cherokee and Choctaw, ${ }^{5}$ and an almanac computed for the meridian of Fort Gibson containing all sorts of useful information arranged somewhat on the order of Benjamin Franklin's Poor Richard's Almanac, and printed in both the Cherokee and the English languages.

The rich valley to the north of Park Hill commended itself to a number of the emigrants, among whom was Chief Ross. Selecting a site for a home about two miles from the mission station he built a modest little house which he called Rose Cottage. With the arrival of more prosperous days, which, however, were slow in coming, the cottage gave place to a brick mansion furnished with rosewood and mahogany, with silver plate and imported china. The grounds surrounding them were set with shrubbery and choice flowers after the most approved fashion of landscape gardening of the time, while the kitchen garden and the orchard were planned on a scale sufficiently large to supply the demands of the family table, never without guests, and to feed a retinue of house and field servants. A blacksmith shop, a kiln, a laundry, a smokehouse, a dairy, also negro cabins galore were gradually added to the equipment of the estate.

Mr. Ross had married, in 1844, Miss Mary Brain Stapler, a young woman from Wilmington, New Jersey, whom he had met when on a trip east to put some boys in school. She

${ }^{5}$ Missionaries among the Choctaws had succeeded in translating a part of the Bible into that language, and Dr. Worcester was printing it for them. 
was a student in a boarding school at the time and he was a man of more than fifty. It was a case of love at first sight on both sides, and the union, in spite of the disparity of their ages proved to be a very happy one. They lived in rather magnificent style for the time, always keeping open house and frequently giving big dinners. The plantation which came to include a thousand acres or more was worked by slaves and proved to be immensely profitable. It was conducted like all the plantations of the south and everything in the way of food, clothing, and implements used on the plantation was raised or manufactured there. Only the luxuries of the "great house" and its inmates were imported from the outside. Although rumor, with her hundred tongues, spread the belief that such elegance as the chief and his family enjoyed could only have been secured by diverting part of the contents of the national money chest into his private coffers, satisfactory proof of the accusation is entirely lacking.

From the first, slavery became an established institution in the western nation just as it had been in the east. Those who could afford to do so took their servants with them when they emigrated. It was considered an indication of wealth and standing in the community to own negroes, consequently everyone who could afford to do so owned one or more. Chief Ross in 1861 had seventy, and other men of wealth were masters of as many or more.

Missionaries of the old nation had either preceded the emigrants to the west or followed them there. Of the Reverend Cephas Washburn, his mission at Dwight and his work among the Cherokees West, something has already been said. Of those who accompanied the emigrants, Dr. Butler, the Reverend Evans Jones, ${ }^{6}$ and others enjoyed the unbounded confidence of their adopted people. They were men of education and ability who could have filled with credit almost any pulpit in the country. But for the unparalleled services which he rendered the people, the full-blood Cherokees, Dr. S. A. Worcester $^{7}$ stands out a unique figure among missionaries to the

- Couch, Nevada. Pages of Cherokee Indian History.

' Pilling, James C., Bibliography of the Iroquois Languages, pp. 170-175. 
Indians. It will be remembered that he was among the early missionaries in the old country and had shown his loyalty to the Cherokees by willingly suffering imprisonment for championing their cause in Georgia. He was a whole-souled, generous man and a broad-minded, tolerant Christian, proclaiming that not the form of worship but the spirit of it, is pleasing to God; not the making of a solemn vow, but the keeping of it proves one's title to life eternal. Doctor and educator as well as preacher, he was interested in every activity of Cherokee life, seeking to render efficient service wherever he was most needed, eager to bring physical relief to a sick baby, to shed mental light upon the mind of the humblest child, or to preach the gospel of salvation to benighted and sin-cursed men and women. Himself a scholar of no mean ability, his whole training was brought to bear upon the problem of bringing knowledge and Christianity within the range of those who did not understand the English language. In order to do this he planned to prepare textbooks on various subjects in the Cherokee language. At one time he began the arrangement and translation of a geography which he was compelled to give up because it took too much time from his work on the Bible. A grammar and a dictionary, which were in a forward state of preparation when he left Georgia, were lost with all the rest of his effects when the steamboat on which he was going west sank in the Arkansas. Many tracts, pamphlets and some sermons were printed in the Indian language and distributed freely among the full-bloods who read them eagerly.

Upon his release from the penitentiary Dr. Worcester had found his hands tied as long as he stayed in Georgia or Tennessee. Eager to be at his work again he therefore determined to go west just about the time the New Echota Treaty was negotiated. ${ }^{8}$ Unfortunately for him and the cause he was so eager to serve his motives in leaving at this time were misunderstood.

${ }^{8} \mathrm{He}$ was not in favor of the treaty and counseled $\mathrm{Mr}$. Boudinot and others against signing it as long as it was opposed by a majority of the tribe. Drake, Biography and History of the Indians of North America; Couch; Mooney, p. 218; Pilling, Bibliography of the Iroquois Languages, pp. 40-42; Articles, Worcester; the Cherokee Phoenix; Report of Indian Commissioner, for 1843 (Worcester Letters). 
Those who opposed the treaty accused him of deserting their cause, and when they found themselves in power in the west threatened to drive him from the country. This misunderstanding and the untimely death of Mr. Boudinot proved a serious handicap to his work to the end of his long and busy life, which, in spite of hardships and injustice, stands today as an example of what a consecrated mind coupled with a consuming energy may accomplish for education and Christianity. Sequoyah invented for the Cherokees an alphabet, and they proudly and appropriately hail him the Cadmus of their race. Dr. Worcester consecrated that alphabet to the purpose of raising the nation to a higher plane of living and thinking. Yet the name of the Messenger, as he was called, is scarcely mentioned in their fireside history today. The Cherokees are not often chargeable with such lack of appreciation.

Besides Butler, Worcester, and Jones there were other consecrated men and women who preached and taught in the Cherokee country. 'There were also native interpreters and preachers of ability and education. Jesse Bushyhead, Stephen Foreman, William Lasley and John Huss are some of them. These native preachers had the advantage of speaking firsthand to the people, and the eloquence which once thrilled listeners around the council fires, inspiring warriors to valorous action against the enemy, now spoke from the pulpit persuading men to nobler lives and inspiring them to higher purposes and ambitions. Their ability to interpret and explain the Christian religion in terms familar to them through their old pagan faith, tribal customs and even superstititions appealed to the full-blood element who were converted to Christianity as they could have been by no white man, however able and zealous. It is unquestionably due in no small measure to them and their teachings that a Christian spirit dominated the masses of the Cherokees under circumstances which might have rendered God-fearing Anglo Saxons little better than savages. And as a civilizing and educating as well as Christianizing power their influence and that of the missionaries was exceedingly important.

$$
3
$$


There had been no public school system in the old nation for the reason that, just at the time when their national finances might have justified them in starting one, Georgia had extended her laws over the nation putting an end to all hope of progress in that direction. But it will be remembered that a school fund had been provided by the treaty of 1819 , when the proceeds of the sale of a small tract of land in Alabama had been set aside for that purpose. The constitution of 1839 contains this clause: "Religion, morality, and knowledge being necessary to good government, the preservation of liberty, and the happiness of mankind, schools and the means of education shall forever be encouraged in this nation". ${ }^{9}$ The Council three weeks later followed up the constitution by a law providing for a school system to be organized by a board of education composed of three members. ${ }^{10}$ Because of financial straits the school question languished for a time, but in 1841 a law was passed providing for the establishment of eleven primaryschools to be distributed according to population in the various districts. The law also provided for a superintendent of education who should appoint, for each school, a board of directors composed of three members who should hold office on good behavior and whose business it was to locate and superintend the building of school houses, to employ teachers for their respecive schools, to prescribe the kind of textbook to be used and the branches to be taught. ${ }^{11}$ Within five years there were eighteen schools $\mathrm{s}^{12}$ in operation under these laws and an enrollment of six hundred and fifty-five pupils. Thirteen years later they had increased to thirty with an enrollment of fifteen hundred. All but two of the teachers were natives who proved themselves well qualified for their work. ${ }^{13}$ The course of study included

- Art. VI, Sec. 9.

${ }^{10}$ Cong. Doc. 411, No. 1098.

${ }^{11}$ Information furnished by Mr. A. S. Wyley, Commissioner of Education for the Cherokees.

12 The salaries of the teachers averaged forty dollars a month. The school year was divided into two terms of five months each with one month's vacation in winter and one in summer.

${ }^{13}$ Report of the Commissioner of Indian Affairs, 1859, p. 178. 
geography, history and the Testament, in addition to A, B, C, and the "Rule of Three"."

In order to provide their youth with the advantages of a higher education the Council, in 1846, passed a law establishing two seminaries of high school rank, one for boys and one for girls. The former was located in the valley a little more than a mile from the Capitol; the latter, near Park Hill. ${ }^{15}$ The corner stones were laid by Chief Ross on June 17, 1847, and the buildings were finished and ready to be opened three years later. They were two-story brick structures of colonial architecture protected on three sides with wide galleries supported by huge brick columns. Each accommodated about a hundred students who boarded in the institution at a very reasonable price. Especial provision was made for indigent children, so that it was in the power of the poorest girl or boy who had enough ambition and energy to get a very fair education free of cost. Miss Sarah Worcester and Miss Ellen Whitmire, two very superior young women, educated at Mount Holyoke, were engaged as the first teachers at the Park Hill Seminary, and Miss E. Jane Ross, ${ }^{16}$ who had been educated in the east was later added to the faculty.

The course of study included geometry, geography, botany, arithmetic, history, Latin, Greek and such subjects as Watt's Improvement of the Mind, and Paley's Natural Theology and Intellectual Philosophy. ${ }^{17}$ Little attempt was made at industrial education except that each student was assigned by turns to some special duty in the general housekeeping scheme over which a rigid supervision was maintained by members of the faculty. Religious training was not neglected. The Bible was taught daily, while on Sunday religious services were conducted in the institution.

The principal chief himself not infrequently attended the preaching service at the female seminary, his arrival and de-

${ }^{14}$ The report of Mr. James Payne, first Superintendent of Schools of the Cherokee Nation, found in pamphlet report of the Board of Education for 1887 .

${ }^{16}$ From which it took its name, the Park Hill Female Seminary.

${ }^{16}$ A niece of John Ross.

${ }^{17}$ Report of Commissioner of Indian Affairs, 1854, pp. 123-24. 
parture always proving the most interesting and exciting event of the day. His coming, viewed with far more interest than that of the preacher, was heralded by the students through hall and corridor, and groups of eager, bright eyed Indian girls filled every available window and doorway to view the splendid spectacle as the negro coachman drew up the team of blacks at the entrance with a flourish. And when the courtly chief, clad in broadcloth, descended to conduct the first lady of their land, arrayed in rich silks and real lace, into the seminary chapel their pleasure and pride bordered on ecstasy. ${ }^{18}$

The students of the neighboring institutions were no less enthusiastic in their admiration of Chief Ross, and occasionally some of the older boys had the temerity to walk out to Rose Cottage when they knew the chief was at home just for the pleasure and profit of a visit with him. Busy man of affairs as he was, he never denied them an interview, and subjects of interest were discussed as gravely and as courteously with them as business of state with the executive council. And, perhaps not least in importance to the mind of a hearty seminary boy, an invitation to stay to dinner was never neglected nor was it ever declined. ${ }^{19}$

Notwithstanding the fact that the two seminaries were suspended for some time on account of lack of funds, sixty-two young women had graduated from the girls' school before the Civil War, and gone out to teach in the public schools or to take their places as heads of their own households. Perhaps a somewhat smaller number of young men had finished their training at the Male Seminary to take prominent places in politics, education and the ministry. In addition to these young men and women educated at home, a good many sons and daughters of the more well-to-do, sent east by their parents, were carrying off honors at such colleges as Princeton and Mt. Holyoke and coming home to take places of honor and usefulness among their people as doctors, lawyers, law makers and teachers.

${ }^{18}$ Mrs. Eliza Alberty of Tahlequah, Oklahoma, "Aunt Eliza", who was one of these little girls, furnished this description.

${ }^{10}$ Rev. Joe Thompson who was a student at the Male Seminary in these early days has many interesting reminiscences of this time. 
The printing press seized in Georgia had never been returned, nor was it paid for when, in 1843, the Council passed an act authorizing the publication of a paper to be called the Cherokee Adrocate which was to have for its object the information and encouragement of the tribe in agriculture, education, and religion. W. P. Ross, a nephew of the chief, who had graduated at Princeton at the head of his class, was made editor. The first number of the paper appeared in September, 1844 .

Added to the political troubles which distressed the Cherokee Nation in the west there was threatened trouble with the Osages whose title to the western part of the Cherokee Nation had never been satisfactorily adjusted by the Federal Government when it was ceded to the Cherokees. Other wild tribes in the west were restless and discontented for fear of encroachment on their territory. Their menacing attitude at length came to be regarded with no little concern by the Cherokees, and in order to allay uneasiness and establish friendly relations with them they decided to arrange a grand intertribal council where a definite understanding among them all might be reached. Accordingly runners were sent to all the tribes between the Cherokee Nation and the Rocky Mountains inviting them to send deputations to a meeting to be held at Tahlequah in June, 1843.

The invitation met with ready response. At the appointed time chiefs and head men of the Osages, Cheyennes, Kiawas, Comanches, Wichitas and other wild tribes of the plains ${ }^{20}$ together with representatives of the civilized Creeks and Seminoles began to arrive. The meeting proved to be literally a gathering of the clans. Such an assemblage of wild Indians, in all the regalia of war paint and feathers, beaded buckskin and bright hued blankets, with civilized aborigines wearing the conventional costume of the American citizen had never been witnessed before and may never occur again.

The conference lasted ten days, during which time the visitors were given a taste of real Cherokee hospitality. Bar-

${ }^{20}$ Choctaws and Chickasaws were not represented in the meeting. 
becued beef, conutche, ${ }^{21}$ conohany, ${ }^{22}$ "dog ears" ${ }^{23}$ and other Indian substantials and dainties were served bountifully and freely to all. They played Indian games, smoked the peace pipe and listened to the interpretation of the wampum as rendered by the aged Chief Lowrey, the only man then living who understood its mysteries. Finally the various tribes entered into compacts of eternal peace and friendship, which, be it said to their credit, they have never broken. Then, well pleased with their entertainment, themselves and their hosts, they mounted their ponies and in single file rode solemnly back to their people. There was no further rumor of war in the land, nor were Cherokee hunting and trading parties, which frequently made expeditions to the plains, ever molested by Indians. ${ }^{24}$

So strong was his hold upon the full-blood element that Mr. Ross's popularity did not seem to wane as the years went by, even when the government grew to be autocratic and imperial rather than republican and democratic. The principal appointive offices were invariably filled with his personal friends or more often with his own relatives. Charges were made that he was using the chieftainship for personal aggrandizement and private gain and his friends and relatives were profiting by his patronage. There were doubtless some elements of truth in these accusations, but the party of the opposition was never able to prove them to his constituents nor to oust him from his position. Had it been able to do so there is grave doubt whether another man of the tribe before the Civil War had the ability, the training and the experience that would have made him equal to the emergencies that were constantly arising in the nation. Through long years of public life he had not only gained experience and training, but had proved himself resourceful, and systematic in discharging his public duties, diplomatic in his relations with the Federal Government, resolute

${ }^{21} \mathrm{~A}$ drink made by boiling pounded nutmeats.

${ }^{23} \mathrm{~A}$ preparation of Indian corn. ashes.

Made of grated green corn rolled in corn husks and roasted in the

${ }^{24}$ Information on this intertribal council was furnished by D. W. Lipe of Claremore, Oklahoma, who for many years held responsible positions under the Cherokee government and is well informed on all points of their history. Ross, Mrs. W. P., The Life and Times of W. P. Ross. 
and undeviating in pursuing a definite fixed policy of national advancement in politics and education. If he sought to satisfy personal ambitions he also cherished a national pride, and with a broader and far more subtle vision than his fellows, looked to the future, still cherishing the dream of his young manhood to make the Cherokees the greatest nation of civilized Indians. It is doubtless due to this ambition and to his leadership that the tribe did not disintegrate into petty bands soon to fall the prey of land grabbers from the States.

Plagued by droughts which destroyed their crops in 1854 and again four years later, hindered by internal disorders and factional hatred, and embarrassed by the policy of the Federal Government the Cherokees nevertheless made slow, steady progress so that their agent was able to say of them a few months before they were overtaken by the Civil War that: "From their general mode of living the Cherokees will favorably compare with their neighbors in any of the States." population was estimated at twenty-one thousand native Cherokees, one thousand whites and four thousand negroes. They owned large numbers of cattle, hogs, horses and sheep and had in cultivation about one hundred and two thousand acres of land from which they raised abundant crops of wheat, oats and corn when the season was favorable. ${ }^{26}$

The twenty years between 1840 and 1860 form a period of transition when the Cherokees were thrown completely upon their own resources and the help of the missionaries for their development and advancement. But they had at last secured an independent existence and were at liberty to work out, untrammeled by state interference, their tribal salvation. The measure of economic success they achieved in the face of great odds is due to their individual efforts; the credit of their national policy as worked out in the public and high schools and in the government belongs largely to such men of their own tribe as H. D. Reese, Superintendent of Public Schools, William Shorey Coody and the Vanns of whom mention has been made, together with a number of other strong and able men in some of whose veins ran no drop of white blood.

${ }^{25}$ Report of the Commissioner of Indian Affairs, 1859, p. 173.

${ }^{\infty}$ Ibid. 


\section{CHAPTER XIX}

\section{The Civil War}

Before the Cherokees had fairly entered upon the high road to progress and national unity, mutterings of the approaching Civil War began to be heard even in this remote region. The excitement and bitterness involved in the issues of the presidential election of 1860 ran like an electric current throughout the length and breadth of Indian Territory arousing the keenest interest among the entire population within its boundaries, but particularly among the citizens of the five great civilized tribes, the Choctaws, Chickasaws, Creeks, Seminoles and Cherokees. They had all been removed from the southeast under circumstances similar to those under which the Cherokees had been removed. All of them had just emerged from the economic and political chaos into which they had been thrown by removal, and begun to acquire, in the face of the greatest difficulties, many of the arts and much of the science of civilization. They were fairly prosperous, contented and on good terms with the Federal Government whose treaties bound it to protect them from any foreign aggression.

All of the tribes were slaveholders and had borrowed many of their other institutions, both domestic and social, from south of Mason and Dixon's line. Many of their citizens, too, were bound to the South by ties of blood and marriage. All of these influences tended to strengthen the sympathy of the Indians for the South and their interest in the cause of slavery.

Indian superintendents and agents in the Indian Territory had almost all been southern and pro-slavery. Firmly believing in the institution as of divine origin and as an economic blessing to both master and slave they were intolerant of abolition sentiments to the point of forbidding the teaching of them among the Indians. Missionaries and school teachers who were especially zealous in the dissemination of anti-slavery doctrines were summarily sent from the country. One of them, Reverend John B. Jones, a Baptist missionary, who had devoted much of his life to work among the Indians was warned 
by the agent in September, 1860, to leave the country within three weeks because of an article published in a Northern paper stating that he was engaged in promulgating anti-slavery doctrines among his flock. Others were also compelled to leave and the excitement aroused by these incidents continued to increase until the outbreak of the war and the beginning of actual hostilities.

With the excitement incident to the election of 1860 the old factional spirit among the Cherokees blazed up with all its original fervor. Leaders of the Treaty party and the Old Settlers lined up with the pro-slavery people and organized themselves into secret societies called Knights of the Golden Circle, while the loyally inclined members of the tribe combined into an old organization known as the Kituwha, an ancient order revived for the purpose of opposing the pro-slavery adherents, The Kituwahs, who were chiefly full-bloods, came to be called Pin Indians from a pin which they wore as a distinguishing badge in a certain position on the lapel of the coat or hunting shirt. ${ }^{1}$ The Knights drew to themselves the majority of the slaveholders besides the restless element who welcomed any change in the hope of bettering their fortunes, paying off old scores or getting rid of the Ross régime. This lining up of the tribe on the ere of the Great Rebellion into two opposing parties based on long-standing feuds, augured ill for a community which had so recently been restored to a semblance of national unity. The election of Lincoln and the secession of South Carolina were followed by the Cherokee Nation with as keen interest as by any other section in the Union, each faction determined to make the nation serve its interests in the impending conflict.

In the excitement and confusion in Washington during the early months of the struggle the importance to the Union of holding the loyalty of Indian Territory seems to have been underestimated, while the government showed a strange lack of

${ }^{1}$ The Cherokee Question, Pamphlet Report of the Commissioner of Indian Affairs to the President of the United States, June 15, 1866, p. 26; Philadelphia North American, Jan. 24, 1862, Letter of S. W. Butler; Royce, Cherokee Nation of Indians, p. 325. 
conscience towards its treaty obligations to the Indians. With the South it was a different story. From the very outset of the trouble, even before the organization of the Confederacy, preliminary steps were taken to secure the sympathy and cooperation of the tribes of the southwest. Federal agents of the Five Tribes and Elias Rector, the head of the Southern Superintendency, began in the early winter to take an active part in fortifying the minds of the Indians against the incoming administration and arousing sympathy for the southern cause. Douglas M. Cooper, agent of the Choctaws and Chickasaws and an appointee of Buchanan, took advantage of the remoteness of his situation to work openly for secession.

As a result the Chickasaw legislature on January 5 went so far as to call an intertribal council should a political separation between the North and the South take place. ${ }^{2}$ The suggestion met with favor from all the Five Tribes except the Cherokees. Chief Ross objected to the plan on the ground that the controversy between the North and South was strictly a white man's quarrel and no concern of the Indians. He was overruled, however, and a council was called for February 17. The Choctaw Council, influenced by Cooper, without waiting to see what its neighbors would do, came out boldly on February 7 for the Confederacy on the ground that their national affections, education and interests bound them indissolubly in every way to the destiny of their neighbors of the South. ${ }^{3}$ When the intertribal council met ten days later at the Creek Agency neither the Choctaws nor Chickasaws were represented. The Cherokee, Creek and Seminole delegations discussed the situation at length and arrived at the conclusion to simply do nothing; to keep quiet and comply with their treaty obligations. Mutual expressions of good feeling were given and promises exchanged that whatever exigencies of the future might arise, bound by a common destiny, they would act in concert for the greatest good to all."

${ }^{2}$ Official Records of the War of the Rebellion, Series I, Vol. I, p. 682; Abel, The Cherokees in the Civil War, American Historical Review, Vol. $\mathrm{XV}$, p. 282.

${ }^{3}$ Ibid. This was the very day the southern Senators in Washington adopted resolutions advising secession.

- Ibid; Abel, A. H. 
This action of the Indian tribes was watched with the keenest interest by Arkansas, no part of the South being more vitally concerned in their attitude at this crisis. The Cherokee and Choctaw Nations hemmed in her whole western border, even encroaching, in the opinion of that state, upon her rightful domain. The action of the Choctaws had been gratifying. Coöperation of the Cherokees must be secured at all hazards.

More than three months before the state seceded, Governor Rector wrote Chief Ross a very ingratiating letter calling attention to the fact that the Cherokees in their institutions, productions, latitude and natural sympathies were allied to the common brotherhood of slaveholding states, and assuring him that it was an established fact that the Indian country was looked upon by the incoming administration "as a fruitful field ripe for the harvest of Abolitionists, free-soilers and northern mountebanks". He promised to give the Cherokees protection in their exposed condition and to assume the monetary obligations of the Federal Government to them if they would join the South in the defense of her firesides, her honor, and her institutions. ${ }^{5}$

Mr. Ross replied in a masterly letter expressing the regret and the solicitude of the Cherokees for the unhappy relations existing between the two sections of the country and hoping for the restoration of peace and harmony, at the same time declaring, in no uncertain terms, the loyalty of his people to the Federal Government. The Cherokees, he reasoned, had placed themselves under the protection of the United States and were bound to enter into no treaty with any foreign power, neither with any individual nor citizen of any state. The faith of the United States was solemnly pledged to protect them in their land titles and all their individual rights and interests of person and property. The Cherokees were inviolably allied with the United States in war and were friends in peace. While their institutions, locality and natural sympathy were unequivocally with the slaveholding states and the social and commercial intercourse between the Cherokee Nation and Arkansas

'Official Records of the Rebellion, Series 1, Vol. 13, pp. 490-92; Vol. 1, p. 683; also, Moore's Rebellion Records, Vol. 2, Doc. 114. 
were of great importance to his people these interests must be subordinated to the higher one of his nation's honor. ${ }^{6}$

Not satisfied, with this reply, citizens of western Arkansas and the commandant at Fort Smith brought strong pressure to bear upon the chief demanding to know on what ground he stood, as they preferred an open enemy to a doubtful friend. ${ }^{7}$ To them he replied that the Cherokees would take no part in the trouble. Weak, defenseless and scattered over a large section of country in the pursuit of agricultural life, without hostility to any state, and with friendly feeling to all, they hoped to be allowed to remain neutral, for persons so gallantly tenacious of their own rights would respect those of others. Being fully aware of the defenseless condition of the Cherokees their friends would surely not expect them to destroy their national and individual rights and bring around their hearthstones the horrors and desolation of a civil war prematurely and unnecessarily. "I am-the Cherokees are your friends" he assured them, "but we do not wish to be brought into the feud between yourselves and your northern brethren. Our wish is for peace-peace with you and peace at home"8 But the old chief was crying "peace, peace!" when there was no peace.

The Confederate Provisional Congress, doubtless urged on by Arkansas and Texas, and appreciating the strategic position of Indian Territory in relation to Colorado and Kansas and its importance as a source of food supply, ${ }^{9}$ created a Bureau of Indian Affairs as early as the middle of March, with an appropriation of $\$ 5,000$ for its support, and attached it to the War Department. David L. Hubbard of Alabama was placed at the head with instruction to repair immediately to the Indian country where he would make known to all the tribes the desire of the Confederate states to protect and defend them against the rapacious and avaricious designs of their

- Official Records of the Rebellion, Series 1, Vol. 1, p. 683; Moore's Rebellion Records, Vol. 2, p. 392.

"Moore's Rebellion Records, Vol. 2, p. 393.

${ }^{8}$ Ibid, pp. 393-4.

- Official Records of the Rebellion, Series I, Vol. 8, p. 697. 
common enemy whose real intention was to emancipate their slaves and rob them of their lands. ${ }^{10}$

Illness prevented Mr. Hubbard from carrying out his intention of going in person to the Indian Territory but he wrote to Chief Ross, and in addition to his instructions reminded him that nearly all the funds of the Cherokees, representing their annuities and school funds, were invested in southern securities which debts were already forfeited unless the Cherokees joined the Confederacy.

To this Chief Ross replied in most dignified and courteous language, repeating his reasons for holding a position of neutrality, and assuring Mr. Hubbard that, if the institutions, locality and long years of neighborly deportment and intercourse did not suffice to assure him of the friendship of the Cherokees no mere instrument of mere parchment could do so. "We have no cause to doubt the entire good faith with which you would treat the Cherokee people, but neither have we any cause to make war against the United States, or to believe that our treaties will not be fulfilled and respected. At all events a decent regard to good faith demands that we should not be the first to violate them." It was not the business of the Cherokees, he thought, to determine the character of the conflict going on in the states. It was their duty to keep themselves free from entanglements and afford no ground to either party to interfere with their rights.

As to the question of whether the Cherokees would receive kinder treatment at the hands of the South than could be expected from the North, he remarked significantly, that the settled policy of acquiring Indian lands had always been a favorite one with both sections, and but few Indians north or south pressed their feet upon the soil of their fathers. ${ }^{11}$

Meanwhile two events had taken place destined to have important bearing upon Cherokee neutrality. In April all the Federal troops were withdrawn from Indian Territory and it was immediately occupied by the Confederacy and formed into the Military District of Indian Territory, with the brave Texas

${ }^{10}$ Official Records of the Rebellion, Series I, Vol. 3, p. 577.

${ }^{11}$ Ibid, Vol. 13, 499. 
Ranger, Benjamin F. McCulloch, in command. With a regiment from each of the states, Arkansas, Louisiana and Texas, and with instructions to raise additional regiments among the Five Tribes to be attached to his command, he prepared to establish headquarters at some suitable place in the Cherokee Nation. ${ }^{12}$

The Knights of the Golden Circle, in full sympathy with the plan, decided that the time was ripe for them to lend a hand. Realizing the weakness of their numbers they determined upon a strategic move to raise the rebel flag over the capitol at Tahlequah, guarding their intentions with the greatest secrecy. ${ }^{13}$ Great was their discomfiture, therefore, when they arrived on the appointed day to find the flinty streets of the little town filled with stonier faced full-bloods, gathered from all parts of the Cherokee Nation for the purpose of checkmating them.

Baffled and outwitted and fearing violence from the determined Kituwhas the Knights posted a messenger after Mr. Ross at Park Hill, who was ignorant of what was on foot five miles away. Accompanied by Mrs. Ross, a loyal Union sympathizer, he hastened to the scene of action. There the Knights plied him with arguments and persuasions, but all to no effect. The people presently dispersed quietly to their homes, ${ }^{14}$ but not to the waving of the "Stars and Bars", nor to the music of the "Bonnie Blue Flag".

Chief Ross, fearing the demoralizing effect upon the tribe of the Tahlequah incident and the plan for establishing Confederate headquarters in the Cherokee Nation, issued a proclamation, on May 17, counseling the people to cultivate peace and harmony among themselves and to observe in good faith strict neutrality towards the states threatening Civil War. ${ }^{15}$

Disappointed in the failure of the Knights and finding his own scheme firmly opposed by Chief Ross, whom he was as yet unwilling to antagonize, General McCulloch changed his plans

${ }^{12}$ Abel, The Indians in the Civil War, p. 284.

${ }^{13}$ Letter of S. W. Butler, Philadelphia North American, Jan. 24, 1863.

${ }^{14}$ Ibid. The Cherokee Question, p. 26; Royce, The Cherokee Nation of Indians, p. 325.

${ }^{15}$ Official Records of the Rebellion, Series I, Vol. 13, p. 489. 
and began mustering his forces at Fort Smith, just over the Arkansas line. ${ }^{18}$ Determined, however, that the Cherokees should eventually fight with the Confederacy, he was only biding his time.

It was at this period in the crisis that the picturesque figure of Albert Pike appeared upon the Indian horizon. He was a Bostonian by birth, had studied law at Harvard and taught school in New England. Responding to the call of the west in early manhood he joined Bent's expedition to Santa Fe in 1832 and spent a few months in New Mexico. Returning by way of Fort Smith he determined to settle in Arkansas. Here he taught school, practiced law and engaged in literary pursuits. Acquaintance with the Indians aroused a genuine interest in the wrongs they had suffered at the hands of his own race, and he became the avowed friend and advocate of the red man. When the Civil War broke out he declared for secession and offered his services to the Confederacy in effecting alliance with the tribes of the southwest. ${ }^{17}$ The Confederacy promptly recognized that there were none better fitted for this task by commissioning him to negotiate treaties of friendship and alliance with the nations of Indian Territory.

As his mission was one that required promptness he set out at once, stopping on the way for an interview with General McCulloch at Fort Smith. Here a party of Cherokees representing the Knights of the Golden Circle called upon him to find out whether the Confederate states would protect them against Mr. Ross and the Pin Indians if they should organize and take up arms for the South. ${ }^{18}$

He assured them of Confederate protection and arranged a meeting with them and their friends at the Creek Agency two days after a conference which he expected to have with Chief Ross and General McCulloch at Park Hill. ${ }^{19}$ Attended by a mounted escort in all the splendor of uniform and military trappings he then set out for Indian Territory. As the caval-

${ }^{18}$ Snead, The Fight for Missouri, p. 230.

${ }^{17}$ Official Records of the Rebellion, Series I, Vol. 2, pp. 580-581; Abel, Indians in the Civil War, p. 285.

${ }^{18}$ The Cherokes Question, p. 26.

10 Ibid. 
cade swept down the Line Road to Evansville and on towards the Cherokee capital its magnificent appearance was well designed to impress the simple natives with the greatness of the government which it represented. There are men and women still living who remember the occasion as one of the most interesting and dramatic episodes of the war in that part of the country.

Arriving at Park Hill somewhat in advance of his attendants, General Pike was received by the chief with his accustomed hospitality and irreproachable courtesy. Here General McCulloch presently joined him and negotiations for a treaty of alliance were formally opened. Chief Ross took a firm stand, repeating his determination to remain neutral and his argument that it would be a cruel thing for the Confederacy to force a weak and defenseless people into a quarrel not their own. While frankly admitting that all their sentiments and feelings were on the side of the South he declared that he could not permit his people to become involved in any way if he could prevent it. They were unable to shake the purpose of the old Chief by force of argument or diplomatic strategy, and the conference came to a close with the promise of General McCulloch to respect the neutrality of the Cherokees and to refrain from placing troops in their nation unless it became necessary in order to expel a Federal force or to protect the Southern Cherokees. $^{20}$

Perhaps General McCulloch made the promise in good faith. A few days later he wrote Mr. Ross again assuring him of his intention of respecting the agreement of neutrality, but now insisting that all Cherokees who were in favor of joining the Confederacy should be allowed to organize into military companies as Home Guards for the purpose of defending themselves in case of an invasion from the North. ${ }^{21}$

Mr. Ross, too keen to be drawn into a scheme which would virtually commit him to the Confederacy without any of the advantages of a formal treaty, replied that he could not give his consent to such a plan. It would not only violate Cherokee

${ }^{20}$ The Cherokee Question, p. 26.

${ }^{21}$ Official Records of the Rebellion, Series I, Vol. 3, p. 592. 
neutrality but would place in their midst a band of organized and armed men not authorized by Cherokee laws and not amenable to them. ${ }^{22}$

Out of patience with what he considered the irritating obstinancy of Mr. Ross, General McCulloch began collecting troops at Sculleyville, in the northern part of the Choctaw Nation near the Cherokee line, with the avowed purpose of intimidating the loyal Cherokees and forcing Chief Ross into abandoning his position of neutralty.

General Pike on leaving Park Hill pressed on to the Creek Agency where he had expected to meet and arrange terms with the southern faction of the Cherokees. To his disappointment they failed to appear ${ }^{23}$ and he passed on to the west where he busied himself in arranging treaties with the Choctaw and Chickasaw Nations and with various bands of western Indians. The former, after signing treaties, availed themselves of the privilege of sending delegates to Richmond, and issued a proclamation to the neighboring nations urging them to form an alliance, offensive and defensive, against Lincoln's hordes and Kansas robbers." ${ }^{24}$

As the Confederate Commissioner made his way westward arranging treaties with the Indians, and as the marshaling of forces on the borders went foward with vigor, the position of the Cherokees grew daily more precarious. The Creeks and the majority of the Seminoles still remained faithful to their agreement of the previous winter, but the Federal Government showed no intention of sending them relief and protection.

Realizing that something must be done quickly, Chief Ross, with the support of Hopothleyohola, leader of the loyal Creeks, sent out a call for an intertribal council to be held near Antelope Hills, in the extreme western part of Indian Territory. The purpose was to weld the western tribes into an independent Indian Confederacy with strength enough to command respectful attention from both sections before General

${ }^{22}$ Ibid, pp. 596-7.

${ }^{23}$ Afterwards they gave as their reason the fear that they would be murdered by the Ross party if they openly sided with the South. The Cherokee Question, p. 25.

* Official Records of the Rebellion, Series I, Vol. 13, pp. 585-7. 
Pike could arrange treaties with them. The Council was held and the representatives entered willingly into the proposed compact, but the ultimate purpose of the plan was defeated by General Pike, who, having received intimation of it, succeeded in securing an agreement with a faction of the Creeks while their representatives were in council at Antelope Hills. ${ }^{25}$

The failure of the Indian Confederacy, the neglect of the loyal Indians by the Federal Government and the concentration of Confederate forces on their border had caused the loyal Cherokees keen disappointment and alarm. Then came news of the Battle of Wilson Creek, with an exaggerated account of the discomfiture of Union forces. McCulloch's army was marched back to the borders of the Cherokee Nation and the Cherokees were compelled to decide promptly whether they would take up arms for the North or the South.

Faced with this situation Chief Ross called his Council together August 21, 1861, for the purpose of taking into consideration the question of the difficulties and dangers surrounding their nation and to determine the most available method of procedure. As it was a question of vital interest to the whole tribe a call was sent summoning everyone to a conference at Tahlequah. The situation was so critical and the tension of feeling so highly strung that a large per cent of the voting population responded. On the appointed day about four thousand Cherokee men were assembled on the capitol square. The southern party, seeing their opportunity, and encouraged by citizens of Arkansas, turned out in full force and full arms. By their firmness of speech and domineering manner they awed into silence and nonresistance any spirit of neutrality which yet manifested itself. Agent Crawford took a prominent part in the meeting, painting in glowing colors, the advantages of secession to the tribe. ${ }^{26}$

Chief Ross in his message to the Council, after having justified his previous policy of neutrality on the ground of good faith and expediency, declared that the Cherokees had at last come to the parting of the ways. Neutrality was no longer

${ }^{25}$ The Cherokee Question, p. 27. Royce, The Cherokee Nation of Indians, p. 327.

${ }^{20}$ Abel, The Indians in the Civil War, p. 288. 
possible. Since they had been deserted by the Federal Government they owed no further allegiance to it. There was no longer any reason to doubt that the Union was dissolved: there was likewise no cause for hesitation as to the course the tribe should pursue: their geographical position and domestic institutions allied them, unquestionably, to the South. ${ }^{27}$

It has been charged that the chief was forced into this change of sentiment in much the same way the stamp distributors of 1765 were compelled to stand before the rabble and shout "liberty, property and no stamps:" that part of his speech in the excitement and heat of the moment was misconstrued either intentionally or unintentionally, and that what he intended for a noncommital, pacifying address was reported as a fiery denunciation of the Union.

That he had just cause to denounce the treatment his people had received and were receiving from the Union there is no question of a doubt, but there are so many conflicting versions of the story even today by those who participated in the meeting, and the documents contain such contradictory statements that a positive conclusion of what he really said and did is not easily reached. ${ }^{28}$ At any rate the convention unanimously adopted a resolution to abandon the relations with the Federal Government and to form an alliance with the Confederacy if the latter would guarantee to them the payment of an amount equal to their invested funds.

A messenger was forthwith dispatched to General Pike to apprise him of the action of the Council and to invite him to return to the Cherokee Nation for the purpose of arranging a treaty with their government. He was met at Fort Gibson by Colonel Drew's regiment of home guards composed chiefly of full-bloods and Pins, which had been raised by order of the National Council, and conducted with some ceremony to Park Hill, where a treaty was arranged.

${ }^{27}$ Official Records of the Rebellion, Series I, Vol. 13, p. 501. This is the report of a message delivered to the Council October 9, in which is given a summary of his message of August 21.

${ }^{28}$ The Cherokee Question, Various reports and letters; The Ross correspondence; The Proceedings of the Cherokee National Council for 1863; Cong. Doc. 1232, No. 52. 
The third article of the treaty states that the Confederate States, having accepted a protectorate over the Cherokee Nation, solemnly promised never to abandon or desert it, and that under no circumstances would they permit the Northern States or any other enemy to overcome them and sever the Cherokee from the Confederacy, but that they would, at any cost, and all hazards protect and defend them and maintain unbroken the ties created by identity of interests and institutions, and strengthened and made perpetual by this treaty. The Confederate states bound themselves to pay the Cherokees the sum of $\$ 250,000$ on the ratification of the treaty, to continue the annuities they had formerly received from the United States and to indemnify them for all losses that they might suffer as a result of abrogating their treaties with the United States. On the other hand, the Cherokees agreed to furnish all their able-bodied men to the Confederate States for military service against the United States, with the stipulation that their forces should not be required to march outside of their own country without their consent. ${ }^{29}$

On the same day the Cherokee treaty was negotiated, representatives of the Osages, Senecas, Quapaws, and Shawnees, by invitation of Chief Ross, met General Pike at Park Hill, where they also arranged treaties of alliance with the Confederacy. Afterwards they held a conference with Mr. Ross at his residence, smoked the great peace pipe and renewed their agreements of eternal peace and friendship. ${ }^{30}$

Although the Cherokees had severed their relations with the Federal Government very reluctantly they immediately began preparations to maintain their new alliance. The regiment of Home Guards under Colonel John Drew was now placed at the services of the Confederacy, and a second regiment recruited and placed under the command of Colonel Stand Watie. Chief Ross entered heartily and enthusiastically into the spirit of the preparations, entertaining high hopes that all factional differences would disappear and that his people would become united once more when they joined forces to

${ }^{20}$ Confederate Statutes at Large, pp. 394-411.

${ }^{2}$ The Cherokee Question, p. 28. 
repel a common enemy. Just after the signing of the Confederate treaty he had given his hand to Stand Watie as an expression of his desire to heal the old breach, and Watie had accepted it in all courtesy and good faith. No one realized more clearly than the old chief that the cost of war would be dear to his people at any price. Yet, if the Cherokees could emerge from the smoke of battle a united nation, the struggle would not have been without its compensations. 


\section{CHAPTER XX}

\section{The Civil War, Concluded}

As the Cherokees were the first to violate the compact of neutrality entered into with other tribes at the Creek Agency in February and at the Antelope Hills Conference some months later, natural courtesy and a due regard to the good will of their neighbors rendered necessary an explanation of their changed attitude, consequently Chief Ross sent a circular letter to the various tribes explaining the causes which impelled the Cherokee Nation to join the Confederacy. ${ }^{1}$ He even went so far as to suggest the desirability of a union of all the Red Brethren with the Richmond government. One of these letters was dispatched to Hopothleyohola, who had been a very good friend of the Cherokee chief and had supported him loyally in his stand for neutrality. The letter was returned, with a note written across the back, asking if Mr. Ross were really the author of it. ${ }^{2}$

This sharp thrust at Cherokee constancy was not lost upon the keen witted and diplomatic Chief Ross who immediately sent a special delegation, headed by Joseph Vann, the second chief of the nation, on a mission of peace to the Creeks to explain more fully the position of the Cherokees and to invite their chiefs to visit the Cherokee Council then in session. ${ }^{3}$ But Hopothleyohola would have nothing to do with them. They had broken a compact and were not to be trusted again. $\mathrm{He}$ would go his way and they were free to go theirs. His mind was made up, for reasons of his own, to remain loyal to the Union.

With two-thirds of his tribe in war paint and fighting gear he was preparing to defend its interests in the Creek Nation at all costs. Not that the old Creek chief was actuated by such motives as inspired Webster's immortal words, "liberty and Union, now and forever, one and inseparable." In fact he

${ }^{1}$ The Cherokee Question, p. 20, the Correspondence between Chief Ross and Hopothleyohola is found in full, pp. 16-20.

2 Ibid, p. 17.

${ }^{3}$ Ibid. 
did not understand American patriotism. How could he, or the members of his tribe or of any of the Indian tribes? Indian Territory was not an integral part of the Union as was 'Texas or Arkansas, but was practically a foreign dependent ally. Its citizens were a people apart from the Federal Government with a patriotism all their own, which took no cognizance of such common bonds of interest as the celebration of Thanksgiving and the Declaration of Independence. He had a grudge to pay and this occasion furnished the opportunity. And who can criticise the chief of a recently barbarous tribe for going to war with such an incentive when, if the truth were told, half of the white men on both sides in the conflict were actuated by no higher motives? If this fact of the relation of the Indians to the Federal Government is kept clearly in mind, along with some others which must linger in the memory of all who have read the preceding pages of this story, it will be less difficult to understand why Indian loyalty was likely to shift from time to time with the changing fortunes of war.

But Hopothleyohola was not one to waver in his allegiance. With an armed force he made a raid upon his former friends, the Cherokees, driving off stock and wantonly destroying other property. ${ }^{4}$ Then marshaling his forces in the Creek Nation, he prepared to stand his ground against an overwhelmingly superior number of Choctaws, Chickasaws, Seminoles and Cherokees under Colonel Cooper. A stronghold was chosen and intrenchments thrown up in a bend of the Bird Creek about twelve miles north of Tulsey town. ${ }^{5}$ This, Cooper prepared to attack in December.

On the eve of battle the Cherokee troops under Colonel Drew deserted in a body, swearing that they would willingly shoot Yankees, but when it came to fighting their old friends and neighbors, the Creeks, they drew the line. Cooper, with his remaining forces, attacked the Creeks and easily defeated them, driving them into the hills beyond. Still pursuing them, he finally pushed them northward beyond the Kansas line, fol-

${ }^{4}$ Official Records of the Rebellion, Series I, Vol. 8, p. 209. bends.

${ }^{5}$ Now Tulsa. The Creeks seem to have had a weakness for horseshoe 
lowed by a straggling train of helpless women and children. ${ }^{6}$

The winter of 1861-2 was a bitter one for these Indian refugees. Loyal bands from the Five Tribes, together with detachments from other tribes kept arriving, until the aggregate numbered over six thousand, camped along the southern border of the state. Shelterless, half naked, barefooted and nearly starved, they presented a sorry sight. ${ }^{7}$ All attempt of the Federal authorities to relieve them resulted only in furnishing opportunity for peculation to Government agents and state politicians who shamelessly feathered their own nests at the expense of shivering, shelterless and starving women and children. There seemed no way of relieving the situation as long as the Indians remained in Kansas. The only hope of relief lay in their return to Indian Territory, now occupied by Confederate troops. Before the Indians could return in safety the country would have to be cleared of the enemy and reoccupied by Federal forces, which were so urgently needed in other quarters just at this time. ${ }^{8}$

This was the situation when Senator Lane, the originator of the "homeward bound" movement, went to Washington in January, 1862, and there so convincingly presented the cause of still "Bleeding Kansas" and of the Indian refugees, that he was given permission to organize an expedition at once to carry out his purpose. ${ }^{9}$ Owing to petty jealousies and to the spirit of insubordination, if not rank duplicity, on Lane's part, to gain his ends, the expedition soon fell into disrepute as "Lane's jay hawking expedition." The project was thus delayed from month to month until a petty game of personal ambition and state politics could be played out, the Indians, meanwhile, dying of starvation and exposure.

While political intrigues and petty jealousies were sacrificing the Union Indians in Kansas, General Curtis was marching his troops across Missouri for the purpose of avenging

' Official Records of the Rebellion, Series I, Vol. 8, pp. 712, 715; also, pp. 4-33.

${ }^{7}$ Report of Commissioner of Indian Affairs, 1862, 1863; Abel, The Indians in the Civil War, p. 289.

8 Ibid.

- Official Records of the Rebellion, Series I, Vol. 8, p. 525. 
Lyon and Wilson Creek, and of recovering Federal forts in Arkansas. The Confederate forces west of the Mississippi in command of Major General Earl Van Dorn werc concentrated in northwest Arkansas to oppose him. They consisted of Sterling Price's volunteer troops, chiefly from Missouri, McCulloch's regulars, and several regiments of Indians under General Albert Pike. ${ }^{10}$ The opposing armies met near Fayetteville, Arkansas, early in $\mathrm{March}^{11}$ and two engagements took place at Pea Ridge and Elk Horn Tavern. The result was a defeat for the Confederacy, due in part to a lack of coöperation among commanding generals. Both were bioody battles in which Indians on one side were pitted against Germans on the other.

Deeds of revolting barbarism were perpetrated upon the dead and dying by the scalping knife, sword and bayonet. 'The country at large was horrified to hear that the first scratch of battle had revealed the savage under the epidermis of the most cultured and civilized Red Skin, and jumped to the conclusion that all Indians employed in the engagement had reverted to their primitive customs in warfare. ${ }^{2}$ The truth is certainly bad enough to need no exaggeration. As a matter of fact eight scalped heads were counted on the battle field after the fight was over. ${ }^{13}$ There was perhaps a greater number of mutilated bodies of Confederate dead. 'The scalps, without doubt, were counted as trophies by Indian braves who had not yet learned that such unrefined methods of killing their fellow men were not to be countenanced in civilized warfare. Their own people, deeply mortified over the offense, condemned it severely, but were unable to locate the offenders for punishment. ${ }^{14}$

The trail of blood from the mutilated bodies of southern soldiers, however, leads in quite another direction until it stops

${ }^{10}$ After completing his work of negotiating Indian treaties, Pike was made "Commander of all the Indian troops in the Confederate service." Official Records of the Rebellion, Series I, Vol. 8, p. 690.

${ }^{11}$ March 6-8.

${ }^{12}$ Official Records of the Rebellion, Series I, Vol. 8, p. 235.

${ }^{13}$ Ibid, pp. 195, 207, 236.

${ }^{14}$ John Ross to Albert Pike, Ross Mss. Information also furnished by several Cherokee men who fought in the Civil War. 
at the door of a band of men whose ancestors on the banks of the Rhine had been undergoing the process of civilization ever since the time of Charlemagne, or before. ${ }^{15}$ Thus it would seem that, under the savage influence of war, the power of atavism is as strong after a thousand years of evolution as after a hundred. Be that as it may, the Cherokees rendered splendid service in the battle of Pea Ridge in spite of the contempt in which they were held by the commanding general.

After these defeats the white troops were drawn off towards the east where they were needed to stay the march of the Union army steadily advancing southward down the eastern Mississippi Valley. Colonel Drew's regiment went into camp at the mouth of the Illinois River in the Cherokee Nation. Colonel Watie was sent on a raiding expedition into southwest Missouri and General Pike established headquarters in the southwestern corner of the Choctaw Nation, ${ }^{16}$ at Fort McCulloch.

At length, after various delays, the Lane expedition had been organized and was ready to march into Indian Territory. Leaving Humbolt, Kansas, the latter part of June it crossed the southern border of the state five thousand strong. The advance guard was led by General Weer, who, upon entering the Indian country, offered to open negotiations with the Cherokees to return to their former alliance. Through Chief Ross they courteously declined the offer, saying that a treaty of alliance had already been entered into with the Confederacy, the reasons for which were too well known to Colonel Weer for it to be necessary to recapitulate them. ${ }^{17}$

The country was now in a defenseless condition and a letter was sent post haste to General Hindman, who had been placed in command of the Trans-Mississippi District on the death of McCulloch at Pea Ridge, calling on him for protection against the invading army. The commanding general at once ordered General Pike northward to join the Cherokee regiments in the vicinity of Fort Gibson. Pike, whose forces were poorly equipped to meet the enemy, for reasons which will appear later,

${ }^{15}$ Official Records of the Rebellion, Series I, Vol. 8, pp. 195, 482.

${ }^{16}$ Near Armstrong Academy.

${ }^{17}$ Moore's Rebellion Records, Vol. 5, pp. 549-550. 
sulked in his tent, ignoring the order. After it had been peremptorily repeated several times he resigned, and Douglas $\mathbf{M}$. Cooper was put in command. Cooper moved northward promptly but too late to prevent a Confederate defeat at Locust Grove, about thirty miles north of Tahlequah. Here a small command composed of the Cherokee troops under Colonel Watie and Colonel Drew and a battalion of Missourians under Clarkson, offered a brave resistance to the Kansas forces, who outnumbered them two to one. Clarkson's whole train was captured and Drew's regiment ${ }^{18}$ deserted to the enemy. Colonel Watie's troops fought with great bravery but were finally forced to give way to superior numbers. ${ }^{19}$

An explanation of Drew's conduct, as well as Pike's, is to be found in a declaration of General Pike to the Five Tribes bearing the date of July 31, 1861. It states that their cause had been betrayed by the Confederacy, that they themselves, in violation of their treaties, had been taken out of their country and forced to serve beyond its boundaries, yet without their due measure of credit; that they had been despised and criticised by the white troops; that they had been kept in Arkansas while their own country was being exposed to hordes of jay hawkers, and that they were permitted to go to its defense only when the enemy's forces had reached such proportions that their own unaided strength was unable to withstand it, yet no appreciable number of white troops had been sent to their assistance. ${ }^{20}$ In addition to these charges the supply of clothing and ammunition intended for the Indian troops had been stopped at Little Rock or Fort Smith and directed into other channels so that their soldiers were illy clad and poorly equipped. They remained unpaid from month to month causing unrest and dissatisfaction throughout Indian Territory. In addition to these causes the old factional jealousies among the Cherokees had been aggravated by the greater appreciation shown by the Confederate Government for

${ }^{18}$ With the exception of a small number of men under Capt. Pickens.

${ }^{10}$ Official Records of the Rebellion, Series I, Vol. 12, p. 40.

2 Ibid, Vol. 13, pp. 869-871. 
Colonel Watie's troops who had won the reputation of being better soldiers than Drew's full-bloods.

After the engagement at Locust Grove, General Weer moved his army southward in two detachments and established headquarters on the Grand River ${ }^{21}$ about fourteen miles north of Fort Gibson. On July 14, Major Campbell entered the Confederate stronghold and the same day Captain Green arrived at Tahlequah. The following day the latter moved his command to Park Hill where he found about two hundred Cherokees awaiting an opportunity to join the Union. Colonel W. P. Ross and Major Thomas Pegg, who were at Mr. Ross's house debating whether they should respond to an order just received from Colonel Cooper to report for duty at Fort Davis, were arrested and sent to headquarters.

The war clouds were now gathering thick and fast about the gray haired chief of the Cherokees. A few days before the arrival of the Union forces Colonel Cooper, in the name of President Davis, had commanded him to issue a proclamation calling on every able-bodied Cherokee man between the ages of eighteen and thirty-five to enlist in the Confederate military service. Following on the heels of this demand, and probably caused by it, the Pins rose in rebellion and compelled their chief, at the end of a halter, to declare for neutrality. Compliance with the demand meant death at the hands of his own people. To ignore it was to put himself at the mercy of Colonel Cooper. While he was thus hesitating between the devil and the deep sea, the question was settled for him by Captain Gaino, who arrested and placed him on parole, thereby adding to the complication and confusion.

With the Confederate army in retreat, the Federal army in control and his own government in anarchy, he found himself again face to face with a crisis which he had to meet quickly. The Confederacy had proved itself no more faithful to treaty relations than the Federal Government had done. Good faith no longer bound him. Expediency pointed to a renewal of relations with the north. Worn out and sick at heart over the hopelessness and confusion of the whole situation,

${ }^{21}$ Across the river from Fort Gibson and near Muskogee. 
he determined to return to his allegiance to the Union while there was yet a shadow of hope to save himself and his nation from utter annihilation. When General Weer again approached him on the subject, he yielded. As the Cherokee Nation was no longer a safe place for him he accepted the offer of a Union escort to Fort Gibson. With his family and what valuables ${ }^{22}$ could be loaded onto two ox wagons he left the country, making his way by Fort Scott, Kansas, to Philadelphia.

The success of the first Union invasion proved temporary. At this time a small, well organized force could have held the country easily, but inefficiency and lack of harmony among the commanding officers ${ }^{23}$ led to mutiny and insubordination on the part of the soldiers. Delay resulted, giving the Confederate Indians under Cooper and Stand Watie time to join forces with white troops under General Raines. When these combined commands moved northward the Union army retreated towards Kansas, leaving the Cherokee country in the hands of the Confederacy again. Tahlequah was recaptured. The victorious southern Cherokees held a convention and passed ressolutions deposing Chief John Ross from office. Stand Watie, now a military hero, was elected to succeed him.

Had the triumphant army been content to enjoy the fruits of its victory with moderation and mercy there would be one less series of disgraceful tales to tell of the Civil War. Unfortunately that was not the case. Summary vengeance was wreaked upon the families of loyal Cherokees, their long-standing enemies. Women, children and old men, driven out of doors at midnight, were forced to seek protection by following the trail of the retreating army by the light of their burning homesteads. Beautiful Rose Cottage, after it had been sacked and denuded of whatever valuables could be carried away, was given to the flames.

The success of the Confederate army was short-lived. In a few weeks the Federal forces, having rallied for a second

${ }^{22}$ Including all there was left in the National Treasury.

${ }^{23}$ Colonel Weer was arrested by Colonel Solomen on the charge of drunkenness and foolhardiness in cutting off communications from the base of supplies. 
invasion of Indian Territory, marched back across the Kansas line, this time under command of Brigadier James G. Blunt, who defeated Cooper at Fort Wayne, and with the assistance of Colonel W. A. Phillips drove the Confederate army south of the Arkansas River. Fort Gibson was retaken and from now on to the end of the war remained the base of Union activity in Indian Territory.

When the fortunes of war had again wrested the greater part of the Cherokee Nation from the hands of the Confederate forces and it was apparent that the Northern army had come to stay, the loyal Cherokees met in Council at Camp John Ross in February, 1863, Thomas Pegg acting as principal chief. They repudiated the alliance with the Confederate states, restored their allegiance to the Union, abolished slavery and involuntary servitude in the Cherokee Nation and passed a law confiscating the property of all Cherokee citizens who were enemies of the Union. Mr. Ross was reinstated as principal chief. ${ }^{24}$

The war dragged on in Indian Territory for two years longer. The Union army continued holding the country north of the Arkansas River and the Confederates, south. Raids matched counter-raids with no permanent gains to either side and much loss to both. The Confederate Indians took refuge on the Red River where they suffered as great hardships as had been endured by the refugees in Kansas at the beginning of the war. Sherman's path to the sea presented a scene of no greater destruction and desolation than Indian Territory after the Civil War.

The loyal bands returned to their homes in the summer of 1862, 1863 and again in 1864 and made crops only to have them destroyed by raiders from the south. The suffering was intense on both sides. Parched corn came to be a luxury during the winter months and wild fruits and berries sustained life in the summer. All the cattle and horses were appropriated by the army, and with the able-bodied men in the service of one faction or the other, the women and children were left to shift for themselves.

${ }^{24}$ Journal of the Council for 1863 in Manuscript, Tahlequah, Oklahoma. 
Probably no part of the United or disunited States suffered such havoc as did the Indian Territory during this period. After the besom of war had swept, first north and then south, hardly a home was left standing. The country presented a tragic picture of blackened chimneys rising from the ruins of charred homesteads, of unfenced fields overgrown with weeds and brambles, and of a destitute population, reduced to the very verge of despondency. Thus did the Red Man help pay the price of freedom for the Black. 


\section{CHAPTER XXI}

\section{Reconstruction of the Cherokee Nation}

The fugitive chief of the Cherokees, arriving at Philadelphia in the early winter of 1863, had first to seek a suitable abiding place for his family. This was found in an old colonial house on the south side of Washington square, inherited by Mrs. Ross. ${ }^{1}$ Then hastening to Washington he at once began trying to set himself and his nation right with the United States Government. In spite of intriguing enemies, who, for reasons of their own, did not wish to see the Cherokee reinstated, he secured an interview with the President and stated his case. He claimed that, deserted by their natural protector, his nation had been compelled to seek an alliance with the Confederacy. As soon as the Federal troops came to their rescue the main body of the Cherokees had gladly returned to their allegiance. He believed that they were justified in the course they had pursued because they had been forced into it by the exigencies of the moment. ${ }^{2}$ Notwithstanding the fact that he had thrown the whole weight of his influence and the strength of his resources into the balance of the Confederacy for a few months, his heart, he naïvely assured the President, had always been in the Union. As a matter of fact his heart had never been in the Union nor in the Confederacy. It had never gone beyond the boundaries of the Indian Territory, scarcely beyond those of the Cherokee Nation. He had joined the Confederacy because he saw destruction ahead if he did not. He had tried to make the best of a bad situation. Likewise, his loyalty to the Union was actuated purely by motives of self-preservation. Why should it have been otherwise? Reviewing the history of the last thirty years one fails to find a reason except in the most abstract ethics.

The point of view and logic of the defense were not lost upon Lincoln. With his great breadth of mind and depth of sympathy he could not fail to appreciate, in a measure, the position of the Indian in the war. He was convinced that the

${ }^{1}$ Manuscript in the collection of L. C. Ross, Tahlequah, Oklahoma.

${ }^{2}$ Ross to Lincoln, January, 1863. Ibid. 
chief had some show of justice on his side and promised a thorough examination of the case as soon as circumstances would permit. ${ }^{3}$ With the assurance that his nation would be fairly dealt with in due time, Mr. Ross was compelled to content himself for the present.

The promised investigation did not materialize, however, and the end of the war found the Cherokees on a precarious footing at Washington. If they had cherished any hope of escaping the rigors of reconstruction they were soon to be undeceived. Politicians were not slow to see the White Man's opportunity in the Red Man's extremity. It was a rare chance of securing valuable lands for nothing and one not to be neglected. One of the first statements of this policy is to be found in the early summer of 1864 in a letter of Colonel W. A. Phillips, then Commandant at Fort Gibson. The occasion was a convention held by the Choctaws, at New Hope the preceding March, with a view to profiting by the President's Amnesty Proclamation. They had appointed a provisional governor ${ }^{4}$ for their nation and sent a delegate to Washington. Colonel Phillips, upon hearing of this, forwarded a protest to the National Capital stating that the tribe was still in a state of rebellion and advising that no terms be made until a more secure basis had been reached. The illuminating suggestion was added, that the situation furnished a good excuse for reducing the great Indian domains to mere reserves, and for opening up land for settlement, an opportunity which the country could not afford to neglect. ${ }^{5}$

A word to the wise was sufficient. The next year found the policy suggested by Colonel Phillips fairly well outlined by the Indian Department. Presently rumors reached Indian Territory that the treaty rights of the Indians were considered abrogated and in the renewal of friendly relations the tribes would be completely at the mercy of the United States in consequence of their part in the rebellion. The people of the

${ }^{3}$ Correspondence between Lincoln and Ross, in Ross Manuscripts.

4 Thomas Edwards.

${ }^{5}$ Abel, A. H., The Indians in the Civil War, American Historical Review, Vol. 15, p. 295. 
Five Tribes, having much to lose in such a case, were particularly uneasy and desirous of renewing their treaty relations on the best terms obtainable. As a first step towards this end a grand council of all the Southern Indians was called to meet at Camp Napolian, Chattahomha, May 24, 1865. Representatives of fifteen tribes are said to have been present. ${ }^{6}$ A solemn league of peace and friendship was entered into, resolutions were drawn up expressing their purpose and wishes and delegates, representing each of the tribes, were appointed to go to Washington for the purpose of conferring with the Federal Government on the subject of new treaties. Hearing of this action of the Indians and thinking it wiser to arrange treaties with them in their own country, the President appointed a commission to meet their representative at some place in the Indian Territory.

The Choctaws again took the initiative. Their chief, Peter Pytchlyn, a conservative, well educated man, who had never been a bitter partisan in the war, ${ }^{7}$ sent out a call for a general conference with the commissioners to be held at Armstrong Academy, September 1. His proclamation, after describing the existing conditions and urging all to send representatives to the conference, closes with the following significant sentences: "It therefore becomes us as a brave people to forget and lay aside our prejudices and prove ourselves equal to the occasion. Let reason obtain, now that the sway of passion has passed, and let us meet in council, with a proper spirit, to renew our former relations with the United States government."

The Grand Council which was convened at Fort Smith, instead of at Armstrong Academy, to suit the convenience of the commissioners, proved to be a notable one indeed. The Federal Government was represented by Elijah Sells, Superintendent of the Southern Indians, Thomas Wister, a prominent Quaker of Pennsylvania, Major General W. S. Harvey of the United States Army, Colonel Ely S. Parker, an educated Iro-

- Cherokees, Choctaws, Chickasaws, Creeks, Seminoles, Caddoes, Cheyennes, Araphaoes, Osages, Kiawas, Lepans, Northern Osages and Anadockies. Report of Commissioner of Indian Affairs, 1865, p. 295.

'Abbot, History and Civics of Oklahoma, p. 127.

${ }^{8}$ Thoburn and Holcomb, History of Oklahoma, p. 100. 
quois Indian who had served as a member of General Grant's staff during the war, and D. N. Cooley, president of the commission. Milton W. Reynolds, who was present as a representative of the New York Tribune, declared that the delegates of the Indian tribes were no less brilliant and conspicuous than the representatives of the Federal Government, but if the truth were told, so far as power of expression, knowledge of Indian treaties and real oratory were concerned, they had a decided advantage. $^{9}$ Governor Colbert of the Chickasaws, Colonel Pytchlyn of the Choctaws and Chief Ross of the Cherokees were regarded as men of ablity, education and good breeding whereever they were known. But the most gifted and powerful in eloquence of all the Indian representatives was Colonel E. C. Boudinot, son of Elias Boudinot ${ }^{10}$ and nephew of Stand Watie, just out of the Confederate Congress at Richmond where he had served as a delegate of the Southern Cherokees. With his impassioned eloquence and distinguished appearance he was one of the most pronounced figures in the convention. ${ }^{11}$ There was present also a large delegation from Kansas, composed of lawyers and lobbyists, who came for the purpose of insisting that room be made in Indian Territory for the Indians in Kansas whose reservations covered some of the best lands in the southern part of the state. In addition to all these was a multitude of men, women and children from the various tribes. Their picturesque camps on the outskirts of the town must have interested even if their pathetic poverty failed to touch the sympathy of the most hardened war veteran present.

The council was called to order on September $8 .^{12}$ After the blessings of the Great Spirit had been invoked upon the deliberations in an earnest prayer by Reverend Lewis Downing, second chief of the Cherokee Nation, the objects of the meeting were stated by the chairman, Commissioner Cooley, who in-

- Rock, Marion T., Illustrated History of Oklahoma, pp. 8-9. Mr. Reynolds wrote a reminiscence of the meeting several years after it took place.

${ }^{10}$ Killed at Park Hill, 1839.

${ }^{11}$ Rock, Illustrated History of Oklahoma, p. 9.

12 The proceedings of the Conference are given in full in the Report of the Commissioner of Indian Affairs, 1865, pp. 299-336. 
formed the Indians that since most of them had violated their treaty obligations to the United States by entering into diplomatic relations with the Confederacy they had forfeited all annuities and interests in lands in Indian Territory. However, the long-suffering President was willing to hear his erring children in extenuation of their great crime, and to make treaties with such nations as were willing to be at peace among themselves and with the United States. There were certain general terms on which their relations might be restored: the opposing factions of each tribe must enter into a treaty of amity and peace among themselves, between each other as tribes, and with the United States; the tribes settled in the Indian country should bind themselves, at the call of the United States authorities, to assist in keeping peace among the wild tribes of the plains; slavery should be abolished and measures taken to incorporate the slaves into the several tribes on an equal footing with the original members, or they should otherwise suitably provide for them; slavery or involuntary servitude should never exist in any tribe or nation except in the punishment of crime; a part of the lands hitherto owned and occupied by the Indians must be set apart for the friendly Indians in Kansas and elsewhere on such terms as might be agreed upon, or fixed by the government. ${ }^{13}$

Full delegations from some of the tribes had not yet arrived but the next few days were taken up by those present in submitting credentials, discussing the limitations placed upon them by their instructions and in explaining how and why they had been induced to sign treaties with the Confederate Government.

According to the report of the chairman of the Council one of the most interesting of these explanations was a paper from the loyal Cherokees pleading "not guilty" to the charge of being rebels in consequence of the treaty concluded with the southern states. This brought forth a lengthy reply from Commissioner Cooley in which he reviewed the history of the Cherokees in the Civil War, showing that they had been guilty of open defection from the Union, and fixing the blame upon a

${ }^{13}$ Report of Commissioner of Indian Affairs, 1865, p. 299. 
few bad men, chief of whom was John Ross. That the majority of the nation had been, and still were, loyal at heart he admitted. If they wished to remove the stigma and the disability placed upon them by a few wicked renegades they would be given an opportunity to do so by submitting to the terms proposed by the United States. All forfeitures and penalties against those who had not voluntarily aided the enemy would be remitted, even if they were found necessary in other cases.

After four days of preliminary discussion by delegations from several different tribes, a draft of a preliminary treaty based upon the principles contained in the opening remarks of the commissioner was presented to the convention. 'The loyal Cherokees expressed their willingness to sign the agreement if they did not acknowledge that they had forfeited their rights and annuities as set forth in the preamble, but their signatures must be made under the statement that "we, the loyal delegation, acknowledge the execution of the treaty of October 7, 1861, but we solemnly declare that the execution was procured by the coercion of the rebel army."14 The Southern Cherokees objected to the treaty on the ground that it would be neither for the benefit of the emancipated negro, nor for that of the Indian, to incorporate the former into the tribe on an equal footing with its original members. They also objected to consolidating all the tribes of Indian Territory under one government because of the many incongruous and irreconcilable members which no power could bring into a semblance of assimilation. They further asked that there might be an equitable division of their country by the United States, as they believed that there was no way of restoring peace and harmony between the still warring factions.

Mr. Ross was still in the east when plans for the council were arranged. Realizing how desirable it was for him to be on hand to defend himself and his nation, he set out for the west as soon as he was able. The Cherokee National Council was in session when he reached Tahlequah the first of September, and he lingered a few days before proceeding to Fort Smith. It was not until the thirteenth that he arrived at the ${ }^{14}$ Ibid, p. 336. 
camp of his delegation on the other side of the river from the place of meeting. Fatigued from the long and wearisome journey the aged chief did not show himself at the council grounds until the afternoon of the following day and after the preliminary treaty had been submitted.

The meeting had been in session several days and the factional differences between the loyal and the Southern Cherokees had been given time to show themselves. Added to the ancient feuds, which still rankled, was the confiscation act passed by the loyal Council of 1863, which prevented the southern part of the tribe, numbering about six thousand, from returning home. They were at this time living in great destitution upon the Red River and their representatives at Fort Smith were anxious to secure assurance from the loyal delegation that the law would be repealed and their people reinstated in their homes. This promise could not be secured, the delegation claiming that they did not have the power to bind their Council to any policy of action. Considerable disappointment and irritation naturally resulted, and as usual, Mr. Ross was conveniently made the scapegoat by the commissioners, who had made up their minds before his arrival to refuse to recognize his official position.

To the surprise of the Cherokee delegation, therefore, at the first session which Chief Ross attended Commissioner Cooley read an announcement to the assembled Indians stating that the commissioners refused, in any way or manner, to recognize Mr. Ross as chief of the Cherokees, giving as their reason that he was considered by them an enemy to the United States, that he was disposed to breed discord among his own people and between them and the United States; that he counseled the Creeks against signing the treaty then under consideration; and finally that he did not represent the will and the wishes of the loyal Cherokees. ${ }^{15}$

If they expected the Indians to meekly acquiesce in this high-handed policy they did not appreciate the character of the men with whom they were dealing. A people naturally so

${ }^{15}$ The Cherokee Question, p. 4. Report of Commissioner of Indian Affairs, 1865, p. 306 ; Ibid, p. 308. 
tenacious of their right to life and liberty could not well have been expected to yield up their autonomy at the drop of the hat after all the years of struggle to maintain it, nor would they permit such a stigma to rest upon a man who had served them so faithfully and so long. A solemn protest was promptly filed by a committee from the delegation of loyal Cherokees in which they claimed, putting it mildly, that the act of the commissioners was based on erroneous information; that Mr. Ross was not the pretended chief of the Cherokee Nation but the principal chief in law and fact, having been duly elected to that position by the qualified voters, in accordance with the provisions of the constitution; that for the past three years he had been the authorized delegate to Washington, and the recognized head of the Cherokee Nation. There had been no action on his part during this time which impugned his loyalty to the United States or his fidelity to the Cherokee Nation. As to his course in the Civil War he had remained loyal long after the tribes and states in his vicinity had abjured their allegiance to the Union and after all protection had been withdrawn by the United States, yielding to the Confederacy only when further resistance threatened the entire destruction of his people. They denied that he had used his influence since his arrival at the Council to prevent the Cherokees or the Creeks from signing the proposed treaty. The discussions following, in which E. C. Boudinot took a brilliant part, served only to widen the breach between the two factions, and between the loyal Cherokees and the commissioners. The restoration of friendly relations between them appeared yet a long way off, and all hope of a treaty agreement at this time was given up.

The success of the Fort Smith Council from the point of view of all concerned was only partial, due to the fact that the terms offered by the United States were not altogether acceptable to the Indians, and partly to the fact that several of the delegations, including the Cherokees, had not been notified that new treaties with them were desired by the government, and they had therefore not been properly authorized to make treaties relinquishing any of their lands for the use of friendly tribes in Kansas. The Cherokees refused to enter into any negotiation 
for such a treaty until their Council should appoint a commission with the proper authority for the purpose. ${ }^{16}$ The meeting therefore came to an end with nothing definite accomplished, so far as the Cherokees were concerned, except a preliminary treaty of peace and-amity as a basis for future action, and an agreement to send a delegation with proper authority to treat at Washington, probably the next December.

The winter of 1866 was a dreary one indeed for the whole tribe. The condition of those on the Red River could not be expected to improve as long as they remained there. Those who returned to their desolate nation fared little better. There were few churches, no schools, no cultivated fields, except here and there a little corn patch in some secluded place cultivated by women and children and the old men. The mills had been destroyed so that the primitive mortar and pestle had to be depended upon for what little meal was used. Fortunate indeed were those who had all the boiled corn or hominy they wanted. Flour at forty dollars a barrel was prohibitive. Even salt, which before the war had been manufactured in considerable quantities on the Grand Saline, was at a premium, the salt works, which had been in use for over thirty years, having gone the way of other improvements. Hoes, plows, axes, all implements so necessary to an agricultural community, were sold at prohibitive rates, and the necessary price of the commonest necessities was very hard to get. It was high time something should be done to restore to the people their national pride and to furnish them an incentive, as well as the means, for work.

This was plainly no time for haggling and hair-splitting. Yet when the delegations met in Washington at the beginning of the year their early discussions gave little promise of prompt adjustment of the difficulties by means of a treaty. Both sides had engaged strong legal counsel and the discussions were ably conducted. Draft after draft of a treaty was drawn up, only to be rejected by one or both parties. The Southern Cherokees, feeling that it would be unsafe to return home with the Ross party in full possession of the government and the confisca-

${ }^{16}$ The Cherokee Question, p. 3. 
tion laws in force, demanded as the only hope for their peace and well-being a division of the Cherokee lands and annuities in proportion to the numbers of each party. ${ }^{17} \mathrm{~A}$ prompt protest was filed by the National party which had always opposed any scheme which threatened their national integrity. They suggested instead that one district ${ }^{18}$ of the nation be set aside for two years for the sole occupation of the Southern party, pending a final settlement of the controversy. Of course this plan was wholly unacceptable to the opposition because of the smallness of the district and for other very good reasons.

Weeks and months of bickering and wire-pulling followed, each party suspicious of the other, and both of the Federal Government, which, determined to secure land upon which to colonize Indian tribes in Kansas, was not blind to its opportunity of driving a keen bargain at the expense of the discordant factions. Despairing of arranging terms with the loyal Cherokees, the commissioners at last determined to treat with the Southern party. Finally on June 19, a treaty was concluded with them providing that a certain part of the Cherokee Nation should be set apart for their exclusive use. They in turn agreed to sell to the United States a part of the national domain. The treaty was not laid before the Senate but used as a sort of moral suasion on the Nationals, who, after another month of discussion, themselves came to terms and signed a treaty on July 19. At best this treaty was a three-cornered compromise which pleased nobody, but was recognized by all as the best that could be obtained under the circumstances. The Federal Government, as usual, came out the greatest gainer. The treaty provided for the repudiation of the alliance with the Confederacy; declared amnesty for all past offenses; repealed the confiscation laws; allowed 160 acres of land to every freedman; agreed to the establishment of a United States Court in the Indian Territory, and the settlement of friendly Indians on unoccupied lands of the Cherokees. These, with some articles of minor importance, constituted the treaty of $1866 .^{19}$

\footnotetext{
${ }^{17}$ Report of Commissioner of Indian Affairs, 1866, p. 67.

${ }^{18}$ Canadian district.

${ }^{10} 14$ U. S. Statutes at Large, p. 799.
} 
Chief Ross, though much broken in health, headed his delegation as he had done for almost forty years. Before the final draft of the treaty was arranged he became too ill to attend the deliberations of the delegation. Realizing that his end was near, the commissioners, at the suggestion of the Secretary of the Interior, repealed their decree of the previous year deposing him from the chieftainship of the Cherokees on the ground that the reason which rendered that action necessary no longer existed. Just at sunset on August first, he quietly and peacefully passed away.

When news of his death reached the Cherokee Nation, there was sincere mourning among a large portion of his people, both full-bloods and the mixed element who realized that they had lost in their venerable chief a warm friend and an able champion. By act of the National Council, his body was taken to Park Hill and interred with fitting ceremony in the cemetery near his old home. When the National Council convened in October it passed a resolution and placed upon the records a memorial in which his service to his people and their love and confidence toward him were ably expressed. It claims justly that his long career, passed in the constant service of his people, "furnishes an instance of confidence on their part and fidelity on his which had never been surpassed in history." $" 20$

That there is another side to Mr. Ross's reputation, those who have followed this story of his life need not be reminded. By his enemies he was regarded in a very different light from that in which he appeared to his friends. Fond of place and power, ambitious for his own immediate family, dishonest in the use of the Cherokee national funds, severe and partial in the administration of justice, crafty and unscrupulous, trimming his sails to every political breeze,- -these are some of the charges brought against him.

Most of these charges were made by prejudiced persons not competent to judge the man fairly, and are therefore not to be considered seriously. Some of them are perhaps true in a sense. In the light of later events it is evident that he made

${ }^{20}$ Cherokee National Mss. Records, Tahlequah, Oklahoma. 
mistakes in his policy of government. Yet they were not mistakes of a small man, but of a great one. If he erred it was on the side of zeal for a cause which he thought to be right. That he was a political trimmer is an accusation that needs stronger proof than has yet been brought to light, while the accusation itself can be easily accounted for without discredit to Mr. Ross. To understand him it must not be forgotten that he was first, last and always a Cherokee Indian, a citizen of the Cherokee Nation which was to him a sovereign, independent nation. His consuming desire and purpose were to serve and protect to the best of his ability this nation at whose head he stood so proudly and staunchly for many years. To him its welfare and its claims were paramount. $\mathrm{He}$ had no other patriotism, a fact which can be understood and appreciated fully, perhaps, only by those who have lived under conditions similar to those under which he lived and have possessed sentiments and attachments akin to his.

The interests of the full-blood Indians were his first care. The Cherokees have since had chiefs who were patriotic and incorruptible, men of whom any group of people might justly be proud. But they have never had a chief who so guarded the interests of the helpless and gave them preference over the stronger mixed-blood population. And who has needed a strong and sincere friend more than the full-blood? The Cherokees can boast of better educated men than John Ross, more eloquent orators, men of greater literary skill, of higher legal talent. But they have yet to produce a statesman of greater all-round ability, of more strength of character, of greater devotion to his tribe than this Scotch Cherokee Christian gentleman whose long dramatic career came to a close well-nigh half a century ago, marking the end of a most important period of Cherokee history. 


\section{BIBLIOGRAPHY}

\section{SOURCES}

Acts of the General Assembly of the State of Georgia, 1827-1837.

Adams, John Quincy, Memoirs, Edited by Charles Frances Adams.

American State Papers, Indian Affairs, Volumes I and II.

Annals of Congress, 1789-1824.

Annual Cyclopedia, 1861.

Annual Report of Board of Education of the Cherokee Nation for 1887, containing a report of Commissioner Paine for 1845. Pamphlet.

Bartram, William, Travels Through North and South Carolina, Georgia, East and West Florida, the Cherokee Country, the Creek Confederacy and the Land of the Choctaws, 1773-1778.

Cherokee National Records; Manuscripts, at Tahlequah, Oklahoma.

Cherokee Nation, Laws of, Adopted by the Council at various periods, Knoxville, 1826.

Cherokee Phoenix, 'The, 1828-1834, The Chicago Historical Society.

Cherokee Question, The; A pamphlet report of the Commissioner of Indian A ffairs to the President on the Question of Cherokee Loyalty in the Civil War. It also contains Albert Pike's letter of February 17, 1866, and various letters and papers on the Civil War in the Cherokee Country.

Cherokee Treaties, 1866.

Confederate Statutes at Large, The.

Confidential letter of P. M. Butler to T. Hartley Crawford, Indian Commisioner, March 4, 1842. On file in Indian Office, Washington, D. C.

Congressional Documents, Serial Numbers: 27, 64, 86, 114, 115, 122, 133, $165,171,173,184,186,187,208,217,286,273,283,292,311,315,318$, $325,328,329,330,340,342,348,359,365,366,368,404,411,420$, 425, $428,429,433,434,443,446,451,457,474,476,477,483,485,490,493$, $495,511,521,523,526,529,531,544,547,554,565,576,618,652,658$, $673,690,710,723,743,751,783,859,914,965,1070,1232$.

Congressional Globe, Sessions of Congress from the 23rd to the 31st.

Eyeretts, Jeremiah, Speeches on the Passage of the Bill for the Removal of the Indians,-One Volume, Boston and New York, 1830.

Gales and Seaton's Register of Debates in Congress, 13 Volumes, Washington, December, 1824, to March, 1837.

Gentleman of Elvas, the, Hakluyt Society Publications, London, 1851.

Hicks, Elijah, Journal in Manuscript for the year 1837 in the Collection of the Sequoyah Historical Society, Claremore, Okla.

Indian Office Manuscript Records, 1913, containing letter books, report books and many letters, which in the spring of 1913 had not been arranged in order for convenient reference purposes, but are very valuable material on the subject nevertheless. A description of them is given in Van Tyne and Leland's Guide to American Archives, pp. 205-209, and in Miss Abel's Bibliographical Guide in Annual Report of American Historical Association, 1906, Vol. I, pp. 413-438.

Irving, Washington, Tour of the Prairies.

Jefferson's Works, Library Edition.

Lanman, Letters of the Allegheny Mountains.

Laws of the Cherokee Nation, Printed in English and Cherokee. 
Missionary Herald, Ayer Collection, Newberry Library, Chicago.

Moore's Rebellion Records, Vols. II and VI.

Morse, J., Report of the Secretary of War on Indian Affairs, 1822.

Niles' Register, Numbers 4, 6, 14, 16, 26, 36, 37, 39, 40, 41, 42.

Nuttall, Journal of Travels in the Arkansas Territory (Phil., 1829).

Official Records of the War of the Rebellion, Series I, Vols. I, II, III, VIII and XIII.

Payne Manuscripts, nine volumes, containing the Cherokee official records before 1838; letters of Missionaries on the condition of the Indians before 1830 and during removal; letters of Cherokee children in the Mission Schools to philanthropic people in the north; traditions and myths as related to John Howard Payne by prominent members of the tribe in 1836.

Philadelphia North American, 1863, Library of the University of Pennsylvania.

Richardson's Messages and Papers of the Confederacy, containing diplomatic correspondence between the Confederate and the Cherokee governments, 1861-1865.

Richardson's Messages and Papers of the Presidents, 1789-1897, ten volumes.

Ross Manuscripts, part of which belong to Mr. Robert L. Ross and the remainder to Mr. L. C. Ross, both of Tahlequah, Oklahoma. They consist of a mass of unorganized material very valuable to those interested in the subject of Cherokee history.

Supreme Court Reports: Cherokee Nation vs. Georgia, 5 Peters, p. 1; Worcester vs. Georgia, 6 Peters, p. 516.

Swain, James B., The Life and Speeches of Henry Clay.

United States Statutes at Large, Volumes IV, VII and IX.

Washburn, Cephas, Reminiscences of the Indians, 1869.

\section{SECONDARY AUTHORITIES}

Abel, A. H., The Indians in the Civil War. American Hist. Review, Vol. XV.

Abel, A. H., History of Events Resulting in Indian Consolidation West of the Mississippi.

Adair, J., History of the American Indians.

Bancroft, History of the United States, Vol. II.

Benton, Thomas H., Thirty Years' View.

Dodd, William E., Jefferson Davis.

Drake, S. G., Biography and History of the Indians in North America, 1857.

Drake, S. G., Early History of Georgia, embracing the Embassy of Sir Alexander Cummings to the Country of the Cherokees, 1872.

Garrison, William Lloyd, Life of, as told by his children, four volumes, New York, 1885-9. Contains references to Garrison's Indian policy and to Georgia's treatment of the Cherokees.

Gilmer, George R., Georgians, The, 1855.

Greeley, Horace, The American Conflict.

Gude, Mary B., Georgia and the Cherokees.

Hart, A. B., The Formation of the Union.

Haywood, J., Natural and Aboriginal History of Tennessee, two volumes, 1823.

Hewat, A., Historical Account of the Rise and Progress of the Colonies of South Carolina and Georgia. 
Jackson, Helen Hunt, A Century of Dishonor, 1881.

Kennedy, John Pendleton, Memoirs and Life of William Wirt, two volumes. Vol. II, Chapters XV, XVII and XIX are useful for the study of the Cherokee Case.

Lumpkin, Wilson, Removal of the Cherokee Indians, 1827, 1828, two volumes, 1908.

McKenney and Hall, History of Indian Tribes of North America, 1855, $1858,1870$.

Martin, History of North Carolina.

Mooney, James, Myths of the Cherokees. 19th Annual Report of Bureau American Ethnology, 1897, 1898, Part I.

Parker, T. V., The Cherokee Indians, 1907.

Phillips, U. B., Georgia and States' Rights; Annual Report of American Historical Association, 1901, Volume II.

Pickett, A. J., History of Alabama.

Ramsey, J. J. M., Annals of Tennessee, 1853.

Ross, Mrs. W. P., Life and Times of W. P. Ross, 1893.

Royce, C. C., The Cherokee Nation of Indians, 5th Annual Report of Bureau of Ethnology, 1883-4.

Sargent, Epes, Life and Public Services of Henry Clay, New York, 1848.

Scott, Nancy M., A Memoir of Hugh Lawson White, 1856. Includes selections from his speeches, some of which contain criticisms of Benjamin F. Curry and Cherokee Removal.

Starr, Emmett, The Cherokees West.

Thompson, Augustus Charles, Moravian Missions.

Thwaites, The Colonies, 1492-1750.

White, Rev. George, Historical Collections of Georgia.

Wilson, Division and Reunion.

Von Holst, Constitutional History of the United States. 


\section{RETURN TO: CIRCULATION DEPARTMENT 198 Main Stacks}

\begin{tabular}{cc|l|l}
\hline $\begin{array}{c}\text { LOAN PERIOD } \\
\text { Home Use }\end{array}$ & 2 & 3 \\
\hline 4 & 5 & 6 \\
\hline
\end{tabular}

ALL BOOKS MAY BE RECALLED AFTER 7 DAYS.

Renewals and Recharges may be made 4 days prior to the due date. Books may be renewed by calling 642-3405.

DUE AS STAMPED BELOW.

\begin{tabular}{l|l|l}
\hline SENFONHL & & \\
MAY 18 2001 & & \\
U. C. BERKELEY & & \\
\hline & & \\
\hline & & \\
\hline & & \\
\hline FORM NO. DD6 & BNIVERSITY OF CALIFORNIA, BERKELEY \\
\hline
\end{tabular}




\section{U.C. BERKELEY LIBRARIES}

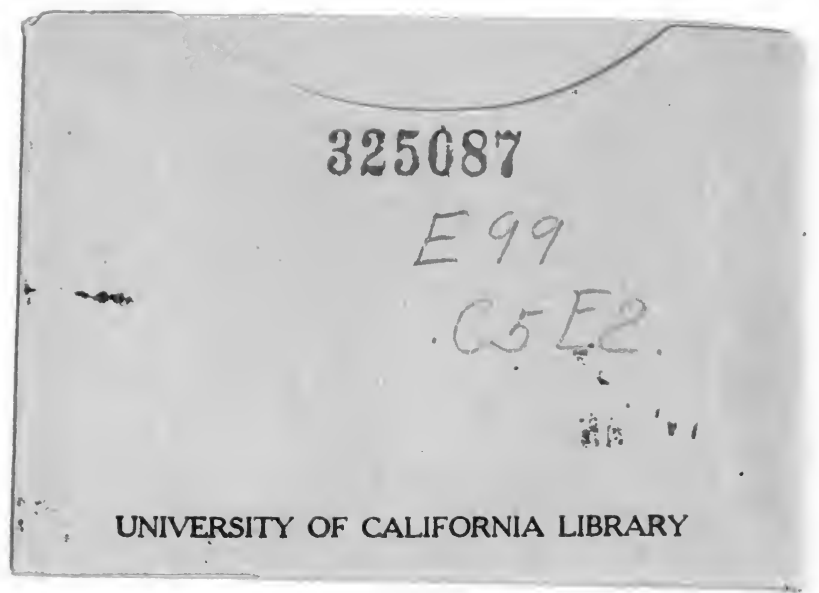




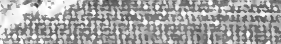

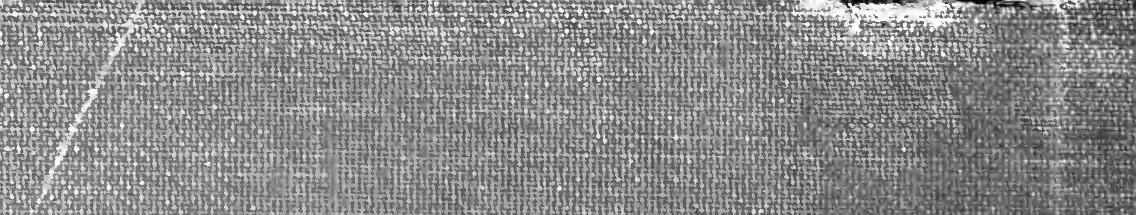

H.

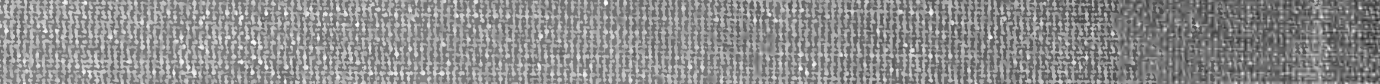
H.

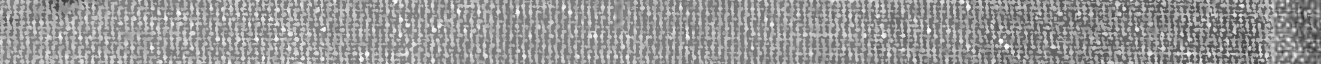

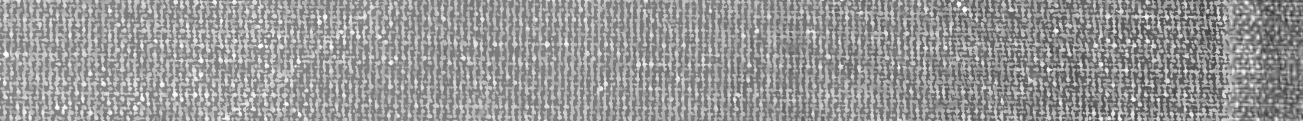

m.t.

A III

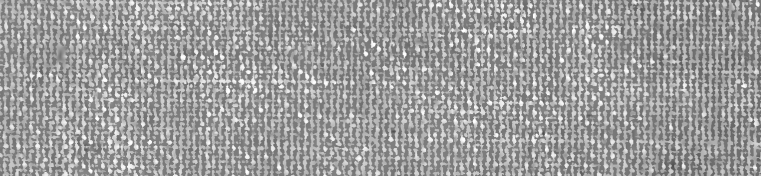

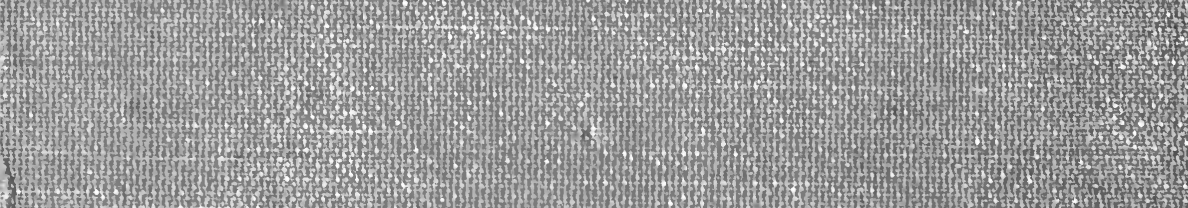

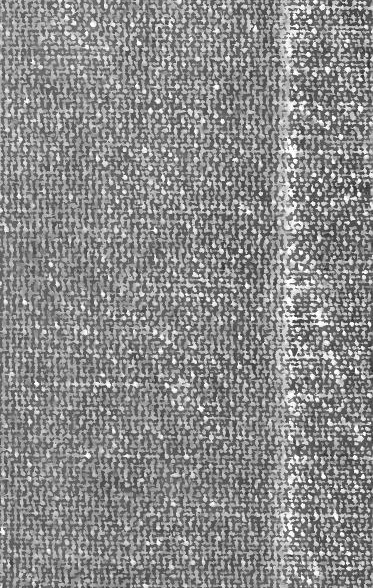

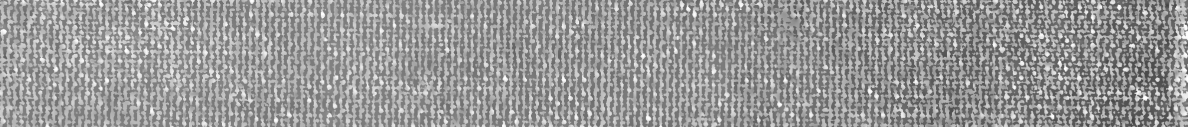
mom 